\title{
GEOLOGY AND GEOCHRONOLOGY OF THE HEALY QUADRANGLE, SOUTH-CENTRAL ALASKA
}

\author{
By Béla Csejtey, Jr., Michael W. Mullen, Dennis P. \\ Cox, and Gary D. Stricker
}

\section{INTRODUCTION}

The Healy quadrangle is underlain by a wide variety of sedimentary, volcanic, and plutonic rocks, ranging in age from Precambrian(?) to Holocene. There are fifty-five map units on the geologic map. All the pre-Cenozoic rocks are intensely deformed, mainly by thrusting and folding, and most of them underwent at least one period of low- to medium-grade regional metamorphism. This deformation is the result of the mid-Cretaceous collision and subsequent obduction of the northward-moving Talkeetna superterrane with and onto the Yukon-Tanana and Nixon Fork terranes of the ancient North American Continent. Late Cenozoic deformation, the result of continued northward plate motions, has modified but not substantially altered the geology of the quadrangie.

Geologic mapping of the Healy quadrangle was undertaken between 1978 and 1982 by the U.S. Geological Survey as part of a multidisciplinary effort to assess the mineral-resource potential of the quadrangle. The multidisciplinary effort included geological, geochemical, and geophysical investigations, all carried out under the auspices of the Alaska Mineral Resource Assessment Program (AMRAP). The geologic map and accompanying discussions of this report constitute the first of a series of planned publications presenting the results of these investigations.

To a considerable extent, the geologic map of this report is a compilation and reinterpretation of the work of a number of geologists who, within the past twenty years, in association with a number of geologic research organizations, conducted geologic mapping in the Healy quadrangle. Most of these geologists who were principal investigators are listed in the geologic credit section on sheet 1 of this report. As in the case of any geologically complex area investigated by a number of geologists, a unanimity of opinion among them could not be reached on either all details of the geologic map or larger interpretations. Thus, the geologic map and interpretations of this report primarily reflect the views and opinions of the first two authors and not necessarily those of the others. Geologists with differing opinions and views on the geology of the Healy quadrangle and adjacent regions are encouraged to publish those views in the geologic literature in the hope that a full exposition of the diversity of views on this challenging region of Alaska will contribute to further resolutions of the geologic problems.

\section{ACKNOWLEDGMENTS}

Geologic investigations in the rugged and mountainous Healy quadrangle could not have been completed without the outstanding airmanship and helpful cooperation of the following helicopter pilots: Gary D. Traylor, E. Jerry Carlson, Richard H. Rossiter, Larry Mohler, Ken Rose, and Steve Smith. During fieldwork the invaluable logistical support and hospitality of local residents Jim and Vonnie Grimes and Don and Mary Neumann is greatfully acknowledged. The authors are grateful for the support and cooperation of the National Park Service personnel at Denali National Park and Preserve.

\section{DESCRIPTION OF MAP UNITS ALL AREAS OF HEALY QUADRANGLE SEDIMENTARY AND VOLCANIC ROCKS}

Surficial deposits (Quaternary)-Glacial drift of several ages, including moraines, outwash, and lake deposits; alluvium and colluvium including several landslides, especially along the Alaska Railroad in the Nenana River canyon (Wahrhaftig and Black, 1958). All mainly consist of unconsolidated gravel, sand, silt, and clay; landslides include blocks of bedrock

Thd Hornblende dacite (Pliocene)-Subvolcanic intrusive rocks of Jumbo Dome, in northcentral part of quadrangle. An age determination on basaltic hornblende by the $\mathrm{K}$-Ar method (M.A. Lanphere in Wahrhaftig, $1970 \mathrm{~d})$ yielded a Pliocene age $(2.79 \pm 0.25$ Ma; No. 1, table 1)

Tn Nenana Gravel (Pliocene and Miocene)-Poorly consolidated, buff to reddish-brown, fluvial sequence of pebble- to boulder-conglomerate and coarse-grained sandstone with interbedded mudflow deposits, thin claystone layers, and local thin lignite beds. Sequence is moderately deformed, is over $1,300 \mathrm{~m}$ thick, and occurs mostly along the northern flank of the Alaska Range. Near the mouth of Honolulu Creek, in the southwestern part of the quadrangle, an isolated patch of buffweathering, unfossiliferous and unconsolidated 
pebble- to boulder-conglomerate and coarsegrained sandstone appears to be lithologically very similar to Nenana Gravel to the north (Inyo Ellersieck, oral commun., 1984), and thus is shown on the map as unit Tn?. The Nenana Gravel rests unconformably on rocks as old as the Precambrian(?) and lower Paleozoic pelitic and quartzose schist sequence (Pz€€p). Locally, however, the contact is conformable with the underlying Tertiary coalbearing rocks (unit Tcb; Capps, 1940; Wahrhaftig, 1958). Because of the lack of diagnostic fossils, the age of the Nenana Gravel is uncertain, but it appears to be older, on the basis of regional geologic and geomorphological considerations, than the Pliocene (about $2.79 \mathrm{Ma}$ ) hornblende dacite intrusive rocks of Jumbo Dome (Wahrhaftig, 1970a, 1975, oral commun., 1984). The lower age estimate is provided by the late Miocene age of the underlying Grubstake Formation of the coal-bearing rocks (unit Tcb; Wahrhaftig and others, 1969). Thus, the bulk of the Nenana Gravel is presumably of Pliocene age, but its basal part is considered as old as late Miocene (Capps, 1940; Wahrhaftig, 1970a, 1970d, 1970e, 1975; Wolfe and Tanai, 1980). Deposition of the Nenana Gravel is interpreted to mark a still ongoing late Cenozoic orogenic activity of uplift and relatively minor deformation in south-central Alaska. Present topographic relief of south-central Alaska, including the Alaska Range, is the result of this orogenic activity (Capps, 1940; Wahrhaftig, 1970a, 1975)

Coal-bearing rocks (Miocene to Eocene)-Unit mostly comprises, in ascending order, the Healy Creek, Sanctuary, Suntrana, Lignite Creek, and Grubstake Formations of the Nenana coal field in the northern part of the quadrangie, consisting of terrestrial rocks of late Eocene and early to late Miocene age (Capps, 1940; Wahrhaftig and others, 1969; Wahrhaftig, 1970b, 1970c, 1970d, 1970e; Inyo Ellersieck, oral commun., 1983; present age assignments as revised by J.A. Wolfe, oral commun., 1984). The unit also includes the Oligocene or Miocene coal-beaning rocks between Sable Pass and Polychrome Pass (Gilbert and Redman, 1975) and the coalbearing deposits of Oligocene age (J.A. Wolfe, oral commun., 1984) at the Dunkle Mine along Costello Creek in the southwest part of the quadrangle (Wahrhaftig, 1944). Provisionally correlated with the unit are the scattered exposures of unfossiliferous, lignitebearing, poorly consolidated sedimentary rocks near Broad Pass Station on the Alaska Railroad (Hopkins, 1951). According to J.A. Wolfe (oral commun., 1984), the lower part of the Healy Creek Formation, of areally limited extent and containing the so-called Rex Creek flora, is not of late Oligocene age, as previously reported in Wahrhaftig and others (1969), but is Eocene in age.

The coal-bearing rocks comprise terrestrial cyclic sequences, in varying proportions, of siltstone, claystone, mudstone, shale, generally crossbedded and pebbly sandstone, both arkosic and quartz-rich, subbituminous coal and lignite, and minor amounts of dominantly quartz- and chert-pebble conglomerate. All of these rocks are characteristically poorly consolidated. More detailed lithologic de scriptions of the coal-bearing rocks can be found in Wahrhaftig (1944), Wahrhaftig and others (1969), and Hopkins (1951). Available plant fossil data for the coal-bearing rocks in the quadrangle are summarized (Nos, 1-3, table 2)

The thickness of the coal-bearing rocks varies greatly as a result of their deposition on an irregular surface of moderate relief, lateral facies changes, and pre-Nenana Gravel erosion. In the Nenana coal field, some of the individual formations comprising the coalbearing rocks may reach maximum thicknesses of over $600 \mathrm{~m}$. However, at any one locality within the Nenana coal field, the total maximum thickness of the coal-bearing rocks does not exceed about $900 \mathrm{~m}$. Some of the coal seams are as much as $20 \mathrm{~m}$ thick, but most have a maximum thickness of only a few meters. Outside the Nenana coal field, the thickness of the coal-bearing rocks is imperfectly known as a result of poor exposures. At the Dunkle Mine, more than 150 $\mathrm{m}$ of coal-bearing rocks are known to be present, and individual coal beds are as much as $2 \mathrm{~m}$ thick.

Current-direction measurements on the coal-bearing rocks within the Nenana coal field (Wahrhaftig and others, 1969) show a generally southward stream-flow pattern, indicating that the site of the present central Alaska Range at that time was a lowland (Wahrhaftig, 1970a, 1975).

The coal within the coal-bearing rocks range in rank from subbituminous to lignite. Heating values determined on coal samples from the Nenana coal field and from the Dunkle Mine generally are between 7,000 and 12,000 Btu (British thermal units; Wahrhaftig, 1951; Wahrhaftig and others, 1951; Barnes, 1967). The Nenana coal field has been and still is a major coal-producer in Alaska. Current mining is by stripping along Healy Creek and Lignite Creek (Sanders, 1975; Parks, 1983). At present, the bulk of the mined coal is used in power plants generating electricity for the city of Fairbanks. In addition to production from 
the Nenana coal field, some coal was produced in the past from the coal-bearing rocks along and near the Alaska Railroad, for example, at the Dunkle Mine until 1954, primarily for heating in communities along the railroad. The economic potential of the coal reserves of the Healy quadrangle is currently under further investigation Poorly consolidated, fluviatile sequence of dark-gray shale, yellowish-gray sandstone, siltstone, and pebble conglomerate of dominantly gray quartz and black chert. Along Jack River these rocks occur in poorly exposed outcrops, containing indeterminate fossil-plant fragments (No. 4, table 2). Although their age is uncertain, their lithologic characteristics suggest that they may be part of the Paleocene to Miocene continental rocks of the quadrangle, possibly correlative with the Eocene to Miocene coal-bearing rocks ( $\mathrm{Tcb}$ )

Volcanic rocks (Oligocene to Paleocene)-These rocks are shown in three separate units on the geologic map: unit Tvv is mostly subaerial flows and associated pyroclastic rocks ranging in composition from rhyolite to basalt; unit Tvif is subvolcanic dikes, sills, and small plugs of felsic composition; and unit Tvim is small subvolcanic bodies and dikes of mafic composition. All three rock units, along with the volcanic rocks subunit of the Cantwell Formation (Tcv), are considered genetically related, and part of the same early Tertiary igneous activity, both plutonic and voicanic, prevalent over large regions of south-central Alaska. In the Healy quadrangle, the plutonic equivalents (Tgr) of the early Tertiary volcanic rocks (Tvv, Tvim, Tvif) range in age from Paleocene to Oligocene, thus the age range of the volcanic rocks is here considered to be the same. Paleomagnetic investigations by Hillhouse and Grommé (1982) and by Hillhouse and others $(1984,1985)$ on the early Tertiary volcanic rocks (Tcv and Tvv), which straddle the Hines Creek and McKinley faults and the Talkeetna thrust in the Healy and Talkeetna Mountains quadrangles, indicate that all these volcanic rocks were formed essentially in their present positions relative to the North American Continent

Trv Volcanic flows, pyroclastic rocks, and subordinate subvolcanic intrusive rocksRocks mapped as part of this unit occur in several various-sized outcrop patches, mostly in the south-central part of the quadrangle, where they appear part of perhaps several, but closely spaced, volcanic centers. Most of these rocks are moderately altered rhyolites and basalts, but rocks of intermediate compositions, namely andesite, dacite and latite, also occur. The rhyolites are generally cryptocrystalline to very fine grained, containing quartz and sanidine phenocrysts. The basalts are generally fine grained, with ophitic to subophitic textures, and their major rock-forming minerals are sodic labradorite and augite. The rhyolite flows, from a few to several tens of meters thick, commonly display columnar jointing. A potassium-argon age determination on sanidine from a rhyolite flow near the East Fork of the Chulitna River yieided an Eocene age of $53.9 \mathrm{Ma}$ (No. 52 , table 1)

Tvim Mafic subvolcanic intrusive rocks-Dikes and small hypabyssal intrusive bodies of dark-gray basalt, diabase, and subordinate andesite. These rocks occur with varying frequency in the westem half of the quadrangle, but only the larger bodies in the northern part of the quadrangle are shown on the geologic map. Potassium-argon age determination from a basalt dike near Sugarloaf Mountain yielded an Eocene age of $54.7 \mathrm{Ma}$ (No. 20, table 1; Bultman, 1972; Sherwood and Craddock, 1979)

Tvif Felsic subvolcanic intrusive rocks-Dikes and small hypabyssal intrusive bodies with subordinate associated pyroclastic rocks, of dominantly tan-colored, aphanitic to very fine grained, locally porphyritic rhyolite, quartz latite, latite, and dacite. These rocks are fairly common throughout the quadrangle, especially in the western half. Four potassiumargon age determinations on felsic rocks near Sugarloaf Mountain yielded early Oligocene ages (Nos. 2-5, table 1; Albanese, 1980). The association of felsic dikes with Paleocene and Eocene volcanic and plutonic rocks in the south-central part of the quadrangle strongly suggests that all the rocks mapped as unit Tvif in the quadrangle range in age from Paleocene to Oligocene

Tfv Fluviatile and subordinate volcanic rocks (Eocene?)-These rocks comprise an intercalated, fluviatile, only slightly deformed sequence of conglomerate, sandstone, siltstone, and mudstone, and a few interlayered, thin flows of basaltic andesite. They unconformably overlie intensely and penetratively deformed Upper Jurassic to lower Upper Cretaceous flysch deposits (KJfl) and are exposed in a narrow band of erosional remnants along ridge tops near the headwaters of the West Fork of the Chulitna River, in the southwestern part of the quadrangle, south of the McKinley fault of the Denali fault system. Although the top of this fluviatile and volcanic sequence is nowhere exposed, a maximum thickness of about 100 to $150 \mathrm{~m}$ still remains.

At the exposures adjacent to the headwaters of Colorado Creek, the conglomerates form 
massive, apparently lenticular layers a few to several tens of meters thick. They are whitish gray and poorly to moderately well cemented, with a chalky sand and clay matrix. Clasts are clay coated, subangular to well rounded, and commonly between 1 and $3 \mathrm{~cm}$ in diameter, although some are as much as $10 \mathrm{~cm}$ across. Most of the clasts consist of white quartz and gray and black chert, but a subordinate amount is composed of gray quartzite, massive as well as laminated limestone, pink finegrained sandstone, light-green and mediumbrown chert, and fine-grained chert conglomerate. The intercalated sandstone, siltstone and shale occur in beds as much as a few meters thick, are gray and brown, and contain carbonized plant fragments.

Hoping to establish a source area or correlation with similar rock types elsewhere in the quadrangle or in Alaska, the limestone clasts were examined by M.W. Mullen for lithology and for microfossil content. Five different rock types were determined and named, using the carbonate classification scheme of Dunham (1962). These rocks are (1) brown, finely crystalline limestone with no recognizable sedimentary structures, (2) a dark brownish-gray, thinly laminated mudstone, (3) dark bluish-gray, thinly laminated mudstone, (4) dark bluish-gray, sandy wackestone containing about 17 percent detrital quartz, and (5) dark bluish-gray, thinly bedded (as thick as $2 \mathrm{~cm}$ ) silty mudstone alternating with dark-gray calcareous shale. The latter two clast types contain distinctive Late Devonian conodont faunas. (For more detailed paleontology, see Nos. 5 and 8 , table 2.) The source of these limestone clasts is still unknown, but they possibly may be from the belt of Paleozoic rocks (units DOs and Is), which crops out about $10 \mathrm{~km}$ to the north, across the McKinley fault, where rocks of Devonian age have been found (Capps, 1932 , 1940; Jones and others, 1983; and Reed, 1961).

One of the carbonized plant fragments from a shale interbed near the headwaters of Colorado Creek (No. 6, table 2) has been identified by J.A. Wolfe (oral commun., 1982. 1984) as Metasequoia occidentalis (Newberry) Chaney, which ranges in age through the Paleocene to early Eocene. This plant fossil is also part of the flora of the Paleocene and fluviatile rocks of the Cantwell Formation to the north of and across the McKinley fault of the Denali fault system (Wolfe and Wahrhaftig, 1970; Wolfe and Tanai, 1980). Based on the occurrence of Metasequoia occidentalis and on lithologic and stratigraphic similarities, the fluviatile and subordinate volcanic rocks unit (Tfv) south of the McKinley fault has been tentatively correlated in the past with the sedimentary rocks subunit of the Cantwell Formation (Tcs) across the fault (Csejtey and others, 1984). However, subsequent reexamination of poorly preserved broad leafed plant fossils from the fluviatile rocks of unit Tfv south of the fault (Nos. 6 and 7, table 2) by J.A. Wolfe (oral commun., 1984). provisionally suggests that these rocks are early Eocene(?) in age, that is, slightly younger than the Paleocene Cantwell Formation, and thus, the two rock sequences are not correlatable,

In view of the lithologic and stratigraphic similarities, the uncertainty of the age determination on the broad-leafed plant fossils, and (or) the possibility of the Cantwell Formation extending in age into the early Eocene, the first author of this report believes that correlation between the two sequences still is a possibility. Reliably proving or disproving the correlation between the two rock sequences would have decisive importance on deciphering the Cenozoic movement history of the Denali fault system, still a controversial problem for interpreting the tectonic evolution of Alaska

Cantwell Formation (Paleocene)-The Cantwell Formation (Eldridge, 1900; Capps, 1940; Wolfe and Wahrhaftig, 1970) consists of an upper volcanic rocks subunit (TcV) and a lower sedimentary rocks subunit (Tcs). The formation occurs in a large, east-trending synclinorium north of the McKinley fault of the Denali fault system

Tcv Volcanic rocks subunit-These rocks comprise an intercalated, moderately deformed sequence of andesite, generally zeolitized basalt, rhyolite and dacite flows, dominantly felsic pyroclastic rocks, a few interbeds of sandstone and carbonaceous mudstone, and a few smail bodies of related subvolcanic intrusive rocks. The volcanic rocks occur in fairly large but discontinuous patches overlying the sedimentary rocks subunit of the Cantwell, mostly at or in the vicinity of Polychrome Pass, Mt. Fellows, and Dick Creek. At many localities, the contact with the underlying sedimentary rocks subunit seems to be conformable, but at some localities it appears to be a slight angular disconformity. The individual flows are from a few meters to several tens of meters thick, many of them are vesicular or amygdaloidal, and the basalts and andesites frequently exhibit columnar jointing. The maximum preserved thickness of the volcanic rocks subunit is over $3.700 \mathrm{~m}$ (Gilbert and others, 1976). Its stratigraphic position, overlying the Paleocene sedimentary rocks subunit of the Cantwell, and potassium-argon age determinations (Nos. 15, 18, 19, and 21- 
25 , table 1) indicate that the volcanic rocks are themselves of Paleocene age. Their lithology and age further indicate that they are an integral part of an early Tertiary volcanic activity and of a great variety of rock types, involving not only the Healy quadrangle but large areas of south-central Alaska as well. Where similar early Tertiary volcanic rocks are not spatially associated with the Cantwell sedimentary rocks, they are shown on the geologic map as units Tvv, Tvif, and Tvim. More detailed lithologic descriptions of the Cantwell volcanic rocks can be found in Hickman (1974) and in Gilbert and others (1976), who have referred to these rocks as the Teklanika Formation

Sedimentary rocks subunit-These rocks consist of a fluviatile, intercalated sequence, in various proportions, of dorninantly polymictic conglomerate, sandstone (including arkose), siltstone, argillite, shale, and a few thin coal beds. Locally, the rocks contain thin flows and related tuff layers of mafic to intermediate composition. The sedimentary rocks subunit is also intruded by numerous dikes and sills ranging in composition from diabase to rhyolite. Bedding usually is massive and regionally lenticular, the rocks are generally moderately well to locally very well indurated and their color commonly ranges from dark to medium gray to dark brown. The maximum preserved thickness of the sedimentary rocks subunit is about $3,000 \mathrm{~m}$, and everywhere, these moderately deformed rocks overlie, with a pronounced angular unconformity, intensely deformed and (or) metamorphosed older rocks of Precambrian(?) to Early Cretaceous age.

The lithology of the conglomerate clasts varies greatly within the outcrop area of the Cantwell Formation, indicating that the clasts were derived from a number of geologically different source areas, and were deposited by a number of river systems. A good example of deposition by different river systerns and accompanying difference in clast composition can be seen around the headwaters area of the Teklanika River. East of the river, the sedimentary rocks subunit of the Cantwell comprises a thick sequence of quartz-rich, fairly well sorted, medium- to dark-gray and dark-brown sandstone, which changes eastward into pebbly sandstone and conglomerate of well-rounded clasts. The clasts consist of white quartz, black to gray chert, white to gray quartzite, dark-gray, finegrained sandstone, black argillite, and subordinate red chert and green chert. Due west and southwest of the river, the Cantwell sedimentary rocks dominantly consist of poorly sorted pebble and cobble conglomerates with well-rounded to subrounded clasts of medium-gray to black, fine-grained sandstone; gray to black argillite; massive or laminated medium- to dark-bluishgray limestone (locally constituting as much as 25 percent of the clasts); black chert; mediumto dark-greenish gray, finely crystalline, altered volcanic rock of mafic to intermediate composition; white quartz; red chert; mediumgray quartzite; and minor green chert. The clasts are contained in a medium- to coarsegrained sandstone matrix of similar composition. The overall color of these conglomerates is dark to medium gray, locally with a greenish hue. The two areas of dissimilar, apparently river-channel conglomerates and sandstones are separated by a zone, 2 to $3 \mathrm{~km}$ wide, of an intercalated, thinly to thickly bedded sequence of shale, siltstone, and fine-grained sandstone, interpreted to be flood-plain deposits.

The limestone clasts in the Cantwell Formation west and southwest of the Teklanika River were derived mainly from unit DOs and from a massive limestone interbed (Is) near the top of that unit. The limestone clasts from unit DOs comprise the following rock types: laminated, dark-gray to black, radiolarian-bearing lime mudstone; mediumgray, bioclastic, lime mudstone and wackestone; medium-gray, intraclastic lime packstone; and cross-laminated, medium-gray, lime bioclastic grainstone (carbonate nomenclature according to Dunham, 1962; also see Nos. 9-11, table 2). The limestone clasts from the massive limestone interbed (Is) consist of light-gray recrystallized limestone and dolomitic limestone. Also, there are a few clasts of calcareous sandstone and sandy to silty limestone, which probably were derived from the sedimentary interbeds of unit kbd.

As mentioned previously, the clast composition of Cantwell conglomerates varies greatly between exposure areas of the formation. In the area just south and east of the Wood River, pebbles of white quartz, black chert, and dark-gray sandstone and argillite predominate, but numerous wellrounded clasts of mica schist and phyllite, which are identical to and thus most probably were derived from the Precambrian(?) and Paleozoic metamorphic rocks north and west of the Wood River, also occur. In the region between Sable and Polychrome Mountains, Cantwell conglomerates generally contain pebbles, locally as much as 10 percent, of impure limestone, which lithologically and in age (determined by conodont studies, see No. 13, table 2) are identical to limestones in the Upper Triassic calcareous sedimentary rocks ( $\mathrm{kCs}$ ) cropping out about $10 \mathrm{~km}$ to the north. 
Many of the dark-gray to black argillite and sandstone clasts, ubiquitous to most Cantwell outcrops, probably were derived from the Upper Jurassic to Lower and (or) Upper Cretaceous flyschlike rocks (KJf, KJfk, KJfI), which occur in large areas of the quadrangle. It appears that while a considerable part of the clasts in the Cantwell sedimentary rocks came from nearby source areas, a large, perhaps the dominating part of the clasts, such as most of the white quartz and black chert, must have originated from still unknown and possibly distant provenances.

Additional lithologic description of the Cantwell Formation can be found in Eldridge (1900), Capps (1940), Wolfe and Wahrhaftig (1970), Decker (1975), and Csejtey and others (1984).

The age of the Cantwell Formation has been determined, on the basis of plant fossils, by Wolfe and Wahrhaftig (1970), and J.A. Wolfe in Hickman (1974), and in Sherwood and Craddock (1979) to be Paleocene (Nos. 12, 14-20, 22, and 23, table 2). However, two small granitic stocks (TKgr) apparently intruding the sedimentary rocks subunit of the Cantwell, one in Riley Creek and the other along the Nenana River, yielded Late Cretaceous potassium-argon ages 178.7 and $71.9 \mathrm{Ma}$, Nos. 17 and 26, respectively, table 1; Hickman, 1974; Hickman and Craddock, 1976; Sherwood and Craddock, 1979). Trying to resolve the conflicting paleobotanical and potassium-argon ages, two possibilities are herein considered to be most likely: (1) perhaps due to excess argon, the potassiumargon age determinations yielded somewhat older than crystallization ages, and (2) the basal part of the sedimentary rocks subunit of the Cantwell may possibly be as old as Late Cretaceous, and thus, the Cantwell Formation may possibly range in age from Late Cretaceous through the Paleocene.

The moderately deformed Cantwell Formation overlies all older rock units with a pronounced angular unconformity; these older rock units, which range in age from Precambrian(?) to Early Cretaceous (see also No. 21, table 2), are all intensely and penetratively deformed. Thus, the age and stratigraphic position of the Cantwell Formation provide an upper age limit for the main phase of the late Mesozoic orogenic deformation of south-central Alaska, at least for the region north of the Denali fault system.

The lithologic and stratigraphic characteristics and the distribution pattern of the sedimentary rocks subunit of the Cantwell, being preserved in a late Cenozoic synclinorium, strongly suggest that the present exposures of Cantwell rocks are only the erosional remnants of formerly much more extensive deposits. These features further suggest deposition in a basin of considerable relief, occupying at least a part of the area of the present central Alaska Range, by a complex network of braided rivers with multiple flow directions

\section{PLUTONIC ROCKS}

Tgr Granitic rocks (Oligocene to Paleocene)-A wide variety of epizonal (Buddington, 1959) granitic rocks, occurring in numerous small- to medium-sized plutons throughout most of the quadrangle. The most cornmon rock types are granite and granodiorite, but tonalite and quartz monzodiorite also occur (granitic rock nomenclature according to IUGS, 1973). The bulk of the granites have alkali-feldspar and plagioclase ratios between 65 and 35 and thus could be called adamellites. Quartz content for most of these rocks is between 30 to 40 modal percent. The color index ranges from 1.4 to 13.7, but commonly it is between 6 and 10 . Grain sizes range from coarse to fine grained and textures from granitic to porphyritic and seriate. Some of the granitic rocks were emplaced at very shallow depths, and thus, could be called hypabyssal intrusive rocks. Where exposed, contacts with the country rocks are always sharp and discordant. The larger plutonic bodies generally have aplitic dikes associated with them, a fine-grained border phase, and a narrow contact aureole. None of the Tertiary granitic rocks display any flow foliation. Potassium-argon age determinations (Nos. 13, 16, 27-32, 47, 49, and 53 , table 1 ) indicate that these rocks range in age from Paleocene to early Oligocene (approximately 59.8 to $36.7 \mathrm{Ma}$ ).

The similar age, composition, and the spatial association of the early Tertiary granitic rocks of the quadrangle with the Tertiary volcanic rocks (Tvv, Tcv, Tvim, and Tvif) strongly suggest that the granites essentially are the deeper seated equivalents of the felsic volcanic rocks, and that both suites of rocks are the products of the same early Tertiary igneous activity that was prevalent in southcentral Alaska

Tgrv Granitic and volcanic rocks, undivided (Oligocene to Paleocene)-Extensive border zone between a large Tertiary granitic pluton (granite and granodionite of unit Tgr) and slightly younger, numerous felsic dikes and small subvolcanic intrusive rocks of unit TVv cutting the granitic rocks, as well as small erosional remnants of rhyolite flows capping the pluton, all in the south-central part of the quadrangle

TKgr Granitic and hypabyssal intrusive rocks (Paleocene? and Late Cretaceous)-This 
unit includes two small plutons of mediumgrained granodiorite, one along Riley Creek and another along the Nena River and numerous smail hypabyssal intrusive bodies of heterogeneous rock types in the area roughly between Lookout Mountain and the Bull River, in the southwest part of the quadrangle.

The two small granodionite plutons appear to intrude the Paleocene Cantwell Formation. However, as already discussed under the Cantwell Formation, potassium-argon age determinations yielded Late Cretaceous ages for them (Nos. 17 and 26, table 1; Hickman, 1974; Hickman and Craddock, 1976; Sherwood and Craddock, 1979). Two possible explanations seem to be most likely: either the two plutons are of Paleocene age, that is, due to perhaps excess argon the potassium-argon age determinations yielded older than crystallization ages, or the basal part of the Cantwell Formation may possibly be as old as Late Cretaceous.

The hypabyssal intrusive rocks in the Lookout Mountain and Bull River area form small stocks, volcanic plugs, intrusive breccia pipes, and dikes. They comprise a wide variety of rock types, namely diorite, andesite, quartz diorite porphyry, phaneritic granite, rhyolite, granite porphyry, rhyolite porphyry, quartz porphyry, coarse-grained quartz monzonite porphyry, aplite, and basalt (Swainbank and others, 1977). Many of the breccia pipes are mineralized (epigenetic vein or vein-disseminate type), and metals commonly present include arsenic, silver, copper, and gold (Hawley and Clark, 1973). Lead, zinc, bismuth, tungsten, and tin are also fairly common, and molybdenum occurs at one locality at Long Creek. The most important of the mineralized breccia pipes is at the Golden Zone Mine, which between 1941 and 1942 , produced 1,581 oz of goid, 8,617 $\mathrm{Oz}$ of silver, 21 tons of copper, and about $3,000 \mathrm{lb}$ of lead (Hawley and Clark, 1974).

Potassium-argon age determinations on mineralized rocks from the Lookout MountainBull River area (Swainbank and others, 1977) yielded Late Cretaceous and possibly Paleocene ages (minimum 58.8 to $70.6 \mathrm{Ma}$, Nos. 54-57, table 1)

\section{TALKEETNA MOUNTAINS QUADRANGLE (PART)}

\section{SEDIMENTARY AND VOLCANIC ROCKS}

Talkeetna superterrane

KR $P_{2}$ Vs Volcanic and sedimentary rocks of Talkeetna superterrane (Triassic and Paleozoic)Appears only in cross sections
NORTHERN, EASTERN, AND SOUTH-CENTRAL AREAS

OF HEALY QUADRANGLE

SEDIMENTARY AND VOLCANIC ROCKS

Yukon-Tanana terrane

Rocks north of Hines Creek fault

Kvb

Basaltic subvolcanic rocks (Late Cretaceous) Dark-gray to black, porphyritic basalt, occurring in a swarm of dikes of limited areal extent just northwest of the headwater area of Dean Creek, in the north-central part of the quadrangle. Only the area of their general extent is shown on the geologic map. The dikes are entirely within the Precambrian(?) and Paleozoic rocks ( $\mathrm{P} z \mathrm{P} \in \mathrm{p}$ and Dmb) of the Yukon-Tanana terrane. A potassium-argon age determination (Sherwood, 1973; Sherwood and Craddock, 1979) yielded a Late Cretaceous age of $79.1 \mathrm{Ma}$ (No. 6, table 1)

MDt Totatlanika Schist (Early Mississippian to Middle Devonian)-The Totatianika Schist crops out in an east-trending belt along the north edge of the quadrangle, along the northem flank of a large, regional antiform. The formation predominantly consists of metavolcanic and metavolcaniclastic rocks, both felsic and mafic in composition, and subordinate amounts of intercalated metasedimentary rocks such as black pelitic schist and, at one locality, a thin interbed of fossiliferous marble (Wahrhaftig, 1968; Gilbert and Bundzen, 1979). The Totatlanika Schist was first mapped and named by Capps (1912). Subsequently, the boundaries of the Totatlanika Schist were revised, and the formation itself was divided into five members by Wahrhaftig (1968). In ascending order, which is either stratigraphic or tectonic, the five members are: Moose Creek Member, Califomia Creek Member, Chute Creek Member, Mystic Creek Member, and Sheep Creek Member. The five members are not shown separately on the geologic map of this report, but their distribution and possible correlative rock types within the Healy quadrangle can be found in Wahrhaftig (1968, $1970 \mathrm{~b}, 1970 \mathrm{c}, 1970 \mathrm{~d}, 1970 \mathrm{e})$. Gilbert and Bundtzen (1976, 1979), and Gilbert (1977). The extension of the Totatlanika Schist into the northwest part of the quadrangle is still somewhat tentative, thus in that region the unit is shown as MDt? on the accompanying geologic map.

The distribution of the major rock types within the Totatlanika Schist is as follows: The Moose Creek, Califomia Creek, and Mystic Creek Mernbers dominantly consist of metarnorphosed felsic volcanic rocks, the Chute Creek Member of basic metavolcanic 
rocks, and the Sheep Creek Member essentially comprises felsic metavolcaniclastic rocks. Black, fine-grained carbonaceous pelitic schists and phyllites occur intercalated with the above rock types, in various proportions, throughout the entire known section of the Totatlanika Schist. At one locality in the Healy D-2 quadrangle (Wahrhaftig, 1968, 1970b), a thin interbed of fossiliferous marble occurs within the Mystic Creek Member (No. 148, table 2).

The felsic metavolcanic rocks comprise varicolored schists, gneisses, and some phyllites consisting of quartz, orthoclase, plagioclase, sericite and (or) muscovite, chlorite, and opaque minerals. Many of these rocks contain blastoporphyritic crystals of quartz, orthoclase, and plagioclase in a fine- to medium-grained matrix. The basic metavolcanic rocks are dark greenish-gray, fine- to medium-grained schists, and phyllites of chlorite, epidote, albite, actinolite, sericite and (or) muscovite, biotite, and opaques. Relict pyroxene and plagioclase are locally present. The volcaniclastic rocks comprise schistose or phyllitic, intercalated fine- to medium-grained metasandstones, siltstones, and purple or pale-green, finegrained metatuffs. The dominant metamorphic minerals are, in various proportions, quartz, feldspar, sericite, and chlorite. At numerous localities, graded bedding and crossbedding are still preserved in the metasandstones. Detailed lithologic descriptions of the Totatlanika Schist are given in Wahrhaftig (1968) and chemical data in Gilbert and Bundtzen (1979).

The metamorphic mineral assemblages suggest that the Totatlanika Schist has been recrystallized into the low-pressure, lowtemperature field of the greenschist metamorphic facies of Turner (1968). The number of metamorphic events affecting these rocks is not known for certain, but probably it is more than one event. Regional considerations suggest that the latest event is about mid-Cretaceous in age (Csejtey and others, 1982).

The structure of the Totatlanika Schist appears to be complex. As in the case of neighboring units of the Yukon-Tanana terrane, the repetitions and the frequent occurrence of strata of the Totatlanika Schist beyond the limits of their assumed stratigraphic positions strongly suggest that most of the lithologic contacts are thrust faults. This seems to be valid not only for the Totatlanika Schist as a whole unit, but for the various members within the formation as well. Thus, the Totatlanika Schist itself may consist of a number of imbricated thrust sheets (Wahrhaftig, 1968). These supposed thrust- fault contacts are parallel to the mineral foliation of the Totatlanika Schist. Because of these structural complexities, the thickness of the Totatlanika Schist can not be reliably determined. The maximum preserved cumulative thickness is over $5,700 \mathrm{~m}$, but at any one area the thickness of the rocks present is considerably less.

The depositional age or rather the depositional age span of the protoliths of the Totatlanika Schist is inadequately known because fossils were found only at one locality in this thick and structurally complex unit. A thin marble interbed within the Mystic Creek Member yielded unidentifiable crinoid columnals and gastropod shell fragments, poorly preserved fragments of the coral Syringopora sp., and more diagnostically, specimens of the conodont Polygnathus sp., and ramiform elements (No. 148, table 2). The coral Syringopora implies either a probable Mississippian or possible Devonian age (Helen Duncan in Wahrhaftig, 1968), and the conodonts indicate a Middle Devonian to Early Mississippian age (A.G. Harris, U.S. Geological Survey, written commun., 1985). On the basis of this evidence, and because of the Late Devonian age of unit Dmb, tentatively correlated with the Chute Creek Member, the Totatlanika Schist is considered in this report to be Middle Devonian to Early Mississippian in age.

As a result of the metamorphism, very few of the original depositional features of the Totatlanika Schist are still preserved. Hence, little can be speculated on the depositional environment of this formation. The mineralogies and chemical data suggest that the bulk of the Totatlanika Schist originated as felsic volcanic rocks. The intercalated carbonaceous black schists, the graded and crossbedded characteristics of the clastic rocks, and the fossiliferous marble interbed indicate deposition in a marine environment. According to Wahrhaftig (1968), the felsic metavolcanic rocks, that is, the bulk of the Totatlanika Schist, were most probably formed as a result of a series of submarine pyroclastic eruptions or ash flows. On the basis of this evidence, and on the basis of tentative lithologic correlation of the Chute Creek and Mystic Creek Members with units Dmb and Dmf, respectively, the protolithic Totatlanika Schist is interpreted to be a continental margin-type deposit.

Dmf Felsic metavolcanic rocks (Late Devonian)-These rocks occur in discontinuous outcrops just north of the Hines Creek fault, along the southern flank of an east-trending regional antiform cored by the pelitic and quartzose schists of unit $P_{z p} \in p$ in the northern part of 
the quadrangle. The unit comprises a massive, thick section of generally dark- to mediumgray, fine- to medium-grained schists and locally phyllites, with relict phenocrysts of quartz, orthoclase, and plagioclase. The phenocrysts are about 0.5 to $2.0 \mathrm{~mm}$ in maximum dimension, and make up about 10 to 25 percent of the rocks by volume. The groundmass consists of quartz, white mica (mostly sericite), potassium feldspar, plagioclase, chlorite, biotite, and opaques and zircon as accessory minerals. The metamorphic grade of these rocks appears to be within the greenschist metamorphic facies of Tumer (1968). Schistosity is moderately or well developed, and commonly bends around the relict phenocrysts. Kink-bending and strain-slip cleavage at high angles to the primary schistosity are common. The overall composition of these rocks, and the generally well preserved forms of the relict phenocrysts, including resorption embayments in quartz phenocrysts with beta-quartz pseudomorphs (Wahrhaftig, 1968; Gilbert and Redman, 1977 ) indicate that the protoliths of the schists and phyllites of unit Dmf were felsic volcanic rocks, ranging from rhyolite to dacite. The original emplacement method of these rocks, whether submarine or subaerial flows or tuffs, or shallow subvolcanic intrusions, is imperfectly known. Their spatial association with marine sedimentary and volcanic rocks (Dmb and Dms) suggest that at least the bulk of them originated as submarine flows and (or) pyroclastic rocks. As a result of structural complexities, the total thickness of these rocks is also imperfectly known, but it must reach at least several hundreds of meters.

The characteristics of the contacts of the felsic metavolcanic rocks unit with adjacent metamorphosed rock units has been obscured by the metamorphism, and hence is poorly known. The irregular outcrop pattern of the feisic metavolcanic rocks unit, its occasional repetitions, and its intercalations with other rock units, which appear to lie stratigraphically below it, strongly suggest that most of the lithologic contacts in fact are thrust faults (Wahrhaftig, 1968). Thus, the structure of these rocks may be much more complex than what can be detected in the field. This appears to be true not only for the felsic metavolcanic rocks unit but for other units of the YukonTanana terrane north of the Hines Creek fault as well (Wahrhaftig, 1968). Most of these presumed and unmapped thrusts appear to have predated or have been contemporaneous with the metamorphism, which is definitely older than the unconformably overlying Paleocene Cantwell Formation.
The age of the felsic metavolcanic rocks is not know for certain, as no fossils of any kind were found in these rocks. At three localities, marble interbeds in the spatially closely associated unit Dmb yielded conodont specimens of Late Devonian and Devonian to Mississippian ages (Sherwood and Craddock, 1979; Nos. 149, 151, and 152, table 2). The Mystic Creek Member of the Totatianika Schist (MDt), which tentatively has been lithologically correlated with the felsic metavolcanic rocks unit (Wahrhaftig, 1968), yielded fossiliferous float from a marble interbed with conodonts and coral fragments of Middle Devonian to Early Mississippian age (No. 148, table 2). On the basis of the above evidence, the felsic metavolcanic rocks unit (Dms) is provisionally considered to be of Late Devonian age

Dmb Metabasalt and subordinate metasedimentary rocks (Late Devonian)-These rocks, like the felsic metavolcanic rocks unit (Dmf), occur in discontinuous exposures on the southern flank of a regional antiform north of the Hines Creek fault, in the northern part of the quadrangle. They comprise an over $600 \mathrm{~m}$ thick, intercalated sequence of schistose and phyllitic, generally medium to dark greenishgray, fine-grained and massive metabasalt; dark-gray to black, generally fine-grained carbonaceous pelitic schist and phyllite and associated metasiltstone; and a few thin interbeds of black metachert, and fine- to medium-grained, dark-gray marble.

The metabasalts have been metamorphosed into mineral assemblages of chlorite, sericite, caicite, plagioclase--probably albite, opaque minerals, including leucoxene, and locally biotite. In some places original igneous minerals such as hornblende and plagioclase are still partly preserved (Wahrhaftig, 1968). In the north-central part of the quadrangle, agglomerate textures are moderately well preserved, and at one locality relict pillow structures were observed (Wahrhaftig, 1968).

The intercalated pelitic black schists and phyllites, as well as the associated metasiltstones, occur in interbeds several meters thick, and they essentially consist of quartz, sericite and (or) muscovite, and carbonaceous material.

Schistosity appears to parallel bedding. The metamorphic mineral assemblages suggest low-grade greenschist facies regional metamorphism (nomenclature after Turner, 1968). The age of the metamorphism, or even whether it is single or polymetamorphism, is uncertain. A potassium-argon age determination on metamorphic muscovite from one of the black phyllite interbeds (No. 8, table 1; Anderson, 1973; Sherwood and 
Craddock, 1979; Wilson and others, 1985b)

yielded a late Early Cretaceous age of 114.6 Ma.

The Late Devonian age of unit Dmb is rather well established by fossil evidence. One of the marble interbeds in the north-central part of the quadrangle yielded numerous conodont fragments of Palmatolepis sp. and Icriodus sp., some of which provisionally were identified to the species level, and specimens of Polygnathus sp. (No. 149, table 2; Sherwood and Craddock, 1979). This fauna indicates a Late Devonian age. In the northwest part of the quadrangle, two adjacent marble interbeds yielded conodont fragments, one identifiable as Polygnathus sp. (Nos. 151 and 152, table 2; Sherwood and Craddock, 1979), which ranges in age through the Devonian and Mississippian. Another marble interbed turned out to be barren of microfossils (No. 150, table 2).

Just as in the case of unit Dmf, the irregular outcrop patterns of unit Dmb, and its intercalation with other rock units, which appear to lie stratigraphically below or above it, strongly suggest that most, if not all, of its contacts with adjacent rock units are actually thrust faults (Warhaftig, 1968). Consequently, the structure and the tectonics of these rocks may be much more complex than what can be discerned in the field.

Not enough is known of the protoliths of unit Dmb to determine adequately their depositional environment. Unit Dmb definitely is a marine sequence and most probably was deposited along a continental slope and (or) in a deep basin.

According to Wahrhaftig (1968), unit Dmb probably is lithologically correlative with the Chute Creek Member of the Totatianika Schist (which is not divided into its formally named members in this report) near the north edge of the quadrangle.

Metasedimentary rocks (Late Devonian)-Unit occurs in discontinuous outcrops just north of the Hines Creek fault and appears to be closely associated with units Dmf and Dmb. The unit comprises an intercalated, generally thinly bedded, locally laminated, thick, marine sequence of dark-gray to black, carbonaceous, fine-grained pelitic schist or phyllite; dark-gray, fine-grained, carbonaceous metasiltstone (quartzose phyllite); fine-grained, medium-gray quartzite; thin interbeds of dark-gray to black metachert; and a few interbeds, as much as 5 $\mathrm{m}$ thick, of dark-gray, fine-grained fossiliferous marble in the outcrops of this unit near the west edge of the quadrangle (Gilbert and Redman, 1977). Metamorphic foliation is well developed and appears to parallel the bedding. Metamorphism has obliterated most of the primary sedimentary features, but the bedding in some of the metasiltstones appears to be graded.

The pelitic schists or phyllites and metasiltstones essentially consist of quartz, sericite and (or) muscovite, carbonaceous material, minor dolomite, and scattered idioblastic crystais of pyrite. The fine-grained quartzites have the same metamorphic mineralogy, except that quartz makes up more than 90 percent of the rock.

The metamorphic mineral assemblages suggest that the metamorphic grade of these rocks is within the low-pressure and lowtemperature field of the greenschist facies of Turner (1968). The age of metamorphism is unknown but it appears to be the same midCretaceous event as that of the surrounding metamorphic rocks.

Some of the marble interbeds near the west edge of the quadrangle yielded poorly preserved megafossils, still identifiable to the genus level, indicating a Late Devonian or perhaps Middle(?) Devonian age (Gilbert and Redman, 1977; Nos. 153-156, table 2).

As in the case of the already discussed units Dmf and Dmb, lithologic contacts between unit Dms and those of adjacent units may in fact be thrust faults, suggesting a complex structural and tectonic history. This is also suggested by some field observations and thinsection studies, as the primary foliation is commonly deformed by kink folding, slip cleavage, as well as large folds several meters in amplitude (Gilbert and Redman, 1977; this report).

The depositional environment for unit Dms appears to have ranged from shallow and (or) moderately deep marine, such as rocks with the marble interbeds in the westem part of the quadrangle, to deep marine along the Wood River. Most likely, this is the result of facies changes, but it is also possible that the rocks in the above two areas belong to two separate tectonic units, and thus are not correlative.

Unit Dms had been correlated tentatively with the pelitic and quartzose schists of unit Pzp€p (Wahrhaftig, 1968). However, the age of the marble interbeds near the west edge of the quadrangle, as well as the generally higher level of metamorphic recrystallization of the pelitic and quartzose schists of unit Pzpep make this correlation unlikely. Although there are rocks in the Totatlanika Schist that are very similar to unit $\mathrm{Dms}$, no obvious correlation seems to exist between any member of the Totatlanika Schist and unit Dms. On the other hand, the metasedimentary rocks of unit Dms that occur along the Wood River are very similar, if not 
identical, to the Yanert Fork sequence (unit Dy) in their lithologies, metamorphic grade and level of recrystallization, deformational style, and apparent age and depositional environment

Pzk Keevy Peak Formation (early Paleozoic)-The Keevy Peak Formation was first defined by Wahrhaftig (1968). It occurs along the northern flank of a regional antiform, in a stratigraphic position between the overlying Totatlanika Schist and the underlying pelitic and quartzose schists of unit Pzp€p. The formation comprises an intercalated sequence of fine- to medium-grained quartz-sericite or muscovite schist, fine-grained black quartzite, black carbonaceous pelitic schist and phyllite, stretched-pebble conglomerate, greenish-gray or purple schist and slate, and a few thin marble interbeds. The bulk of the formation appears to be composed of metamorphosed clastic rocks. According to Gilbert and Bundtzen (1979), many of the black quartzites are metacherts, and the varicolored slates are metatuffs. Many of the quartz-sericite or muscovite schists contain numerous porphyroblastic crystals, as much as $1 \mathrm{~mm}$ in maximum dimension, of bluish quartz and feldspar in the finer grained matrix, giving the rock a "grit-like" appearance (Wahrhaftig, 1968). Relict graded-bedding and crossbedding are locally preserved within the Keevy Peak Formation in spite of multiple deformation and metamorphism. Detailed lithologic descriptions of the Keevy Peak Formation can be found in Wahrhaftig (1968).

The Keevy Peak Formation underwent multiple deformation. The primary metamorphic foliation, which appears to parallel original bedding, is commonly transsected by kink-folding and axial-plane slip cleavage of tight or isoclinal folds as much as several tens of meters of amplitude. The occurrence of lenses of rocks characteristic of the Totatlanika Schist within the Keevy Peak Formation strongly suggests that these lenses are thrust slices (Wahrhaftig, 1968). Thus, lithologic contacts with the Totatlanika Schist are probably thrust faults, but the contact with the underlying pelitic and quartzose schists of unit $P_{z p} E_{p}$ is thought to be a depositional unconformity (Wahrhaftig, 1968).

Because of the structural complexities, the thickness of the Keevy Peak Formation is not known for certain, but over $700 \mathrm{~m}$ of section appears to be present.

In addition to the ubiquitous metamorphic minerals of quartz and sericite and (or) muscovite (present in various proportions depending on the composition of the protolith), most of the Keevy Peak contains carbonaceous material and subordinate amounts of metamorphic chlorite, calcite, feldspar, and rarely stilpnomelane. The metamorphic mineral assemblages indicate metamorphism of the greenschist facies (nomenclature after Turner, 1968). According to Gilbert and Bundtzen (1979), the Keevy Peak Formation underwent more than one period of regional metamorphism, the latest of which took place in the Cretaceous.

The age of the Keevy Peak Formation is imprecisely known. No fossils have been found so far in the Keevy Peak Formation or in rocks which might correlate with the Keevy Peak Formation. On the basis of regional geologic considerations, Wahrhaftig (1968) assigned the formation a Precambrian or Paleozoic age. In this report the Keevy Peak is considered to be early Paleozoic in age because it apparently rests depositionally on the underlying unit $P_{z p} \in p$, which, at least in part, is early Paleozoic in age.

The scarcity of original sedimentary features and lack of fossil data make it nearly impossible to speculate on the depositional environment of the Keevy Peak Formation. Gilbert and Bundtzen (1979) considered the formation to have been deposited in a relatively deep-marine, low-energy environment

Papep Pelitic and quartzose schist sequence (early Paleozoic and Precambrian?)-These rocks occur in a broad, east-trending belt, forming the core for a large regional antiform, in the northern part of the quadrangle. The metamorphic rocks of this unit, both within the Healy quadrangle and in adjacent regions, were previously mapped and designated by earlier workers as the now-abandoned Birch Creek Schist (for example, Brooks and Prindle, 1911; Capps, 1912, 1940; Péwé and others, 1966; Wahrhaftig, 1968, 1970b, 1970c, 1970d, 1970e; Gilbert, 1977; Gilbert and Bundtzen, 1976, 1979; Gilbert and Redman, 1977; Sherwood and Craddock, 1979). However, systematic reconnaissance geologic mapping in the type area of the Birch Creek Schist, in the Yukon-Tanana Upland, has revealed uncertainties as to what really constitutes the Birch Creek Schist as a rock stratigraphic unit (Foster and others, 1973). Foster and her coworkers have recommended that the term Birch Creek Schist be abandoned. On the recent geologic map of the Circle quadrangle (Foster and others, 1983), which includes the original type area of the Birch Creek Schist of Spurr (1898), the term Birch Creek Schist is not used. Accordingly, the term Birch Creek Schist is not used in this report.

The pelitic and quartzose schist sequence consists of the following rock types, 
intercalated in various proporations: mediumto fine-grained, generally medium-gray quartzsericite and (or) muscovite pelitic schist; fineto medium-grained, medium-gray quartzite; quartz-sericite and (or) muscovite-calcite pelitic schist; fine-grained, dark-gray to black carbonaceous schist or phyllite; a few interbeds, as much as several tens of meters thick, of medium-gray, fine- to mediumgrained massive marble: and a few small bodies and layers of chloritic schist, which originally probably were sills or interbedded flows or tuffs. The typical quartz-sericite and (or) muscovite pelitic schist, making up the bulk of the rocks of unit Pzp£p, has the following composition: $60-80$ percent quartz, 10-25 percent sericite and (or) muscovite, 510 percent calcite, $5-15$ percent albite and microcline, and frequently small amounts of chlorite, epidote, biotite, and carbonaceous material. More detailed lithologic descriptions of the rocks of unit $P_{2 p} E_{p}$ can be found in Wahrhaftig (1968), and in Gilbert and Redman (1977), under the term Birch Creek Schist.

Unit $P_{z p} \hat{C}_{p}$ appears to have undergone several periods of metamorphism and intense deformation (Wahrhaftig, 1968; Gilbert and Redman, 1977). Metarnorphic compositional layering defines a prominent foliation, which displays pervasive minor folding, and is cut by well-developed axial-plane slip cleavage. The metamorphic mineral assemblages suggest that unit $\mathrm{P}_{2 p} \in \mathrm{p}$, at least the bulk of it, belongs to the low-pressure and low-temperature field of the greenschist metamorphic facies of Turner (1968). The primary metamorphic foliation roughly parallels the contacts between unit $P_{z p} \mathcal{E}_{p}$ and other adjacent units of metamorphic rocks. The contact with the overlying Keevy Peak Formation $\left(P_{2} k\right)$ is thought to be a depositional unconformity, but all other contacts with metamorphic rock units are suspected to be thrust faults (Wahrhaftig, 1968). The base of unit Pzp€p is not exposed.

As the result of the structural complexities, and the fact that original depositional features, including bedding, have been obscured by metamorphism, the thickness of unit $P_{z p} €_{p}$ is not known. According to Wahrhaftig (1968), the thickness of this unit"... measured perpendicular to the axial plane cleavage of minor folds (not a true stratigraphic thickness) is at least 10,000 feet" (about $3,050 \mathrm{~m}$ ).

The age of the protoliths of unit Pzpep is imprecisely known. Only at one locality were indeterminate fossils found, suggesting an early Paleozoic age (Gilbert and Bundtzen, 1979; No. 171, table 2). No reliable age determinations by isotopic methods of any kind are so far available. Previously on the basis of regional geologic considerations, correlative rocks (under the name "Birch Creek Schist") in the adjacent Fairbanks quadrangle were assigned by Péwé and others (1966) to the Precambrian or early Paleozoic. The new fossil data by Gilbert and Bundtzen (1979) suggest that at least part of unit $P_{z p} E_{p}$ is Paleozoic in age. Because of the apparent great thickness of this unit, its base may be as old as Precambrian. Thus, in this report the age of unit Pzp€p is considered to be Precambrian(?) and early Paleozoic.

The lack of original depositional features as well as any determinate fossils preclude reliable speculations as to the depositional environment of the protoliths of unit Pzp£p. Wahrhaftig (1968) considered these rocks to be of sedimentary origin, probably as marine shales and sandstones, and Gilbert and Bundtzen (1979) interpreted the rocks of unit Pzp€p (under the name "Birch Creek Schist") to be continental-margin type deposits.

Unit $P_{z p} C_{p}$ is the oldest and (or) structurally lowest unit of the Yukon-Tanana terrane in the Healy quadrangle.

Not shown separately on the geologic map, there is a small exposure of sementinite within the rocks of unit $P_{2 p} \varepsilon_{p}$ just north of Montana Creek, in the north-central part of the quadrangle (Sherwood and Craddock, 1979). Its age is unknown, and it appears to have been derived from harzburgitic peridotite. The method and time of its emplacement are also unknown, but perhaps it is related to the thrusting assumed to separate most, if not all, of the rock units of the Yukon-Tanana terrane in the quadrangle

Rocks south of Hines Creek fault

Kcs Calcareous sedimentary rocks (Late Triassic; middle? Norian to late Karnian)-Unit occurs in a discontinuous, east-trending outcrop belt between the Hines Creek and McKinley fauits, and in discontinuous exposures south of the McKinley fault, in the eastem and central parts of the quadrangle. The unit comprises a generally thin bedded, commonly crossbedded, carbonaceous, darkto medium-gray, marine, intensely deformed thick sequence of intercalated calcareous shale, argillite, sandstone, siltstone, and sandy to silty and argillaceous limestone. The sequence is interpreted to be continental-slope type turbidite and capping-shelf type deposits. Not shown separately on the geologic map, the sequence also contains numerous large dikes, sills as much as several tens of meters thick, and small plugs of altered diabase and gabbro. In the eastern and southem parts of the quadrangle, the rocks of the sequence 
have been regionally metamorphosed into greenschist and amphibolite facies assemblages (Csejtey and others, 1982, 1984). The metamorphosed rocks are part of a northeast-trending, apparently late-tectonic, in situ metamorphic belt, the Maclaren metamorphic belt of Smith (1974), of midCretaceous age (Nos. 34, 37, and 39, table 1; map $C$, sheet 2 of this report).

As indicated in a well-exposed ridge-top outcrop just south of the Wood River, the Triassic calcareous sedimentary rocks ( $k \mathrm{cs}$ ) rest with a slight angular unconformity on unit Dy, which is herein correlated with rock sequences of the Yukon-Tanana terrane north of the Hines Creek fault (to be discussed subsequently). The top of the Triassic calcareous sedimentary rocks sequence is nowhere exposed.

Unit Kas is intensely and penetratively deformed and as mentioned earlier, locally metamorphosed. Isoclinal folding, high-angle reverse and normal faults are common. At several localities the Triassic calcareous sedimentary rocks and underlying unit Dy have been imbricated by thrust faults of unknown horizontal displacement. The deformation is the result of at least two periods of deformation, which affected south-central Alaska: a very severe orogenic deformation in about mid-Cretaceous time and a comparatively minor one in the Cenozoic (Csejtey and others, 1982). As a result of the intense deformation, the maximum preserved thickness of the Triassic calcareous sedimentary rocks sequence is uncertain but it is estimated to be greater than $1,000 \mathrm{~m}$.

The age range of the Triassic calcareous sedimentary rocks (unit $\mathrm{kcs}$ ) is from late Karnian to middle(?) Norian time during the Late Triassic. These ages are based mainly on the occurrences of the conodont species Neogondolella polygnathiformis and Epigondolella primitia, found in samples collected by the U.S. Geological Survey (this report) as well as in samples collected by workers from the University of Wisconsin (Sherwood and Craddock, 1979; Umhoefer, 1984; see also Nos. 72-75, 82-84, and 8796A, table 2). The same Late Triassic conodont faunas occur in samples both from north and south of the McKinley fault of the Denaii fault system and in both areas from rocks of similar depositional environments. The conodont faunas from the Healy quadrangle are the same as the faunas reported by Jones and others (1981b) from correlative strata to the southwest. Only one megafossil locality was discovered in the Healy quadrangle (No. 93, table 2), and it contained fragments of the pelecypod Monotis cf. M. subcircularis (N.J. Silberling, written commun., 1982), the age of which correlates with the age range of the conodonts. At several localities, the Triassic calcareous rocks also yielded trace fossils, namely Chondrites sp. (Nos. 76-81, 85, and 86, table 2).

The Triassic calcareous sedimentary rocks ( $\mathrm{kCs}$ ) are interpreted to represent a marine regressive sequence, with deep continentalslope type deposits at the base, overlain by progressively shallower slope deposits, then by outer shelf, and finally by inner shelf deposits. The slope deposits make up the majority of the sequence, whereas the shelf-type deposits constitute only about the uppermost one-fifth of the known sections. The regressive episode may have been caused by a relative sea-level change coupled with a large sediment supply, which allowed the progradation of shallow. water sediments over outer-shelf and slope deposits. The deeper continental-slope deposits consist of turbidites and intercalated hemipelagic sediments, both of which are commonly bioturbated. The turbidites are thin-bedded, generally base-cut-out turbidites, which progress upward from cross-laminated, fine-grained calcareous sandstone and siltstone to parallel-laminated calcareous siltstone, and finally to carbonaceous shale and argillaceous limestone (Tc-Te layers of Bouma, 1962, 1964). In places complete Bouma Ta-Te turbidites are also present, but they are thin (as thick as $25 \mathrm{~cm}$ ) with parallelbedded (Tb) and normal graded basal sandstone ( $\mathrm{Ta}$ ) layers. Channel conglomerates were not found. The hemipelagic rocks comprise intercalated argillaceous limemudstone, carbonaceous shale, and calcareous siltstone with a few, thin turbidite interbeds (usually Bouma Tc-Te layers). At several localities, the slope-type deposits also contain intercalations, as thick as a few meters, of nonbioturbated, alternatingly light- and dark-colored laminae of carbonaceous and argillaceous lime-mudstone (nomenclature after Dunham, 1962). These lime-mudstone intercalations probably were deposited either in an interslope oxygen-starved basin, or within the oxygen-minimum zone of an open slope, where infaunal invertebrates are uncommon. The upper-slope and outer-shelf deposits are represented by medium- to thickbedded, calcareous, fine- to medium-grained sandstones, siltstones, and shales, generally without small-scale sedimentary structures, such as parallel-laminations and crossbedding. These were probably destroyed by bioturbation (some trace fossils are present). The inner-shelf deposits are fine- to coarsegrained, calcareous sandstones; and quartzgrain, skeletal packstones and grainstones 
(nomenclature after Dunham, 1962) with medium- to small-scale planar crossbedding. The carbonate grains consist of fragments of molluscs, brachiopods, echinoderms, and encrusting foraminifers, as well as peloids and limestone clasts. Many of the quartz and carbonate grains have relict coats of rim cement, indicating vadoze-zone cementation prior to neomorphism. These deposits probably were produced by a series of migrating barrier bars in a wave-dominated environment.

The diabase and gabbro intrusive rocks are generally massive, medium to dark greenish gray, fine to coarse grained, and strongly altered. Locally, the gabbros are pegmatitic. These intrusive rocks underwent the same degree of deformation, and locally metamorphism, as the sedimentary country rocks. In addition to occurring within unit $\mathrm{k} c \mathrm{c}$, both north and south of the McKinley fault, these mafic intrusive rocks are also present within unit Dy unconformably underlying the Triassic calcareous rocks. Numerous attempts to date these intrusive rocks by the potassium-argon method have proved to be unsuccessful so far (Sherwood and Craddock, 1979). The diabases and gabbros intrude rocks as young as Norian in age and in turn are intruded by mid-Cretaceous granitic rocks (Kgr). Most probably they are Jurassic or Early Cretaceous in age.

As already discussed, the Triassic calcareous sedimentary rocks occur both north and south of the McKinley fault of the Denali fault system. In the past, the rocks north of the McKinley fault have been assigned to the socalled Pingston terrane, whereas the rocks south of the fault to the so-called Nenana tectonostratigraphic terrane (for instance, Jones and others, 1981a). In this report, on the basis of the overwhelming lithologic and stratigraphic similarities between the two suites of rocks, and their identical conodont faunas and age spans, the Triassic calcareous sedimentary rocks north and south of the McKinley fault are considered to be tectonically telescoped parts of the same sequence of continental-slope and shelf-type deposits and most probably to be part of the Yukon-Tanana terrane

Yanert Fork sequence (Late Devonian)-Informal name used in this report for an intensely deformed, thick marine sequence of dominantly metasedimentary and metavolcanic rocks cropping out primarily in the headwater region of Yanert Fork, in the eastem part of the quadrangle. The bulk of the sequence comprises dark-gray to black carbonaceous shale with intercalations of thinbedded, commonly bioturbated, medium- to dark-gray, normally graded, both cross- and parallel-laminated, fine- to medium-grained lithic sandstone, and siltstone (turbidites). Most of these rocks have been regionally metamorphosed into siliceous mudstone, argillite, slate, phyllite, semischist, and impure quartzite. The sequence also contains thin interbeds of dark- to medium-gray, locally greenish-gray, banded chert or metachert, commonly with radiolarians; several-metersthick interbeds of pale greenish-gray and medium-gray, very fine grained siliceous phyllite, most probably felsic metatuff; a few several-meters-thick interbeds of dark brownish-or greenish-gray phyllitic metabasalt, locally with still recognizable pillow structures and vesicles; subordinate stretched-pebble schistose conglomerate interbeds a few meters thick; and a very few, thin interbeds, as much as $30 \mathrm{~cm}$ thick, of medium-gray, fine- to medium-grained impure marble. The Yanert Fork sequence also contains the same, probably Jurassic or Early Cretaceous diabase and gabbro intrusions, locally making up more than half of the exposed sections, as in the Triassic calcareous sedimentary rocks unit ( $\mathrm{kcs}$ )

The Yanert Fork sequence is overlain with a slight angular unconformity by the Triassic calcareous sedimentary rocks unit ( $\mathrm{k} \mathrm{cs}$ ), but the base of the sequence is nowhere exposed. Because of the intense deformation, including isoclinal folding and repetitions of section by several, laterally untraceable thrust faults of unknown horizontal displacements, the thickness of the Yanert Fork rocks is not known, but the maximum preserved thickness is estimated to be in excess of $1,000 \mathrm{~m}$.

The metamorphic grade of the Yanert Fork rocks is generally low. Field observations, and thin-section and $\mathrm{x}$-ray diffraction studies for a number of samples indicate that the bulk of the Yanert Fork rocks is in the lowtemperature and low-pressure field of the greenschist metamorphic facies (definition of metamorphic facies after Turner, 1968). Only along the east edge of the quadrangle have the Yanert Fork rocks been metamorphosed into mineral assemblages of the low-grade amphibolite facies (Csejtey and others, 1982; and this report). The age of metamorphism probably is mid-Cretaceous (No. 14, table 1). No evidence of regional polymetamorphism was detected but the evidence for it might not be apparent because of the fine grain-size and generally low metamorphic grade of the rocks.

The age span of the rather thick Yanert Fork sequence is imperfectly known. A marble interbed just west of Louis Creek yielded several specimens of the conodont fossil Palmatolepis sp. of Late Devonian age 
(Frasnian-Famennian; No. 157, table 2). No other identifiable fossils were found in the Yanert Fork rocks. Chert samples from a number of localities were examined for radiolarians, but none could be identified due to the effects of metamorphism (N.R.D. Albert, U.S. Geological Survey, written and oral commun., 1982; C.D. Blome, U.S. Geological Survey, written commun., 1982; Nos. 158164, table 2). Thus, on the basis of the conodont evidence, the Yanert Fork sequence is herein considered to be of Late Devonian age. However, because of the thickness of the Yanert Fork sequence, it is possible that rocks of other than Late Devonian age are also present.

The lithologies of the Yanert Fork sequence indicate that its rock components are a mixture of continentally derived and pelagic sediments (for example, the turbidites and the conglomerates versus the banded radiolarian cherts). Thus, the sequence is interpreted to be continental margin type sediments, which were deposited along the base of a continental slope.

The lithologies, the depositional environment, the general metamorphic grade, the known age, and the structural style of intense, penetrative deformation, especially that of imbricate thrusting, of the Yanert Fork sequence are identical, or at least very similar, to those of several of the Paleozoic units of the Yukon-Tanana terrane north of the Hines Creek fault. Thus, in this report, the Yanert Fork sequence is considered to be part of the Yukon-Tanana terrane. Accordingly, the overlying Triassic calcareous sedimentary rocks unit (KCs) is also considered part of the Yukon-Tanana terrane. If the correlation is valid, then neither the Hines Creek fault nor the McKinley fault are major tectonostratigraphic terrane boundary faults, as the Yukon-Tanana terrane extends to the south of both of these faults

\section{Flysch and associated rocks}

Andesitic subvolcanic rocks (Late Cretaceous) -This unit consists of two large sills or dikes intruding the metamorphosed flyschlike rocks of unit KJf, in the southeastern part of the quadrangle. The rock constitufing the sills is an altered, medium-greenish-gray, porphyritic homblende andesite, containing subhedral to euhedral phenocrysts, as much as $5 \mathrm{~mm}$ in maximum dimension, of prismatic hornblende and altered plagioclase in an aphanitic matrix. The matrix, originally microcrystalline or very finely crystalline, now consists of a very fine grained aggregate of sericite, chlorite, clay minerals, opaques, very minor quartz, and some relict plagioclase. The hornblende phenocrysts are still quite fresh, but the plagioclase phenocrysts have been altered to sericite, clay minerals, and some quartz. A potassium-argon age determination on hornblende yielded an early Late Cretaceous age of $97.3 \mathrm{Ma}$ (No. 43, table 1). The intrusion of the two andesite sills appears to postdate the greenschist facies regional metamorphism of the flyschlike country rocks of unit KJf

KJf Flysch sequence (Early Cretaceous and Late Jurassic)-The rocks included in this unit comprise a monotonous, intensely deformed and locally highly metamorphosed, probably several thousands of meters thick, flyschlike turbidite sequence, which underlies large areas in the western, central, eastern, and southern parts of the quadrangle. The sequence consists of a variety of rock types, intercalated in varying proportions. These are: dark-gray to black argillite; fine- to coarse-grained, generally dark-gray lithic graywacke; dark-gray polymict pebble conglomerate; subordinate black chert-pebble conglomerate; a few thin interbeds of dark-gray to black radiolarian chert; and a few thin beds of dark-gray. impure limestone.

In the southeastem part of the quadrangle, the flysch sequence has been intensely metamorphosed, and is part of an in situ, northeast-trending metamorphic belt, first described and named by Smith $(1970,1974)$ the Maclaren metamorphic belt, of about midCretaceous age. The axis of the belt in the quadrangle runs from about Deadman Mountain northeasterly toward an area south of Butte Lake, then toward Rusty Hill and on through the area of the Susitna Glacier (Csejtey and others, 1982, 1984; map C, sheet 2 of this report). Along the core of the metamorphic belt the metamorphic grade is that of the amphibolite facies (nomenclature after Turner, 1968), which rapidly decreases toward both flanks to the greenschist, and to the prehnite-pumpellyite metamorphic facies. Within the beit the metamorphosed flyschlike rocks consist of fine- to medium-grained paragneisses, fine- to medium-grained pelitic schists, and phyllites.

The whole flysch sequence has been compressed into tight or isoclinal folds and has been complexly faulted, including thrust faults. Even outside the Maclaren metamorphic belt, the flyschlike rocks are highly indurated, and many are sheared and pervasively cleaved. Most of this cleavage is probably axial-plane cleavage. Because of the lithologically monotonous nature of the flysch sequence, thrust faults are especially hard to detect in the field. The notable exception is a large klippe or thrust sliver in the south-central and 
southwestern parts of the quadrangle. There, in a formerly very large thrust sheet, rocks of the flysch sequence were thrust upon the same flysch sequence and on the Upper Triassic rocks of unit Kvs and then were compressed into a tight, giant megafold with a calculated amplitude of at least $10 \mathrm{~km}$ (Csejtey and others, 1982; cross section $A-A^{\prime}$ of this report). The present surface dimensions of the klippe are about 30 by $60 \mathrm{~km}$. In order to show the areal extent of this klippe on the geologic map, the flyschlike rocks of the klippe are mapped as unit KJfk. However, lithologically they are identical to the flyschlike rocks of unit KJf.

The typical argillite of the flysch sequence is dark-gray to black, and it commonly contains small grains of detrital mica as much as $1 \mathrm{~mm}$ in diameter. Because of the intense deformation and accompanying dynamomentamorphism, in large areas the argillite is actually a slate or fine-grained phyllite. Thin-section examination indicates that some of the argillites are very fine grained siltstones, and that they all contain considerable carbonaceous material.

The typical lithic graywacke is dark- to medium-gray, fine- to medium-grained, and occurs intercalated with the argillite in graded beds ranging in thickness from laminae to about $1.5 \mathrm{~m}$. The individual graywacke beds are not uniformly distributed throughout the whole sequence, of which they comprise about 30 to 40 percent by volume, but tend to be clustered in zones 1 to $5 \mathrm{~m}$ thick. Examination of thin sections of graywacke samples indicate a composition of angular or subrounded detrital grains of lithic fragments, quartz, moderately tresh plagioclase, and some generally altered mica in a very fine grained matrix. Euhedral opaque grains, probably authigenic pyrite, are present in most thin sections. The lithic fragments consist, in various proportions, of little-altered, finegrained to aphanitic volcanic rocks of mafic to intermediate composition; fine-grained, weakly foliated low-grade metamorphic rocks; chert; and some fine-grained unmetamorphosed sedimentary rocks possibly of intraformational origin. No carbonate grains were seen. The matrix constitutes about 20 to 30 percent of the rock by volume, generally contains some secondary sericite and chlorite, and, in some of the more dynamometamorphosed rocks, biotite.

The polymict pebble conglomerate is generally dark to medium gray, well indurated, with poorly to well-sorted layers as much as several meters thick. Clasts are well rounded to subrounded, and range in size from about $2 \mathrm{~mm}$ to about $15 \mathrm{~cm}$, but most clasts are less than $5 \mathrm{~cm}$ in diameter. In various proportions, the clasts consist of black and dark-gray chert; dark- to medium-gray argillite and sandstone or graywacke, some of which may be of intraformational origin; gray quartzite; and subordinate amounts of pebbly sandstone and conglomerate, white quartz, and gray-green chert. Some of the sandstone or graywacke clasts may actually be altered volcanic rocks.

Within the Maclaren metamorphic belt, the flysch sequence have been recrystallized, depending on the metamorphic grade, into compositionally layered gneisses and schists, primarily consisting of quartz, muscovite, biotite, and feldspar, and into phyllites of quartz, sericite, and (or) muscovite. The highest grade of metarnorphism occurs in the area around Rusty Hill, where the metamorphic mineral assemblages include kyanite, staurolite, and sillimanite, indicating an intermediate-pressure field of the amphibolite metamorphic facies. A thorough discussion of the metamorphic rocks and the developmental history of the Barrovian-type Maclaren metamorphic belt in the Healy A-1 quadrangle is given by Smith (1981).

The age of the Maclaren belt metamorphism, at least its main phase, is about mid-Cretaceous, but it is possible that the age of this apparently complex metamorphic episode may range from Late Jurassic to early Tertiary. Several potassium-argon age determinations on mineral separates from these metamorphic rocks of unit KJf (Nos. $43-45$, and 48 , table 1) yielded latest Late Cretaceous and early Tertiary ages. However, these ages are herein considered to be minimum reset ages because potassium-argon age determinations on metamorphosed rocks of unit kcs to the north (Nos. 34 and 37, table 1), produced by the same metamorphism, yielded somewhat older Late Cretaceous ages. But these ages may also be reset ages because still older granitic rocks (Kgr) seem to intrude the already metamorphosed rocks.

The depositional age span of the flysch sequence is fairly well established by fossil evidence, both from within and outside the quadrangle (for example, Reed and Nelson, 1980: Csejtey and others, 1978; Jones and Silberling, 1979), although fossils are very sparse in the sequence. A number of localities within the quadrangle yielded microfossils and (or) megafossils, which range in age from Late Jurassic to Early Cretaceous (Nos. 24-26, and $39-42$, table 2). Included in this fossil list are the fossils from unit KJfk in the south-central part of the quadrangle. Unit $\mathrm{KJfk}$ is considered to be part of the flysch sequence, and it is designated separately on the geologic 
map only to show the extent of a large klippe formed by rocks of the flysch sequence. The rocks mapped as unit $\mathrm{KJfl}$ are also considered to be part of the flysch sequence because of identical lithologies, but in addition to Late Jurassic and Early Cretaceous fossils, these rocks also yielded fossils of earliest Late Cretaceous (Cenomanian) age, thus they are shown separately on the geologic map. It is quite likely that the deposition of all of the flyschlike rocks, including unit KJf, extended into the earliest Late Cretaceous, but as a result of subsequent deformation and erosion, only in a few areas are rocks of this young age preserved.

The flyschlike rocks of the quadrangle are part of a thick, dominantly turbidite sequence, which underies large areas of southern Alaska. The flysch sequence is interpreted to have been deposited more or less in situ, in a narrowing oceanic basin between, and lapping onto, the late Mesozoic North American Continent, which the Yukon-Tanana tenane was already a part of, and the converging Talkeetna superterrane (Csejtey and others, 1982). Thus, the flyschlike rocks of the quadrangle, as well as those of southern Alaska, are the intensely deformed remnants of turbidite deposits of a once large but narrowing and subsequently collapsed oceanic basin between converging continents

KJfk Overthrust flyschlike rocks-These rocks are identical lithologically and in age (Late Jurassic and Early Cretaceous) to the flyschlike rocks of unit KJf. They are designated separately on the geologic map only to show the extent of a large, folded klippe or thrust sliver, about 30 by $60 \mathrm{~km}$ in maximum areal dimensions, in the southwestern and south-central parts of the quadrangle (see cross section $A \cdot A^{\prime}$ ). The klippe is the remnant of a once much larger thrust sheet that imbricated the flysch sequence and also brought the flyschlike rocks on top of Triassic basalts and volcaniclastic rocks of unit kvs. Three localities within the klippe yielded megafossils and microfossils of Jurassic and Early Cretaceous ages (Nos. 24 26, table 2)

$\mathrm{KJ} c \mathrm{C}$ Conglomerate, sandstone, siltstone, shale, and volcanic rocks (Early Cretaceous and Late Jurassic)-These rocks occur in two thrust slivers along the Talkeetna thrust fault in the southeastern part of the quadrangle. They comprise an intercalated sequence of polymictic pebble and cobble conglomerate, sandstone, siltstone, shale, and flows and dikes of andesitic to latitic feldspar porphyry. Some of these rocks appear to have undergone very low grade regional metamorphism. Locally, the rocks are strongly sheared with shear planes cutting across conglomerate clasts. The best exposed section, south of Butte Creek, is over $400 \mathrm{~m}$ thick, and it contains many fining- and thinning-upward sequences (sequences in which the clastic component grain size and thickness of individual beds decrease stratigraphically upward).

The conglomerates are massive to thick bedded with common nonstratified grading and clast imbrication (organized conglomerate). The well-rounded to subrounded clasts range from about 1 to $20 \mathrm{~cm}$ in maximum dimension, and chiefly consist of unmetamorphosed andesite, latite, dacite, feldspar porphyry, and altered basalt and diabase, which resemble the nearby Nikolai Greenstone ( $\mathrm{k} n$ ). Sedimentary rock types comprise about 40 to 45 percent of the clasts and consist of greenish-gray tuffaceous sandstone and siltstone: dark- to mediumgray, fine- to medium-grained sandstone; dark-gray siltstone; dark-gray argillite; and some white quartz. The clasts generally are grain supported with small amounts of polymictic sandy matrix, which is locally altered to a clay-mica-quartz or a sericitequartz-prehnite aggregate.

The sandstone, siltstone, and shale are thinly to moderately thickly bedded and form intercalated sequences of graded and crossbedded sandstone and siltstone and parallel-laminated siltstone and shale (turbidites). These rocks generally are medium to dark gray with common feldspar grains, but dark greenish-gray varities are also present that contain abundant tuffaceous material.

The dark-gray andesitic to latitic feldspar porphyry, occurring as dikes and flows, contains flow-aligned phenocrysts of zoned andesine and oligoclase as long as $1 \mathrm{~cm}$, along with various amounts of homblende and biotite, in an aphanitic matrix.

The age of this unit is based on the occurrence of specimens of Buchia spp. of Late Jurassic to Early Cretaceous age (Silberling and others, 1981a; No. 27, table 2) in a shale bed at the top of the 5,053-ft peak near the south edge of the quadrangle.

Unit $\mathrm{KJ} c \mathrm{~g}$ was probably deposited at the base of a continental slope as part of a submarine fan complex. The organized conglomerates are the channel facies of the complex and are equivalent to facies $A_{2} 2$ of Walker and Mutti (1973). The fining- and thinning-upward sequences in the section south of Butte Creek grade from channelfacies conglomerate to interchannel-facies siltstone and shaie. These repeated sequences probably were formed by channel migration across this fan complex.

The lithologies and age range of unit $\mathrm{KJ} c \mathrm{cg}$ 
provisionally suggest that they might constitute a submarine fan facies of the Upper Jurassic and Lower Cretaceous flysch sequence (KJf) of the quadrangle, or that they may correlate with, and thus be the westernmost, occurrence of the Gravina-Nutzotin sequence of Berg and others (1972) in eastern Alaska

\section{Talkeetna superterrane}

Kvs

Metavolcanic, metavolcaniclastic, and subordinate metasedimentary rocks (Late Triassic; late Norian)-Unit consists of intercalated sequences several hundreds of meters thick and occurs as thrust slices in the southeastern and southwestern regions of the quadrangle. Two of these slices occur along the Talkeetna thrust fault, and the others, including the largest one, are sandwiched between the East Fork and Honolulu thrusts near the southwest comer of the quadrangle. Although there are some variations in the rock types and in the proportions of rock types between the discontinuous slivers, the overall lithologic similarities and the same fossils, hence the same age of these rocks, make correlation reasonably certain. Previously, the rocks in the various slivers have been assigned to different tectonostratigraphic terranes, namely the Susitna, Wrangellia, and Clearwater terranes (Jones and others, 1981a; Silberling and others, 1981a, 1981b).

The most common rock type in these slivers is a dark greenish-gray aphanitic metabasait containing numerous amygdules. Most of the metabasalts occur in thick, commonly pillowed, massive flows. Examination of thin sections indicate the primary minerals to be twinned labradorite, augite, and opaque minerals, which probably are mostly ilmenite. Secondary minerals are chlorite (much of it after glass), epidote, clinozoisite, minor zoisite, calcite, leucoxene, very minor sericite, very fine grained felty amphibole (probably seralite after augite), and possibly very subordinate albite. The original texture was intersertal and subop.itic. The amygdules consist of chlorite, zeolites (primarily prehnite), quartz, and some feldspar. Some of the metabasalts are pyroclastic in origin, forming thick layers of agglomerate comprising chaotic assemblages of coarse, angular to subangular basalt fragments with subordinate exotic rock fragments such as argillite or marble; all the fragments are densely packed in a finegrained, greenish-gray or reddish-gray matrix.

The metavolcaniclastic rocks comprise darkgray or dark greenish-gray, generally fine grained, tuffaceous metasandstones and metasiltstones, occurring either as severalmeters-thick interbeds within the metabasalts, or forming thick, monotonous sections a few hundreds of meters thick.

The metasedimentary rocks comprise darkgray, locally greenish-gray slate and argillite, and subordinate dark-gray, finely crystalline, thinly bedded marble. Examination of thin sections of the slates indicate that some of them are fine-grained metasiltstones. All of the slates and argillites contain considerable carbonaceous material and some amounts of fine-grained, secondary sericite. Secondary bioitite is present in some of the slates. The subordinate, thinly bedded marbles occur in uncommon layers several meters thick.

The secondary mineral assemblage in rocks of unit Kvs suggest that, in addition to the deuteric alteration of the volcanic rocks, all of the unit underwent very low grade regional metarnorphism, which locally may reach the low-pressure and low-temperature field of the greenschist metamorphic facies (nomenclature after Turner, 1968).

At several localities the slates, argillites, metasandstones, and marbles yielded the megafossils Monotis subcircularis and (or) Heterastridium sp. of late Norian (Late Triassic) age (Nos. 97-99, 101, and 102, table 2).

At a locality in the Talkeetna Mountains D2 quadrangle, about a mile south of the south boundary of the Healy quadrangle, limestone fragments from an agglomerate layer of unit Kvs yielded conodont species of Late Triassic (late Karnian to early Norian) age (No. 100, table 2). This age is equivalent to that of the Chitistone and Nizina Limestones of the Wrangellia terrane (Jones and others, 1977), a component of the Talkeetna superterrane (Csejtey and others, 1982). These limestone fragments, as thick as $12 \mathrm{~cm}$ in maximum diameter, lithologically resemble the undivided Chitistone and Nizina Limestones ( $\mathrm{k} \mathrm{Cn}$ ) found elsewhere in the quadrangle. If these limestone fragments indeed come from unit $\mathrm{k} \mathrm{cn}$, that is, from the Wrangellia terrane, then this would indicate that basalts do occur in the stratigraphic section of the Wrangellia terrane above the undivided Chitistone and Nizina Limestones. No basalts have been recognized previously in this stratigraphic interval of the Wrangellia terrane (for instance, Jones and others, 1977, 1981a; Jones and Silberling, 1979).

Unit Kvs represents a series of submarine volcanic flows and pyroclastic deposits, as well as interfingering volcaniclastic and pelagic (open-ocean) sediments, which were deposited contemporaneously with and between eruptive events

Chitistone and Nizina Limestones, undivided (Late Triassic; early Norian and late Karnian)-This unit occurs in three separate, 
small thrust slivers in the southeastern part of the quadrangle. The unit comprises several varieties of limestones, the compositions of which are various between the slivers. These lithologic variations apparently are the result of facies changes and subsequent telescoping by thrust faults. The ages and lithologies of these limestones are very similar to the typeChitistone Limestone of eastern Alaska but parts of these limestones also correlate with the type-Nizina Limestone, stratigraphically overlying the Chitistone, of the same area (MacKevett, 1976, 1978). On the basis of this correlation, unit $\mathrm{k} \mathrm{cn}$ comprises the youngest strata in the Healy quadrangle, which are certain to be part of the Wrangellia (tectonostratigraphic) terrane of Jones and others (1977).

The thrust sliver near Butte Creek (No. 104, table 2) is composed of a medium- to thickbedded, medium-gray weathering, brownishgray lime mudstone (nomenclature after Dunharn, 1962) with chert nodules and streamers. The sliver to the south (No. 103, table 2) consists of a medium- to thin-bedded, commonly thinly laminated, dark-gray to dark brownish-gray lime mudstone that releases a fetid (possibly petroleum) odor when broken. The sliver in the Clearwater Mountains (No. 105, table 2), near the east edge of the quadrangle, is made up of thin- to mediumbedded, dark-gray lime mudstone and wackestone (Silberling and others, 1981a, 1981b). All of the above exposures show evidence for at least incipient recrystallization, possibly as the result of very low grade regional metamorphism.

Two of the fault slivers are fossiliferous and yielded the megafossil Halobia sp., as well as several conodont specimens (Nos. 103 and 105 , table 2), all of which indicate a late Karnian and early Norian (Late Triassic) age range.

Because all the exposures of the undivided Chitistone and Nizina Limestones in the quadrangle are fault bounded, their stratigraphic thicknesses and positions are somewhat conjectural. At least several tens of meters of section are present. On the basis of correlation with the Chitistone Limestone in the Nabesna and McCarthy quadrangles of eastern Alaska (Richter, 1976; MacKevett, 1976,1978 ), it is fairly certain that in the Healy quadrangle the undivided Chitistone and Nizina Limestones stratigraphically overlay the Nikolai Greenstone ( $k n$ ) prior to thrusting.

On the basis of similar lithologies and fossil contents, and thus age range, unit $\mathrm{k} \mathrm{cn}$ in the Healy quadrangle correlates well with the Chitistone Limestone and the lower part of the Nizina Limestone at their type sections in the
McCarthy quadrangle (MacKevett, 1976, 1978).

The depositional environment of the cherty limestone in the sliver near Butte Creek (No. 104 , table 2) is interpreted to be supratidal. This is suggested by the irregular form of the chert nodules, characteristic of postdepositional origin and by the lack of fossils. The limestone in the sliver to the south (No. 103 , table 2) probably was deposited in deeper water, possibly at bathyal water depths (more than $200 \mathrm{~m}$ ). This is suggested by the fine grain size, thin laminations, common pelagic megafossils, and the small, delicate conodont fauna. The lime mudstone and bioclastic wackestone in the sliver near the east edge of the quadrangle (No. 105, table 2) probably was deposited in a subtidal innershelf or shallow-platform environment

Fn Nikolai Greenstone (Late and (or) Middle Triassic-The formation occurs near the southeast corner of the quadrangle, south of the Talkeetna thrust fault. The Nikolai is one of the most prominent and widespread rock units of the Wrangellia (tectonostratigraphic) terrane in southern and eastem Alaska. In the Healy quadrangle, the Nikolai Greenstone comprises an over 3,000-m-thick, slightly metamorphosed sequence of massive basalt flows with subordinate amounts of intercalated basaltic tufts and breccias, some bedded volcaniclastic rocks such as pebble conglomerate, sandstone, and siltstone, and possibly a few thin limestone interbeds. The entire sequence has been telescoped and offset by numerous faults.

The Nikolai Greenstone can be roughly subdivided into two parts in the quadrangle (Silberling and others, 1981a, 1981b). The upper part is an over 1,000-m-thick pile of dominantly subaerial, massive flows of dark greenish-gray, arnygdaloidal basalt. The individual basalt flows are as much as a few tens of meters thick. These amygdaloidal basalts closely resemble the type section of the Nikolai Greenstone in the Wrangell Mountains (MacKevett, 1976, 1978). The lower part of the Nikolai is over $2,000 \mathrm{~m}$ thick, and it comprises a number of laterally variable and interfingering rock types, probably all of submarine origin. These rock types are: massive flows of dark greenish-gray, nonamygdaloidal basait; massive flows of light to medium greenish-gray pillow basalt interlayered with tuff; and massive, layered breccia of dark greenish-gray basalt clasts. The clasts range from subangular to rounded, and are as much as $20 \mathrm{~cm}$ in maximum dimension. According to Silberling and others (1981a), this lower part of the Nikolai may be equivalent to the Paxson Mountain Basalt of 
Stout (1976). At several localities within the quadrangle, the Nikolai Greenstone is cut by diabasic and gabbroic dikes, which are interpreted to be feeder dikes for the basalt flows higher up in the section. For more detailed lithologic descriptions of the Nikolai and for the distribution of its various rock types in the Healy A-1 quadrangle, the reader is referred to Silberling and others (1981a, 1981b) and to Smith (1981).

The Nikolai Greenstone in the quadrangle underwent an apparently single event of lowgrade regional metamorphism. Secondary mineral assemblages in the basalts (Silberling and others, 1981b; Smith, 1981) suggest the metamorphic grade to be that of the prehnitepumpellyite metamorphic facies (nomenclature after Turner, 1968). The age of this metamorphism is not known for certain, but in this report the metamorphism is considered to be part of the approximately mid-Cretaceous regional metamorphic event affecting large parts of the Healy quadrangle.

The age of the Nikolai Greenstone has been determined in the Wrangell Mountains of eastern Alaska by the ages of the bracketing sedimentary rocks, as no fossils had been found in this largely subaerial formation (MacKevett, 1976, 1978; Jones and others, 1977). In the Wrangells, the Nikolai is underlain by the socalled "Daonella beds" of middle Ladinian (Middle Triassic) age and is overlain by upper Karnian (Upper Triassic) beds of the Chitistone Limestone. Thus, the Nikolai has been designated to be Middle and (or) Late Triassic in overall age. In the Healy A-1 quadrangle, a poorly exposed limestone bed within the Nikolai Greenstone yielded the fossil Halobia superba of late Karnian to early Norian age (No. 106, table 2). Unfortunately, it could not be determined for certain in the field that this limestone is an interbedded lens in the youngest part of the Nikolai. So far, such a young age for the upper part of the Nikolai has not been demonstrated in Alaska. However, thin interbeds of limestone within the Nikolai in the Healy A-1 quadrangle have been reported by Seraphim (1975). On the other hand, it is also possible that these limestones are thrust slivers of the undivided Chitistone and Nizina Limestones (unit $\mathrm{k}(\mathrm{Cn}$ ) within the Nikolai Greenstone.

In the Healy quadrangle and adjacent areas, the dominantly marine character of the Nikolai Greenstone makes it markedly different from the largely subaerial Nikolai at its type area in the Wrangell Mountains (MacKevett, 1976, 1978). The Nikolai in the Healy quadrangle and adjacent areas appears to indicate and to be part of a large-scale lateral facies change from a nonmarine to a marine environment in the Alaskan parts of the Wrangellia terrane during Nikolai time.

Paleomagnetic studies on the Nikolal Greenstone in various parts of Alaska (Hillhouse, 1977; Stone, 1982), including the Healy quadrangle (Hillhouse and Grommé, 1984), indicate that the Wrangellia terrane, the host terrane of the Nikolai Greenstone, is allochthonous to its present position in Alaska and that it has moved thousands of kilometers northward, relative to the North American craton, since Triassic time. The accretion of the Wrangellia terrane, as part of the Talkeetna superterrane, to the ancient North American Continent is interpreted to have taken place in about mid-Cretacoue time (Csejtey and others, 1978, 1982; Csejtey and St. Aubin, 1981).

$\mathrm{kPm}$ Metasedimentary rocks sequence (Middle Triassic to Late Pennsylvanian?)- These metasedimentary rocks are part of the Wrangellia terrane, and they occur near the southeast corner of the quadrangle, south of the Talkeetna thrust fault. This sequence underlies the Nikolai Greenstone with an apparent unconformity, but it rests conformably on the andesitic volcanic rocks of unit PPV. The maximum thickness of this marine sequence is about $800 \mathrm{~m}$. The lower and principal part of the sequence, about 700 $\mathrm{m}$ thick, consists of black argillite with laminae and thin interbeds of volcanic sandstone; and lesser amounts of thin-bedded crinoidal limestone, apparently turbidite deposits, forming discontinuous interbeds as much as $10 \mathrm{~m}$ thick; and a few interbeds, several tens of meters thick, of mafic volcanic breccia. The upper part of the sequence, approximately $100 \mathrm{~m}$ thick, comprises gray-green, red, or black, thin-bedded radiolarian chert (Silberling and others, 1981a, 1981b). Numerous large dikes and sills, diabasic and gabbroic in composition, occur throughout the sequence. These dikes and sills appear to be feeders and the intrusive equivalents of the overlying Nikolai Greenstone. Further descriptions of the metasedimentary rocks of this unit (KPm) can be found in Silberling and others (1981a, 1981b) and in Smith (1981).

Thin-section studies indicate that unit $\mathrm{KPm}$ underwent an apparently single event of very low grade regional metamorphism, the intensity of which does not exceed the prehnite-pumpellyite metamorphic facies of Turner (1968).

In addition to the unidentifiable crinoid columnals, as much as $1.5 \mathrm{~cm}$ in maximum diameter, at several localities within and just outside the quadrangle, the limestones and cherts yielded conodont and radiolarian fossils, respectively, which range in age from Late 
Pennsylvanian or Early Permian to Middle Triassic (Silberling and others, 1981a, 1981b; Nos. 142-147, table 2).

Not enough is known of unit $\mathrm{kPm}$ to reliably speculate on its depositional environment. Probably it was deposited at moderate and (or) deep oceanic depths. perhaps along the flank of a Pennsylvanian volcanic arc, represented by the andesitic volcanic rocks of unit PPV, which became essentially inactive by Permian time (Richter and Dutro, 1975).

According to Silberling and others (1981a), the lower part of unit $\mathbf{R} P \mathbf{P m}$ probably is equivalent to part of the Slana Spur Formation of the Mankomen Group in eastem Alaska (Richter and Dutro, 1975), and the upper part is equivalent to the Eagle Creek Formation of the Mankomen Group of the same area

Andesitic volcanic rocks (Early Permian? and Pennsylvanian)-These rocks occur near the southeast corner of the quadrangle and are part of the oldest known rocks of the Wrangellia terrane in southern Alaska (Richter and Jones, 1973; Richter and Dutro, 1975: Jones and others, 1977). The unit comprises an over 2,000-m-thick sequence of gray-green massive volcanic flows, breccias, and subordinate volcaniclastic rocks, all of largely andesitic composition (Silberling and others, 1981a, 1981b).

No fossils were found in these volcanic rocks, thus their age assignment is based primarily on correlating them (Silberling and others, 1981a) with the Tetelna Volcanics, named and described in the eastem Alaska Range by Richter and Jones (1973), and by Richter and Dutro (1975). According to these workers, the Tetelna Volcanics represents a late Paleozoic volcanic arc of dominantly andesitic composition, which had becorne virtually inactive by Early Permian time

\section{PLUTONIC ROCKS}

Kgr Granitic rocks (Late and Early Cretaceous)These granitic rocks occur in a number of dominantly medium sized and generally discordant plutons, which appear to be restricted to the east half of the quadrangle, but to the north of the Talkeetna thrust. The most common rock type is tonalite, but granodiorite, quartz diorite, diorite, and quartz monzodiorite also occur (granitic rock nomenclature according to IUGS, 1973). The more felsic rock types in most cases appear to be the result of differentiation. The typical tonalite, forming the bulk of the Cretaceous plutons, especially the larger ones, contains very small amounts of potassium feldspar, generally between 0 to 7 modal percent, and the modal quartz content ranges from about 20 to 40 percent. The major mafic minerals are biotite and homblende, generally in about equal proportions. The color index ranges from about 10 to 38 , but commonly it is between 19 and 34 . Grain size ranges from medium to coarse, but fine-grained varieties, probably border facies, also occur. Texture is generally granitic. Most of the Cretaceous granitic rocks have a fairly to moderately well developed flow foliation. This flow foliation appears to be the most reliable criterion in the field to differentiate between the Cretaceous granitic rocks and the Tertiary ones. Some of the Cretaceous plutons south and southwest of the Susitna Glacier are migmatitic, displaying alternating bands rich in felsic or mafic minerals. As some of the potassiumargon age determinations suggest, to be discussed later, some of these felsic-rich bands may actually be lit-par-lit type intrusions of felsic magmas in Tertiary time.

The Cretaceous plutons of the quadrangle appear to have been emplaced at deeper levels of the earth's crust than the Tertiary granitic rocks, which display all the characteristics of epizonal plutons (nomenclature of zones of granite emplacement according to Buddington, 1959). The Cretaceous plutons are interpreted to have been emplaced in a transitional zone between the epizone and mesozone. The main reasons for this interpretation are as follows: the prevalence of primary foliation, the scarcity of border facies, the partly concordant contacts with the regionally metamorphosed country rocks, and the lack of myarolitic cavities, associated volcanic rocks, and aplitic dikes.

Potassium-argon age determinations on the Cretaceous granitic rocks (Nos. 7, 9-12, 33, $35,36,38,40,46,50$, and 51 , table 1) yielded a disparate range of latest Early Cretaceous to early Tertiary ages (about 105 to $49 \mathrm{Ma}$ ). Some of these early Tertiary ages are suspected to be the result of lit-par-lit, that is intricate intrusions of granitic magma into the Cretaceous plutons in early Tertiary time. This is especially suspected for the pluton just south of the Susitna Glacier (No. 38, table 1). However, the majority of the ages falling between roughly 50 to $70 \mathrm{Ma}$ appear to have been reset by a regional thermal event or events, perhaps caused by the widespread plutonic and volcanic activity in the Healy quadrangle in early Tertiary time. This is suspected even where the biotite and homblende ages are nearly concordant (for instance, Nos. 36 and 40 , table 1). The cause for resetting is especially convincing in areas near and just to the south of the south edge of the quadrangle, where foliated and 
deepseated, assumedly Cretaceous granitic rocks are intruded by shallow, that is epizonal Tertiary granitic rocks, or are in close spatial proximity to subaerial volcanic flows and tuffs of early Tertiary age. All these three rock types of disperse geologic environments yieided the same or nearly the same potassium-argon ages (Nos. 46, 47, 50, and 51, table 1 of this report; and Nos. 2 and 3. table 1 of Csejtey and others, 1978). On the geologic map of Csejtey and others (1978) map unit Tsmg at and around the location of the dated sample no. 3 of table 1 correlates with unit $\mathrm{Kgr}$ on the geologic map of this report, as has been determined by subsequent fieid checking. Reheating of some of the Cretaceous granitic rocks in Tertiary time, that is resetting their potassium-argon ages, is further indicated by the significantly discordant ages on a biotitehornblende mineral pair from the Cretaceous pluton just west of the Susitna Glacier (No. 35 , table 1). On the basis of the above considerations, the Cretaceous plutons are interpreted to have been emplaced, probably by a series of intrusions, during a period about 106 to 70 million years ago.

As mentioned previously, the Cretaceous plutons occur only in the east half of the Healy quadrangle, on both sides of the Hines Creek and McKinley faults, and are intruding a variety of regionally metamorphosed rock units, which were juxtaposed during an accretionary orogenic period (Csejtey and others, 1982) in about mid-Cretaceous time. Thus, the Cretceous plutons provide an upper age limit for the main phase of this orogeny. One of the plutons, about 102 to $95 \mathrm{Ma}$ (Nos. 10-12, table 1), intrudes the Hines Creek fault, and thus restricts the timing of significant movement, vertical and (or) horizontal, along the fault (Wahrhaftig and others, 1975). The roughly symmetrical distribution of the Cretaceous plutons across the McKinley fault is supportive of the interpretation that only limited horizontal displacements took place along the fault since about mid-Cretaceous time (Csejtey and others, 1982)

Kgrt Tourmaline-bearing granite (Late or Early Cretaceous)-Occurs in a small, irregularshaped, discordant pluton with associated small satellitic bodies, of a total surface area of about $2.5 \mathrm{~km}^{2}$, along Virginia Creek in the northeastern part of the quadrangle (Wahrhaftig, 1970b). The rock is a mediumto fine-grained, tourmaline-bearing granite with a granitic to seriate texture. The exact age of this intrusion (latest Early Cretaceous or Late Cretaceous) is not known with certainty, but it is assumed to be the same as that of the nearby Cretaceous granitic rocks, which do not contain tourmaline
KJum Ultramafic rocks (Early Cretaceous or Jurassic)-This unit consists of a dark greenish- or brownish-gray, coarse- to medium-grained, plagioclase-bearing ultramafic rock that occurs in a small, sill-like intrusive body within amphibolite-grade metamomhic rocks of unit $\mathrm{kCs}$, near the east edge of the quadrangle, just north of the McKinley fault. Thin-section studies indicate that the rock-forming minerals are olivine, phlogopite, pale-brown amphibole, subordinate clinopyroxene (possibly diopside), some orthopyroxene, opaque minerals, and a few interstitial grains of plagioclase. The olivine forms small, rounded crystals, which are poikilitically enclosed in phlogopite, amphibole, and less frequently, in clinopyroxene. The plagioclase has the approximate composition of andesine and occurs in very small amounts as small, interstitial grains. The overall texture of the rock appears to be transitional between igneous and metamorphic.

The origin of this rock is poorly understood. Its unusual mineral assemblage, especially the high volume of phlogopite, makes it hard to place it into any rock classification scheme. Undoubtedly, it is a plagioclase-bearing ultramafic rock of igneous origin, most probably the differentiation product of a more felsic magma. The intrusion of this body appears to have preceded the regional metamorphism of the Upper Triassic country rocks.

The age of this ultramafic rock is imprecisely known. It is younger than the Upper Triassic country rocks, but appears to be older than the approximately mid-Cretaceous regional metamorphism of these same country rocks

Jgb Alkali gabbro (Late Jurassic)-Rocks of this unit occur in a small, discordant pluton, about 5.2 $\mathrm{km}^{2}$ in surface area, in the Clearwater Mountains near the southeast comer of the quadrangle. The rocks comprise an extremely heterogeneous subsilicic fractionation series of alkali gabbros, ranging from mafic theralites through essexites and monzogabbros into monzodiorites and monzonites (Smith, 1981; plutonic rock nomenclature according to IUGS, 1973). The most common rock type is a coarse- to medium-grained, dark greenishgray homblendic monzogabbro. The emplacement of the pluton predates the prehnite-pumpellyite facies regional metamorphism of the flyschlike country rocks of unit KJf. Hence, the metamorphism has obscured to some extent the original igneous textures.

Potassium-argon age determinations on biotite and hornblende mineral pairs from a sample of alkali gabbro yielded discordant ages (132 and $146 \mathrm{Ma}$, respectively), in- 
dicating that the pluton is latest Late Jurassic in age (Smith, 1981; No. 41, table 1).

A detailed description of the alkali gabbros, including their petrochemistry, can be found in Smith (1981, p. 37-39)

Dmg Metagabbro (Late Devonian?)-This is a dark greenish-gray, fine- to medium-grained, wellfoliated rock that underwent the same greenschist facies regional metamorphism (metamorphic nomenclature after Turner, 1968) as the surrounding country rocks of unit Pzp€p. Field relations suggest the rock is a metamorphosed igneous rock and has been interpreted to be a metagabbro (Wahrhaftig, 1968). The metagabbro occurs in two small, irregular-shaped intrusive bodies within the Precambrian(?) and early Paleozoic metamorphic rocks of unit $\mathrm{A}_{2 p} \hat{E}_{p}$. One of the plutons is located in the north-central part of the quadrangle, the other in the northeastern part.

Thin sections indicate the metagabbro to consist of epidote, chlorite, quartz, sericite, calcite, albite(?), and opaque minerals (Wahrhaftig, 1968). The greenschist-facies regional metamorphism has obliterated the original mineralogy and igneous texture.

The age of the metagabbro is uncertain. The metagabbro may be the intrusive equivalent of the metabasalts of unit Dmb, and thus be of Late Devonian age. But it is also possible that the metagabbro correlates with the Jurassic to Early Cretaceous gabbroic intrusive rocks within the Yanert Fork sequence (Dy) and within the Upper Triassic calcareous sedimentary rocks unit ( $\mathrm{kCs}$ ), all these rocks occuning south of the Hines Creek fault

\section{SOUTHWESTERN AND WEST-CENTRAL AREAS OF HEALY QUADRANGLE SEDIMENTARY AND VOLCANIC ROCKS \\ Ohio Creek area (Chulitna district)} Cretaceous and Late Jurassic)-These rocks occur in thrust slivers, sandwiched between Triassic and Jurassic strata of units $\mathrm{K} / \mathrm{b}$ and JKrs, in the southwestern part of the quadrangle. The unit consists of dark-gray argillite, dark-gray to greenish-gray bedded chert, thick-bedded gray sandstone, thinbedded gray sandstone, and rare thin beds of shelly limestone. Both Late Jurassic and Early Cretaceous radiolarians were obtained from the chert. The thick-bedded sandstone contains fragments of Inoceramus $\mathrm{sp}$. of Hauterivian to Barremian age, and some of the limestone beds contain Buchia sublaevis of Valanginian age (for fossil descriptions, see Nos. 28-31, table 2). Sorne of the thin- bedded sandstone contains abundant detrital white mica. Thicknesses and the stratigraphic relations within these rocks and with adjacent rocks are unknown because of complex folding and faulting and poor exposures. The age range and lithologies of the rocks of unit $\mathrm{KJa}$ tentatively suggest that these rocks might be tectonically emplaced distal facies of the flyschlike rocks of unit $\mathrm{KJf}$.

The metamorphic grade of these rocks is unknown, but it appears to be no higher than the prehnite-pumpellyite metamorphic facies of Tumer (1968).

More detailed descriptions of these rocks are given in Jones and others (1980)

JKrs Red and brown sedimentary rocks and basalt (Early Jurassic and Late Triassic)-Unit occurs in thrust slivers near the southwest corner of the quadrangle. The maximum preserved thickness of these rocks is greater than $2,000 \mathrm{~m}$. The basal part of the unit consists of a red-bed sequence of sandstone, siltstone, argillite, and conglomerate, with a few thin interbeds of brown fossiliferous sandstone, pink to light-gray dense limestone, and intercalated basalt flows. This red-bed sequence grades upward into highly fossiliferous brown sandstone, which in turn grades upward into brownish-gray siltstone with yellowish-brown limy concretions.

Clasts in the red beds are dominantly basalt grains and pebbles that probably were derived from basalt flows of unit $\mathrm{Klb}$, that lies unconformably below the red beds, and from the basalt flows within the red-bed sequence. Subordinate amounts of the clasts consist of white, in part foliated, metaquartzite pebbles; flakes of white mica which, along with the metaquartzite, must have been derived from an unidentified siliceous metamorphic terrane; and red radiolarian-chert pebbles and grains, which probably were derived from the ophiolitic rocks of unit Dsb. No other clasts that can be identified as coming from the ophiolitic rocks have been recognized.

Fossils from the limestone and the overlying brown sandstone are of Late Triassic age, and those from the yellowish-brown limy concretions are of Late Triassic and Early Jurassic age (Nos. 107-114, table 2).

Most of this unit appears to have undergone very low grade regional metamorphism. Judging by the metamorphic mineral assemblages in the underlying basalts of unit Flb, the metamorphic grade of the red and brown sedimentary rocks and basalt unit (JKrs) probably does not exceed the prehnite-pumpellyite facies of Turner (1968).

More detailed discussions of both the red and brown beds, and their detailed distribution in the Healy A-6 quadrangle, can be found in 
Jones and others (1980)

Limestone and basalt sequence (Late Triassic; Norian?)-Interlayered sequence, at least several hundreds of meters thick, of limestone, partly recrystallized to marble, and flows of altered amygdaloidal basalt. Individual units are as much as several tens of meters thick. These rocks occur in a complexly thrustfaulted zone in the southwest corner of the quadrangie. The limestone and basalt sequence unconformably underlies unit $\mathrm{Jkrs}$. The base of the sequence is not exposed.

The limestone is medium gray, massive to thick bedded, but locally it has altered to fineto medium-grained marble. Several of the limestones contain sparse fragments of poorly preserved corals and thick-shelled megalodontid bivalves as much as $20 \mathrm{~cm}$ in length. A single specimen of Spondylospira(?) sp., in conjunction with the megalodontid bivalves, suggests a probable Norian age for the sequence (Jones and others, 1980; Nos. 115117, table 2).

The amygdaloidal basalt is dark gray to greenish gray, aphanitic, with numerous amygdules. Locally, it displays well-developed pillow structures. Primary rock-forming minerals are fine-grained labradorite, titaniumrich augite, and opaques in an originally intersertal or subophitic texture. The original mineral assemblage has been more or less altered to an aggregate of chlorite (much of it after glass), epidote, calcite, sericite, and some zeolite, probably prehnite. The amygdules consist of chlorite, calcite, prehnite, and minor quartz. Most of the secondary minerals are probably the result of deuteric alteration, but some are the product of prehnite-pumpellyite facies regional metamorphism (metamorphic nomenclature after Tumer, 1968). Fifteen chemical analyses of least altered basalt samples indicate that the basalts are somewhat low in silica (normalized $\mathrm{SiO}_{2}$ contents average 46.7 percent by weight, ranging from 43.7 to 48.7 percent), high in alkalis (normalized $\mathrm{Na}_{2} \mathrm{O}$ contents average 3.06 percent by weight, ranging from 1.3 to 5.2 percent; and normalized $\mathrm{K}_{2} \mathrm{O}$ contents average 0.47 weight percent, ranging from 0.07 to 1.5 percent), and are high in titanium (normalized $\mathrm{TiO}_{2}$ contents average 3.8 weight percent, ranging from 2.5 to 5.0 percent). The chemistry and mineralogy suggest that these basalts had alkali affinities prior to alteration.

The fossils and the lithologies of the limestones and the basalts indicate shallowwater marine deposition. The probable alkali affinity of the basaits further suggests that they etther were part of an ocean island shield volcano, perhaps associated with a barrier reef, or that they were formed on a

continental margin

$\mathrm{kr}$

Red beds (Late Triassic)-These red beds occur in thrust slivers along Long Creek and around Lookout Mountain near the southwest corner of the quadrangle. The maximum preserved thickness of these rocks is estimated to be about $500 \mathrm{~m}$. The red beds consist of red sandstone, siltstone, argillite, and conglomerate similar to the red beds of unit J $\mathrm{krs}$. Clasts of gabbro, serpentinite, and fossiliferous Permian(?) limestone are present in these rocks but have not been identified in unit JFrs. Also, a thin conglomerate bed containing angular clasts of rhyolite is locally present at the base. These red beds lie with depositional unconformity on Upper Devorian to Lower Triassic strata of unit KDV. The top of the red beds section is nowhere exposed. The red beds lack fossils and, therefore, have not been dated, but they are assumed to be equivalent in age to the Upper Triassic red beds of unit Jkrs (Jones and others, 1980). The metamorphic grade of the red beds of unit $\mathbf{k r}$ is not known, but it is assumed to be that of the prehnite-pumpellyite facies of Turner (1968), the same as that of the surrounding rocks of the region

RDV Volcanogenic and sedimentary rocks (Early Triassic to Late Devonian)-These rocks occur in several thrust slivers around Lookout Mountain in the southwestern part of the quadrangle. They comprise an heterogeneous, intercalated sequence, over $500 \mathrm{~m}$ thick, of greenish-gray to black tuffaceous chert, volcanic conglomerate, lesser amounts of maroon volcanic mudstone, breccia composed largely of basaltic detritus, laminated flyschlike graywacke and shale, large lenses of lightgray, thick-bedded limestone, and poorly exposed thin beds of ammonite-bearing limestone. Ammonites and conodonts from the arnmonite-bearing limestone are Early Triassic in age; fossils from the thick-bedded limestone are Permian in age; brachiopods from the conglomerate are also of Permian age; and fossils from the chert are Late Devonian and Carboniferous in age (Nichols and Silberling, 1979; Jones and others, 1980; Nos. 129-136, table 2). The stratigraphic and structural relations between these diverse rocks are obscured by numerous folds and faults and by poor exposures.

The metamorphic grade of these rocks is not known, but it is probably that of the greenschist metamorphic facies of Turner (1968).

Detailed discussions of these rocks are given in Nichols and Silberling (1979) and in Jones and others (1980)

Serpentinite, basalt, chert, and gabbro (Late 
Devonian-These rocks comprise a tectonically intermixed assemblage, a few hundreds of meters thick, that forms a northeast-trending belt of thrust slivers in the southwest corner area of the quadrangle. Sheared serpentinite is the most abundant rock type; the remaining component rocks occur in various proportions in lenticular and podiform tectonic blocks as much as several hundred meters in extent. Many chert lenses occur intercalated with basalt flows, which locally show poorly preserved pillow structures. Rocks of this unit have been previously described and interpreted as a dismembered ophiolite assemblage by Clark and others (1972) and by Jones and others (1980).

The serpentinite is dark gray to dark greenish gray, always sheared, and consists almost entirely of clinocrysotile and lizardite with subordinate brucite, talc, and chromite. Sparse relict olivine crystals and a bastite texture suggest that the serpentinite originally was a pyroxene-olivine ultramafic rock.

The basalt is dark gray, aphanitic to fine grained with a few phenocrysts, as much as 4 $\mathrm{mm}$ in maximum dimension, of altered plagioclase, pyroxene, and olivine. The rock is locally vesicular or amygdaloidal and generally is fragmental; many of the fragments are palagonite. Some of the vesicles and amygdules are concentrated along spherical surfaces, which may be parts of pillow structures. Depositionally intercalated marine chert beds further indicate that the basalts were formed as submarine flows.

The chert is generally red, but reddishbrown and greenish-gray varieties also occur. It is commonly in beds a few millimeters to a few centimeters in thickness and contains abundant radiolarians.

The gabbro is medium to dark greenish gray, fine to coarse grained, and is composed of altered plagioclase, pyroxene, olivine, and opaques. Compositional layering, interpreted to be cumulative textures, is common, and the layers range in thickness from a few millimeters to a few centimeters. The best exposed gabbro occurs in a lens about $100 \mathrm{~m}$ thick and about $1 \mathrm{~km}$ long on the ridge north of the unnamed northern branch of Shotgun Creek.

Age determinations of radiolarians and conodonts in chert samples from five separate localities reliably indicate a Late Devonian (Fammennian) age for the ophiolitic rocks (Jones and others, 1980; Nos. 137-141, table 2)

Flysch and associated rocks southwestern part of the quadrangle. Lithologically they are identical to the flyschlike rocks of unit KJf, and are considered to be part of the more or less autochthonous Jurassic and Cretaceous flysch sequence interpreted to have been deposited on and between the ancient North American Continent and the converging Talkeetna superterrane (Csejtey and others, 1982). This unit is shown separately on the geologic map because, in addition to Early Cretaceous fossils, it has also yielded fossils of earliest Late Cretaceous (Cenomanian) age (Nos. 32-36, table 2). None of the other flyschlike rocks of the quadrangle have yielded fossils of such a young age, but perhaps this is the result of intense, post-depositional deformation and subsequent erosion. Conglomerates of unit $\mathrm{KJfl}$ also contain limestone pebbles of early Paleozoic age (Nos. 37 and 38, table 2)

J̧ta Crystal tuff, argillite, chert, graywacke, and limestone (Late Jurassic to Late Triassic?) Moderately deep to deep marine sequence, tightly folded and internally faulted, at least several thousand meters thick. These rocks are interpreted to occur in a large thrust block along the western slope of the Upper Chulitna Valley, in the southwest part of the quadrangle. Four-fifths of the sequence is comprised of the massive, cliff-forming crystal tuff, while the remaining rocks form only a narrow outcrop belt aiong the western margin of the unit. The contact between these two groups of rocks may be tectonic.

The crystal tuff is light to dark gray, locally with a greenish tint, and weathers to various shades of brown. It is massive with obscure rhythmic laminations and thin bedding. The tuff is composed of abundant small feldspar crystals (albite?) set in a very fine grained matrix of devitrified volcanic glass in which some shards can be recognized. Sparse but unidentifiable fragments of radiolarians were also found. $A$ thin interbed of volcaniclastic sandstone yielded the following fossils: Arctoasteroceras jeletskyi, Paltechioceras (Orthechioceras?) sp., and Weyla sp. (Jones and others, 1980). According to R.W. Imlay of the U.S. Geological Survey (written commun. to D.L. Jones, 1976), these fossils indicate a late Sinemurian age (Early Jurassic; No. 70, table 2). As the Sinemurian fossils come from near the top of the several thousand-metersthick crystal tuff section, the base of the section may be as old as Late Triassic(?).

The argillite, chert, graywacke, and limestone occur interbedded in various proportions in individual units as much as several tens of meters thick. The argillite and chert are dark gray to black; the graywacke is medium to dark gray, very fine to medium 
grainded, locally with graded bedding. The limestone is medium gray, generally phosphatic, in part sandy, locally is associated with limy siltstone and conglomerate; forms blocks and lenticular beds as much as several kilometers in extent. Some of the cherty beds yielded radiolarians of Callovian to early Tithonian age (Late Jurassic; Nos. 68 and 71, table 2), and at five different localities, the limy rocks yielded Early Jurassic ammonite faunas of early Sinemurian age (Jones and others, 1980; Nos. 64-67, and 69, table 2).

The moderately deep to deep marine rocks of unit Jkta are dissimilar in lithologies, depositional environment, and partly in age to the surrounding rock units. Perhaps unit Jkta represents the tectonically emplaced remnants of deep oceanic sediments, which were deposited in a large oceanic basin between the ancient North American Continent and the northward drifting Talkeetna superterrane (Csejtey and others, 1982). Accordingly, the Upper Jurassic rocks of unit JTta are the distal oceanic basin equivalents of the Jurassic part of the flyschlike rocks of unit KJf. If this interpretation is valid, then it also implies that the Talkeetna superterrane must have accreted to the ancient North American Continent in post-Jurassic time, because during the Jurassic the converging continents were still separated by a large oceanic basin

\section{Rocks of unknown terrane affinity} Triassic; late Norian)-These rocks occur in small cutbank exposures along the Jack River in the central-western part of the quadrangle. They are interpreted to be part of a small thrust sliver. According to rock types, the conglomerate and volcanic sandstone unit $(K \mathrm{cg})$ can be subdivided into three parts (Jones and others, 1980). The lower part of the section, about 40 to $50 \mathrm{~m}$ thick, comprises cobble to boulder conglomerate composed of green volcanic rocks and red, radiolarian chert. The chert clasts are well rounded; some are as much as $30 \mathrm{~cm}$ in diameter. Radiolarians from the red-chert clasts were determined to be Permian in age (unpub. data, D.L. Jones and B.K. Holdsworth in Jones and others, 1980). Thus, the red-chert clasts of this unit could not have derived from the Devonian red cherts of unit Dsb. Their source area is unknown. The middle part of the section, about 40 to $50 \mathrm{~m}$ thick, comprises finer grained volcanogenic (andesitic?) conglomerate with locally abundant fossils of Heterastridium sp., indicating a Late Triassic (late Norian) age (No. 118, table 2). The upper part of the section consists of about 50 $\mathrm{m}$ of massive volcanic sandstone.
The lithologic characteristics of unit $\mathrm{k} \mathrm{cg}$ are markedly different from those of any other rocks occurring in the quadrangle. However, the fossil Heterastridium sp., of late Norian age, has also been found in unit Kvs. On this basis, and on the basis that volcanogenic rocks and cobble conglomerates also occur in unit KVs, a possible correlation between these units is provisionally suggested. Perhaps the difference in the clast compositions of the conglomerates is the result of facies changes and (or) different source areas. Accordingly, unit $\mathrm{K} c \mathrm{cg}$ might be part of the Wrangellia terrane of the Talkeetna superterrane

\section{Nixon Fork terrane}

DOs Sedimentary sequence (Middle Devonian to Ordovician)-Sequence occurs in the westcentral part of the quadrangle, north of the McKinley fault. Previously, these rocks have been referred to by Jones and Silberling (1979) and by Jones and others (1981a, 1982, 1983, and 1984) as the Dillinger (tectonostratigraphic) terrane. As will be discussed later in this report, this sequence is correlated here with the deep-water facies "shale-out" beds of the Nixon Fork terrane (Churkin and others, 1980; Dutro and Patton, 1982).

Unit DOs comprises a complexly folded and faulted, regionally metamorphosed, intercalated, and a stratigraphically upwardshallowing marine sequence of dominantly slope and basinal turbidites and hemipelagic deposits with lesser amounts of shelf-type deposits. The sequence consists of medium- to dark-gray, thinly graded bedded to laminated, medium- to fine-grained sandstone; dark-gray to black argillite; intercalated layers, a few tens of meters thick, of dark gray, generally thinly bedded, locally thick-bedded limestone and dark-gray argillite; and near the top of the section an approximately 200 -m-thick interbed of medium- to light-gray, massive, finely to medium-crystalline, partly dolomitic limestone. This massive limestone interbed near the top of the section is shown separately on the geologic map by the map-unit symbol "Is".

The sandstones contain grains of mica and feldspar, in addition to abundant quartz and quartzitic grains, suggesting a continental source (Jones and others, 1982). The thinly bedded limestone and argillite interlayers also appear to be turbidites (Jones and others, 1982) deposited in a continental-slope and deep-marine basin environment. The massive limestone (Is) appears to have been deposited in a shallow carbonate-shelf and shoreline environment. This is indicated by the presence of dolomitic limestones with algal laminations, mud cracks, intraformational breccias, and 
birdseye structures, which typically form in tidal-flat environments of restricted platforms.

At one locality (No. 170, table 2), one of the thinly bedded limestones yielded gastropod fossils of Ordovician to Devonian ages (E.L. Yochelson and J. Pojeta in Jones and others, 1983). From the headwater area of the Sanctuary River, Capps (1932, p. 255; No. 169, table 2) reported Middle Devonian fossils from the massive limestone interbed (Is). Samples from two localities in the massive limestone (Nos. 165 and 168, table $2)$, and two from thinly bedded limestones (Nos. 166 and 167, table 2), were processed for conodonts, but none were found. However, a more extensive sampling of both the massive and the thinly bedded limestones most probably would yield identifiable conodonts, because specimens were found in limestone pebbles from the nearby, stratigraphically overlying clastic rocks of the Cantwell Formation (Tcs). These Cantwell pebbles consist of both massive and thinly bedded limestones, which lithologically are identical to the massive limestone (Is) and the thinly bedded limestones of unit DOs. The Cantwell conodont-bearing limestone pebbles almost certainly were derived from less recrystallized limestones of unit DOs, including the massive limestone interbed (Is). The conodonts from the Cantwell limestone pebbles (Nos. 9-11, table 2) range in age from Ordovician to Early Devonian. On the basis of the above fossil data, unit DOs is considered to range in age from Ordovician to Middle Devonian and the massive limestone interbed (Is) is considered to be of Middle Devonian age.

The metamorphic grade of unit DOs, including the massive limestone interbed (is), is not known. On the basis of field observations, it is estimated to be probably not higher than the prehnite-pumpellyite metamorphic facies of Turner (1968).

The lithologic characteristics of unit DOs, including the massive limestone interbed (Is), suggest that it is a continental margin-type deposit representing a stratigraphically upward-shallowing marine sequence, which was deposited at water depths ranging from deep to very shallow.

The age range and the lithologies of unit DOs, including the massive limestone interbed (Is), are dissimilar to those of any other map units in the Healy quadrangle. Jones and others (1981a, 1982) correlated unit DOs, including the massive limestone interbed (Is), and its westward extensions in the McKinley quadrangle, with similar rocks about $100 \mathrm{~km}$ to the southwest, underlying large areas south of the Denali fault system. They designated both of these rock sequences as the Dillinger terrane. However, Dutro and Patton (1982) provisionally considered the Dillinger terrane south of the Denali fault system to be at least partly correlative with deep-water facies strata of the Nixon Fork terrane. Unit DOs, including the massive limestone interbed (Is), in the Healy quadrangle is very similar in its age range and lithologies to the deep-water facies rocks and some of the shallow-water facies rocks of the Nixon Fork terrane described by Dutro and Patton (1982) and by Churkin and others (1980). On this evidence, unit DOs, including the massive limestone interbed (Is), of the Healy quadrangle is considered to represent a section of the deep-water and part of the shallow-water segment of the Nixon Fork terrane. This terrane appears to have been part of the ancient North American Continent in Cretaceous time, and possibly much earlier (Patton, 1978; Foster and Keith, 1974; H.L. Foster, U.S. Geological Survey, unpubl. data, 1980). The postulated subsurface extent of the Nixon Fork terrane, and the postulated tectonic processes, which emplaced fragments of the Nixon Fork terrane in the Healy quadrangle, will be discussed in more detail in the "Tectonics" section of this paper

Fysch and rocks of unknown terrane affinity

KJf Flysch sequence (Early Cretaceous and Late Jurassic)-These rocks are the same as the flyschlike rocks of unit KJf in the eastern and southern parts of the quadrangle. The reason that the flyschlike rocks are shown again in the correlation chart of map units (under the heading "Southwestern and west-central areas of Healy quadrangle") is to indicate that the flyschlike rocks of unit $\mathrm{KJf}$ in the central part of the quadrangie and north of the McKinley fault rest unconformably on the Upper Triassic rocks of unit $k \mathrm{db}$. Everywhere else in the quadrangle, the contact between the flyschlike rocks of unit $\mathrm{KJf}$ and all older rocks is either tectonic or is covered by surficial deposits. Fossil data for unit KJf in the western part of the quadrangle is given under Nos. 39-42, table 2

Kbd

Basalt, diabase, and subordinate sedimentary rocks (Late Triassic; Karnian and Norian)This unit and the depositionally underlying, and locally interfingering flyschlike rocks of unit $\mathbf{R P S}$ occur in a narrow and discontinuous, fault-bounded, east-trending belt in the west-central part of the quadrangle. Both units have been previously described and designated as part of the McKinley (tectonostratigraphic) terrane by Jones and others (1981a, 1982). 
The unit comprises a submarine sequence several hundred, perhaps several thousand meters thick of basalt flows, mostly pillowed, with associated sills and dikes of diabase and gabbro, which also cut the underlying rocks of unit $\mathbf{R}$ Ps. According to Jones and others (1982), most of the basalts are porphyritic, with phenocrysts of clinopyroxene, olivine, and magnetite. The subordinate interbedded sedimentary rocks are dark-gray to darkgrayish-green, fine-grained sandstone, siltstone, and argillite. Some of the these rocks contain abundant angular tuffaceous material. Fossils from this unit are rare, but an halobid bivalve of Late Triassic (Karnian to Norian) age was found at one locality, and radiolarians of Late Triassic (late Norian) age were recovered from a sample at another (Gilbert and others, 1984; Nos. 119 and 120, table 2).

The metamorphic grade of these rocks is imprecisely known, but probably is no higher than the prehnite-pumpellyite, possibly the lower greenschist facies of Turner (1968). This unit probably represents a series of subaqueous basalt flows and minor intercalated clastic and pelagic sediments, which were deposited in a deep marine environment. Some of the sediments were laid down synchronous with eruptions, as indicated by the abundance of angular tuffaceous materials. All the sediments are fine-grained, mainly thin bedded turbidites and pelagic mudstones, and they contain little or no continentally derived sand-sized grains, but they contain pelagic fossils. All these features indicate deposition in a deep marine environment.

The stratigraphic position of the basalts and the lithologies of the underlying flyschlike rocks of unit KPs are different from any other rock units within the quadrangle. Both units undoubtedly comprise a tectonically emplaced block of unknown origin. Interpretive geologic cross sections across the Healy quadrangle strongly suggest that the exposures of units $\mathrm{K}$ bd and KPs probably constitute upfaulted blocks of the North American continent, which is postulated to underlie, depositionally and (or) tectonically, the Jurassic and Cretaceous flyschlike rocks of south-central Alaska and upon which the Talkeetna superterrane is interpreted to have been obducted in midCretaceous time (Csejtey and others, 1982; also see the Structure and Tectonics sections of this report)

KPs Flyschlike sedimentary rocks (Late Triassic to Pennsylvanian)-This unit and the depositionally overlying and locally interfingering rocks of unit $\mathrm{kbd}$, as previously mentioned, occur in the west-central part of the quadrangle. Both units have been described and designated as part of the
McKinley terrane by Jones and others (1981a, 1982).

Unit KPs comprises an intensely folded marine sequence, estimated to be at least several hundreds of meters thick, of dark-gray to black, massive to thin-bedded, flyschlike rocks, namely, conglomerate, sandstone, siltstone, argillite, a few thin interbeds of impure limestone, and near the top of the sequence, thin interbeds of chert intercalated with argillite. These rocks contain abundant trace fossils, and some of the conglomeratic layers contain displaced fossiliferous detritus such as bryozoans, echinoderm fragments, rare brachiopods of Carboniferous to Permian age and some corals of Devonian and probable Mississippian age (Jones and others, 1982; Sherwood and Craddock, 1979; Nos. 123-125, table 2). Slump blocks of crinoidal limestone, as much as $1 \mathrm{~m}$ in diameter, occur locally in the upper part of the sequence. The source of these blocks is not known, but a sample from one block yielded conodonts of late Early to early Middle Devonian age (No. 126, table 2)

The age of this unit is considered to range from Pennsylvanian to Late Triassic. Conodonts and radiolarians extracted from chert samples from near the top of the sequence indicate a Late Triassic (Karnian) age (Nos, 121 and 127, table 2), and conodonts from a calcareous layer in a sandstone and argillite section indicate a Middle Triassic (Anisian) age (No. 122, table 2). The Pennsylvanian age determination is based on a collection of brachiopods reported on by L.R. Laudon in Sherwood and Craddock (1979. see also No. 128, table 2 of this report).

The metamorphic grade of these rocks is imprecisely known, but is most likely of the prehnite-pumpellyite facies, possibly of the low green-schist facies of Turner (1968)

The depositional environment of this unit appears to have been at slope to base of slope water depths, and the unit appears to represent a deepening-upward sequence (decrease in grain size stratigraphically upward). This is indicated by the conglomerates and thick-bedded turbidites (sandstone, siltstone, and argillite) near the base of the sequence, which grades upward into interbedded chert and argillite near the top of the sequence. The displaced fossiliferous blocks and clasts were undoubtedly derived from preexisting basement rocks and possibly from a contemporaneous carbonate platform at shallower depths. A massive conglomerate layer, which contains Devonian, Mississippian, and Permian fossil clasts (Nos. 123 and 214, 
table 2). also contains large basalt clasts. implying an original depositional relation with the associated basalts of unit $\mathrm{k}$ bd (Jones and others, 1982).

The possible regional correlation of this unit has already been discussed briefly under the description of unit $\mathbf{k}$ bd

\section{Tectonic melanges}

Melange south of McKinley fault (Late and (or) Early Cretaceous)-Unit occurs in a southeast-trending, discontinuous, faultbounded outcrop belt in the southwestern part of the quadrangle. Previously, the unit has been described by Jones and others (1980. 1981a, 1982) as the Broad Pass (tectonostratigraphic) terrane composed of Paleozoic rocks. In this report, the unit is reinterpreted as a tectonic, and probably sedimentary melange, comprising Paleozoic and upper Mesozoic rocks. This melange probably formed sometime during, and as a result of, the accretion of the Talkeetna superterrane to the ancient North American Continent in mid-Cretaceous time (Csejtey and others, 1982). The unit includes three distinct rock suites, which are intensely deformed, sheared and have been intricately intermixed by tectonic and perhaps also by sedimentary processes. These rock suites are:

(1) Medium- to thin-bedded, greenish-gray to tan-colored, locally black, cherty tuff, chert, argillite, and fine-grained volcanic sandstone. Commonly, the bedding shows slight grading from fine sand-sized grains at the bottom to argillite at the top. Locally, vitroclastic textures in the tuffs are well developed (Jones and others, 1980).

(2) Dark-gray to black, flyschlike rocks of argillite, slate. shale, fine- to medium-grained graywacke. subordinate bedded chert, and both chert-pebble and polymictic conglomerates. Lithologically, these rocks are identical to the flyschlike rocks of units KJf, $\mathrm{KJfl}$, and $\mathrm{KJ} \mathrm{Jk}$.

(3) Lenses and elongate blocks, some as much as several kilometers in length, of medium-gray, generally medium bedded and rarely massive, fine- to medium-grained fossiliferous limestone.

The lenses and blocks of limestone are shown separately on the geologic map by the map-unit symbol "msl".

Radiolarians and conodont fragments from the cherty tuffs and associated rocks range in age from Late(?) Devonian to Mississippian (Nos. 44, 48-51, table 2). Megafossils and conodonts from the limestones range from Silurian to Middle Devonian in age (Nos. 43, $46,47,52-54$, table 2). The flyschlike rocks did not yield any fossils, with one possible exception of a chert sample that yielded a single Parasaturnalidae fragment of Mesozoic age (No. 45, table 2). However, according to N.R.D. Albert (U.S. Geological Survey; written commun., 1982), this single radiolarian fragment could be the result of contamination during sample processing.

A melange origin for this unit is supported by the following evidence: all contacts of the limestone lenses and blocks with their enveloping rocks are faults; the limestones appear to be shallow-water bioherm (patchreef) and related carbonate deposits, whereas many of the envoloping rocks are deeper water turbidites; the occurrence of flyschlike rocks whose Jurassic(?) and Cretaceous(?) age is based primarily on lithologic correlation; and the intricately intermixed occurrence of the three disparate rock suites. The fact that the age of the flyschlike rocks is based primarily on lithologic correlation with units $\mathrm{KJf}, \mathrm{KJfI}$, and $\mathrm{KJfk}$, without reliable fossil evidence, makes the melanage interpretation somewhat uncertain. However, fossils are scarce in the flysch units everywhere in the quadrangle. The best exposure showing the relation of a limestone lens to the enveloping flyschlike rocks of Jurassic(?) and Cretaceous(?) age is in a road cut on the north side of the Denali Highway, about $1.8 \mathrm{~km}$ east of the new part of the town of Cantwell (No. 47, table 2). On the basis of the above evidence, the melange interpretation is strongly favored in this report.

The source and mode of origin of the Paleozoic components of the melange, and the actual developmental process of the melange, are poorly understood. It is herein postulated that the Paleozoic rocks were intermixed with the parautochthonous flyschlike rocks primarily by complex thrusting in mid-Cretaceous time, shortly preceeding and (or) during the accretion of the Talkeetna superterrane to the ancient North American Continent (Csejtey and others, 1982). According to this concept, the flyschlike rocks were deposited in the narrowing oceanic basin between, and lapping onto, the approaching continents. As a result of the continental collision, the flyschlike basin collapsed, and the Talkeetna superterrane was thrust upon, that is obducted upon, the margin of the ancient North American Continent, which by that time included the Nixon Fork and YukonTanana terranes. The collision was accompanied by complex thrusting and folding not only of the rocks of the Talkeetna superterrane and the flysch basin, but also of the ancient North American Continent. It also is postulated that prior to the continental collision the rocks of the Nixon Fork terrane extended under the onlapping flyschlike rocks, and south of the Yukon-Tanana terrane, much 
farther northeast than shown by Jones and others (1981a). During deposition of the flysch, submarine slump blocks of Paleozoic strata from the Nixon Fork terrane, especially its eastward "shale-out" beds (Churkin and others, 1980), could have been incorporated into the flysch. During the process of continental accretion and accompanying orogenic deformation, these depositional melanges may have been further deformed, intermixed, and transported northwestward as a unit by complex thrusting and folding. One problem in this concept is the somewhat tenuous correlation of the Paleozoic rocks in the melange with rocks of the Nixon Fork terrane. Whatever the origin of the Paleozoic rocks, the concept of this unit ( $\mathrm{Kms}$, including subunit $\mathrm{msl}$ ) as a late Mesozoic melange appears to be viable

Kmn Melange north of McKinley fault (Late and (or) Early Cretaceous)-This unit occurs in a fewkilometers-wide but elongated fault sliver just north of the McKinley fault, in the west-central part of the quadrangle. Previously, the unit has been described by Jones and others (1981a, 1982) as the Windy (tectonostratigraphic) terrane, comprising Paleozoic and Mesozoic rocks. In this report, the unit is interpreted as a tectonic, and possibly, sedimentary melange of Early and (or) Late Cretaceous age. The unit comprises four disparate, intricately intermixed and pervasively sheared rock suites:

(1) Blocks of medium-gray, mediumgrained, massive limestone of Silurian(?) and Devonian age; (2) blocks of medium-gray, medium-grained, massive limestone of Late Triassic age; (3) dark-gray to black flyschlike rocks, namely sandstone, argillite, and subordinate chert pebble and polymictic conglomerate, all of which are correlative with units $\mathrm{KJf}, \mathrm{KJfl}$, and $\mathrm{KJfk}$; and (4) a poorly exposed small fault sliver of serpentinized ultramafic rock, altered basalt, green and maroon tuff, and recrystallized chert, all of unknown age, possibly comprising an ophiolitic assemblage (Jones and others, 1982).

The two kinds of limestones are shown separately on the geologic map by the mapunit symbol " $\mathrm{mnl}$ ", and the ophiolitic(?) rocks by the map-unit symbol "mno".

Available fossil data for this unit are summarized under Nos. 55-63, table 2.

The intricate intermixing of the limestone blocks of two different ages, and of the ophiolitic(?) rocks, with the Jurassic and Cretaceous flyschlike rocks strongly indicates that this unit $(\mathrm{Kmm}$, including subunits $\mathrm{mnl}$ and $\mathrm{mno}$ ) is a tectonic, and possibly sedimentary, melange. This is further indicated by the pervasively sheared nature of this unit and by the fault contacts of the limestone blocks with the enveloping rocks.

The time, method, and the tectonic setting of the development of this melange unit, although imprecisely known, is considered to be the same or very similar to that of the melange unit south of the McKinley fault ( $\mathrm{Kms})$, and for a discussion the reader is referred to the description of that unit. The Silurian(?) and Devonian limestone blocks may be tectonically displaced fragments of the Nixon Fork terrane, but the source of the Upper Triassic limestones is an enigma. Possibly, these limestones originated in the Upper Triassic section ( $\mathrm{k} \mathrm{cs}$ ) of the YukonTanana terrane. Because of the complete lack of any relevant information, no attempt is made here to speculate on the age and origin of the ophiolitic(?) rocks.

In spite of the uncertain origin of many of its rock components, available evidence strongly indicates that this unit $(\mathrm{Kmm}$, including subunits $\mathrm{mnl}$ and $\mathrm{mno}$ ) is an Early and (or) Late Cretaceous melange, which developed primarily by tectonic, and possibly, by sedimentary processes. This melange unit north of the McKinley fault has been mapped separately from the melange unit south of the fault because of the differences between some of the rock components of the two units, and because of the apparently different structural positions of the two units, suggested by geologic cross sections across the Healy quadrangle.

\section{STRUCTURE}

The rocks of the Healy quadrangle and surrounding regions have undergone complex and intense thrusting, folding, high-angle reverse and normal faulting, shearing, and differential uplifting, with associated regional metamorphism and plutonism. At least two major periods of deformation are recognized: a mid- to Late Cretaceous alpine-type orogeny with penetrative deformation, interpreted to be the result of northwestward plate motions and subsequent accretion of the Talkeetna superterrane to the ancient North American continent (Csejtey and others, 1982) and a period of nonpenetrative deformation of normal and high-angle reverse faulting, generally open folding, and uplifting of the already accreted continental margin in late Tertiary and Quaternary time. Structural cross sections across the Healy quadrangle, constructed on the basis of all available geologic and geophysical data, suggest that at least in this region of Alaska the midCretaceous accretionary orogeny actually took place in two stages: First, the original continental margin was shortened by northwestward underthrusting, and second, the Talkeetna superterrane was obducted onto, that is, thrust over this already deformed continental margin.

Many of the major structural features of the quadrangle and adjacent areas are the result of the Cretaceous 
accretionary orogeny, which produced the dominantly northeast- and east-trending structural grain of the region. The beds generally dip steeply, and the vergence of this structural grain is mostly toward the northwest and north, but in many parts of the quadrangle, especially to the north, it is toward the southeast or the south. The reverses in the structural vergence generally are abrupt; a good example is in the Chulitna River area near the southwest corner of the quadrangle. East of the river, a stacked thrust sequence, consisting of (ascending) units KJf, Kvs, and $\mathrm{KJ} \mathrm{Jk}$, has been folded into giant westward-overturned megafolds with estimated minimum amplitudes of about $10 \mathrm{~km}$; however west of the river, a sequence of imbricate thrust sheets has been compressed into a southeastwardoverturned synform (figs. 5 and 6 in Csejtey and others, 1982; cross section $A \cdot A^{\prime}$ of this report). In the above case, the abrupt reversal of the structural vergence is interpreted to be the result of local stress reversal during late orogenic folding, a fairly common phenomenon in alpine-type orogenic belts (for instance, Porada, 1979). In some other instances, the southward vergence is probably the result of superposition of late Cenozoic deformation, namely folding, faulting, and tilting by differential uplifting, on the Cretaceous structures. However, the cross sections across the Healy quadrangle strongly suggest that much of the southward vergence is the result of northward underthrusting, especially in the northern half of the quadrangle, during the early phase of the mid-Cretaceous accretionary orogeny.

The dominant structural style of the Cretaceous orogeny is thrust faulting. The most important of the thrust faults in the quadrangle, and of south-central Alaska as well, is the steeply to moderately southeast dipping Talkeetna thrust fault. This fault delineates, except for at least one thrust sliver in front of it (see cross section $A-A^{\prime}$ ), the northwestward extent of the largest and most significant allochthonous crustal fragment of south-central Alaska: the Talkeetna superterrane (Csejtey and others, 1982). The northwestward direction of tectonic transport along the Talkeetna thrust is indicated by a number of subsidiary, steeply southeastward dipping, imbricate thrust faults near the south edge of the quadrangle that are structurally above the Talkeetna thrust. These subsidiary faults consistently thrust older rocks from the south onto younger strata to the north (fig. 7 in Csejtey and others, 1982; cross section $B-B^{\prime}$ of this report)

The outlying thrust sliver of the Talkeetna thrust is composed of unit Kvs in the southwestern part of the quadrangle east of the Chulitna River valley (also see cross section $A-A^{\prime}$ ). The Triassic rocks were thrust onto Jurassic and Cretaceous flysch (unit KJf), and in tum the flyschlike rocks (KJfk) were thrust upon the Triassic rocks. Unit KJfk outlines a folded klippe approximately 60 by $35 \mathrm{~km}$ in surface dimensions.

Another example of Cretaceous thrusting is in the Ohio Creek area, called the Chulitna district, near the southwest corner of the quadrangle. In this area numerous thrusts, some of which have configurations that are poorly understood, superposed a number of disparate rock sequences ranging in age from Devonian to Cretaceous (map units Dsb, KDv, Kr, Klb, Jkrs, and KJa; fig. 5 in
Csejtey and others, 1982). Gravity measurements across these thrust slivers, along Ohio Creek, confirm that they are rootless thrust sheets (R.L. Morin, U.S. Geological Survey, oral commun., 1977).

Evidence that the Cretaceous thrusting not only juxtaposed disparate units, but also imbricated units that are parts of a continuous stratigraphic sequence, can be found in the east-central part of the quadrangle. At two localities within that general area, one near the headwaters of Dick Creek and another in an unnamed westerly side valley of the Gillam Glacier, unit Dy has been thrust upon unit $\mathrm{kcs}$. As previously discussed in the unit descriptions, unit Kcs unconformably overlies unit Dy. The extents and the displacements of these thrusts are not known because the one near Dick Creek is largely covered by the unconformably overlying Tertiary Cantwell Formation, and the one near the Gillam Glacier is only partially exposed next to a crosscutting Cenozoic high-angle reverse fault. Most probably there are more thrusts within unit Dy, but they cannot be detected in the field becauses of poor exposures and the lithologically monotonous nature of unit Dy.

North of the Hines Creek fault, most if not all the contacts between the various Precambrian(?) and Paleozoic units, as previously discussed in the unit descriptions, are believed to be thrust faults (Wahrhaftig, 1968). The thrusts involving units Dy and Kcs in the eastern part of the quadrangle lend further probability to this postulation. The concept of thrusting is also supported by the results of magnetotelluric measurements across the Hines Creek fault in the north-central part of the quadrangle, along the George Parks Highway (Dal Stanley, U.S. Geological Survey, unpub. data, 1985; Stanley, 1986). These measurements suggest that unit Pzp $\mathrm{p}$ north of the Hines Creek fault, that is, rocks of the Yukon-Tanana terrane (terrane nomenclature after Jones and Silberling, 1979), is underiain at depth by a thick section of Jurassic and Cretaceous flyschlike rocks (KJf). All these data and geologic considerations, which suggest thrusting, were taken into account when constructing the northern parts of cross sections $A-A^{\prime}$ and $B-B^{\prime}$, as were the correlations, proposed in this report, of units Dy and $\mathrm{kCs}$ with the Yukon-Tanana terrane. In order for the Jurassic and Cretaceous flyschlike rocks (KJf) to be tucked under unit $R_{z p} €_{p}$, units Dy and $\mathrm{k} c \mathrm{~s}$ had to be emplaced first. The thicknesses used for units KJf, Dy, and $\mathrm{K}$ cs are only estimates. The nature and the position of the contact between unit $\mathrm{KJf}$ and the underlying rocks, interpreted here to belong to the ancient North American Continent, is again not known, but for the most part it is assumed to be tectonic. On the basis of the perceived tectonic history of northwestward plate motions in the northem Pacific region since at least late Mesozoic time, we considered two mechanisms for the process of "undertucking": north- or northwestward overthrusting and northwestward underthrusting. We propose the mechanism of northwestward underthrusting because overthrusting would necessitate the unlikely scenario of all of the YukonTanana terrane of Alaska to be an allochtonous mass, rooted somewhere far south from its present exposure area. The overall geology of the Healy quadrangle suggests 
that this underthrusting near the south margin of the ancient North American Continent slightly preceded the accretion of the Talkeetna superterrane.

In addition to thrust faulting, the Cretaceous orogeny also produced some steeply dipping faults. The best example of these is the Hines Creek fault, which is interpreted in this report to be primarily a north-side-down dip-slip fault, possibly with significant right-lateral movement, within the Yukon-Tanana terrane.

The Cretaceous orogeny also caused widespread and intense folding that occurred not only concurrently with the thrusting, but both before and after it. Most of the preCenozoic rocks of the quadrangle are severely folded. The folds generally are tight or isoclinal and range in size from small secondary folds to megafolds with amplitudes of several kilometers. The larger folds commonly have a welldeveloped axial-plane slaty cleavage with fine-grained secondary sericite or biotite, and their limbs are frequently sheared or faulted out. The best examples of the megafolds are in the previously discussed areas to the east and west of the Chulitna River. The antiform in the Precambrian(?) and Paleozoic rocks of the Yukon-Tanana terrane north of the Hines Creek fault, also mentioned previously in the descriptions of map units Dmf, Dmb, $\mathrm{MDt}, P_{2} k_{\text {, and }} P_{z p} E_{p}$, has a variable amplitude of several thousands of meters (Wahrhaftig, 1970b, 1970c, 1970d).

The Maclaren metamorphic belt of Smith (1970, 1974, 1981), a Barrovian-type, late-tectonic metamorphic belt in the southeastern part of the quadrangle but north of the Talkeetna thrust fault, is associated with the Cretaceous orogeny. The approximate extent of the amphibolite-facies rocks and the approximate locations of the garnet and biotite isograds of this metamorphic belt are shown on map $\mathrm{C}$, sheet 2 of this report. Features of this early Late Cretaceous metamorphic belt cross the McKinley fault of the Denali fault system without any significant horizontal offsets (Csejtey and others, 1982), which suggests that the previously proposed large-scale horizontal displacements along the fault (Smith, 1974; Forbes and others, 1974; Reed and Lanphere, 1974; Turner and others, 1974; Hickman and others, 1977; Jones and others, 1982; Stout and Chase, 1980; Nokleberg and others, 1985) do not exist.

The age of the mid- to Late Cretaceous orogenic deformation, or at least its major phase, and that of the associated Maclaren metamorphic belt, is rather well bracketed by stratigraphic evidence. The youngest rocks ( $\mathrm{KJf}, \mathrm{KJfk}, \mathrm{KJ} c \mathrm{~g}$, and $\mathrm{KJa}$ ) clearly predating the mid- to Late Cretaceous deformation are Early Cretaceous (Valanginian) in age. One of the strongly deformed Jurassic and Cretaceous flysch units (KJfl) yieided early Late Cretaceous (Cenomanian) fossils. However, Late and latest Early Cretaceous granitic rocks (Kgr) in the eastern part of the quadrangle appear to be emplaced at a late stage of this orogenic deformation. Thus, the Cenomanian rocks may be coeval with the main phase of the orogenic deformation, perhaps having been deposited in a tectonically quiet "pocket". One upper age bracket is provided by the Paleocene Cantwell Formation, which everywhere rests unconformably on intensely and penetratively deformed and regionally metamorphosed
Cretaceous and older rocks. The Cantwell has not undergone regional metamorphism, and it is only moderately and nonpenetratively deformed. Another age bracket is provided by the unmetamorphosed and only moderately deformed early Tertiary volcanic and plutonic rocks (Tvv, Tgr), which rest unconformably on or intrude all older intensely deformed and (or) metamorphosed rocks.

The late Tertiary and Quaternary nonpenetrative deformation produced dominantly high to moderate angle reverse faults, generally open folds, differential uplift, and some normal faults. The present topography of southcentral Alaska, including that of the Healy quadrangle, is the result of this deformation (for instance, Wahrhaftig, 1970a),

Some of the more prominent of these late Cenozoic structures are in the east-central part of the Healy quadrangle, where at least two high-angle reverse faults, up on the south side, roughly delineate the northern extent of the high mountains around and including Mount Deborah. Although these faults, located just south of the Hines Creek fault, do not show any detectable evidence of recent movement, they undoubtedly control the present topography. Displacements along these south-dipping high-angle fauits appear to increase eastward, but in a westerly direction they die out in the vicinity of Yanert Fork. Near the east edge of the quadrangle, the two faults appear to merge with the Cretaceous Hines Creek fault (see also geologic map). In the southwestern part of the Mount Hayes quadrangle, which adjoins the Healy quadrangle to the east, a number of moderately northward dipping thrust faults roughly delineate the south edge of a high mountainous area to the north (Nokleberg and others, 1982). These high mountains are the eastward extension of the mountains around Mount Deborah in the eastern part of the Healy quadrangle. The two sets of faults delineating the northern and southern limits of the high mountains in the eastern Healy and western Mount Hayes quadrangles may constitute a structural phenomenon from the Italian Appenines described by Migliorini (1948) as a "composite wedge" (see also discussion of this structural feature in De Sitter, 1964, p. 211-212). In cross section, a composite wedge comprises a number of centrally upthrust wedge-shaped blocks, bounded by upwarddiverging faults. Another possible explanation is that the above faults in the eastern Healy and western Mount Hayes quadrangles comprise yet another structural phenomenon called "positive flower structure" (for example, Harding, 1985), which develops in conjunction with transpressional wrench faults, that is, steeply dipping lateral faults with both lateral and convergent slip components. In central Alaska, including the Healy quadrangle, the McKinley fault of the Denali fault system (to be discussed subsequently) appears to be such a fault, but with only relatively minor Cenozoic horizontal displacements.

Other important late Cenozoic structures are the highangle reverse faults flanking the McKinley fault in the western part of the Healy quadrangle. These faults outline topographically and structurally high areas and have brought to the surface units DOs, Kbd, KPs, and $\mathrm{Kmn}$ 
(see cross section $A-A^{\prime}$ ). The first three of these units are interpreted in this report to be part of the ancient North American Continent and to underlie the Jurassic and Cretaceous flyschlike rocks (primarily units $\mathrm{KJf}, \mathrm{KJfl}$, and $\mathrm{KJfk}$ ). The high-angle reverse faults may well be part of a "positive flower structure" along the transpressional McKinley fault.

The age of the late Cenozoic deformation is based on stratigraphic evidence. All the rocks older than the Nenana Gravel are intensely affected by this deformation. To a lesser degree, the Miocene and Pliocene Nenana Gravel $(T n)$ is also affected. The lithologic characteristics of all the pre-Nenana Tertiary rocks, especially the coal-bearing rocks ( $T \mathrm{cb})$, indicate that the area of the present central Alaska Range during that time was a depositional lowland (Wahrhaftig, 1970a, 1975). Thus, the generally coarsegrained rocks of the Nenana Gravel signal the onset of the still ongoing late Cenozoic regional tectonic deformation and accompanying uplift of the central Alaska Range.

The McKinley fault of the Denali fault system, a prominent and scientifically controversial structural feature, transects the middle of the quadrangle in a roughly eastwest direction. Within the quadrangle, the McKinley fault always occurs in topographically low areas, appears to be vertical or nearly vertical, and in a right-lateral sense clearly offsets for a distance of a few meters several modern or late Holocene alluvial fans and lateral moraines.

In the past the Denali fault system, which has a northward-convex surface trace more than $1,200 \mathrm{~km}$ long across the entire width of the State of Alaska, has been described by several workers as a major strike-slip feature with perhaps as much as several hundred kilometers of Cenozoic right-lateral offset (for instance, Forbes and others, 1974; Nokleberg and others, 1985). The following geologic phenomena in the Healy quadrangle suggest that such large displacement magnitudes along the Denali fault system do not exist: (1) apparent continuity of amphibolitegrade rocks and garnet and biotite isograds across the McKinley fault in the eastern part of the quadrangle (Csejtey and others, 1982; map C, sheet 2 of this report); (2) the occurrence on both sides of the McKinley fault of the same Upper Triassic calcareous sedimentary rocks ( K cs) containing lithologically identical diabase sills and dikes; (3) the occurrence of the same Jurassic and Cretaceous flyschlike rocks (KJf) on both sides of the fault; (4) the occurrence of Cretaceous granitic plutons (Kgr), which are restricted to the eastern half of the quadrangle, opposite one another on each side of the fault; (5) the occurrence of early Tertiary volcanic rocks (TVV. Tcv, and Tvif) on both sides of the fault but only in the western twothirds of the quadrangle; (6) the occurrence south of the fault in the western part of the quadrangle of lower Tertiary sedimentary rocks that contain limestone pebbles (TfV)these rocks are lithologically identical to the Cantwell Formation north of the fault, and might possibly be correlative with the Cantwell Formation; (7) the occurrence of very similar melangelike rocks ( $\mathrm{Kms}$ and $\mathrm{Kmn}$ ), although in apparently different structural and (or) stratigraphic positions, on both sides of the McKinley fault; (8) lack of changes in the aeromagnetic values and anomaly patterns across both the Hines Creek and
McKinley faults, in contrast with the marked changes across the Talkeetna thrust fault (Decker and Karl, 1977; Csejtey and Griscom 1978; Bella Csejtey, unpub. data, 1985); (9) lack of changes in the Bouguer gravity magnitudes and anomaly patterns across the Hines Creek and McKinley faults, again in contrast with the considerable changes across the Talkeetna thrust fault (Barnes, 1977; Béla Csejtey, unpub. data, 1985); (10) the apparent continuation of a Late Cretaceous and (or) early Tertiary northeast-trending broad belt of tin anomalies, defined by stream-sediment sample analyses, across the McKiniey fault in the southwestern and central part of the quadrangle (T.D. Light and R.B. Tripp, U.S. Geological Survey, unpub. data, 1984; Light and others, 1987); and (11) the overall similarity of age and tectonic style of orogenic deformation of the pre-Cenozoic rocks on both sides of the McKinley fault.

Although none of the above phenomena by themselves are conclusive evidence, and some of them are admittedly not unequivocal, all of them together strongly suggest that Cenozoic horizontal displacements along the McKinley fault are minimal, probably not more than a few tens of kilometers at most.

As mentioned previously, a number of workers postulated large-scale horizontal displacements along the Denali fault system in Cenozoic time (references summarized in Lanphere, 1978; and in Csejtey and others. 1982). In evaluating these previously proposed displacements from a regional point of view, we noted that none of the earlier workers satisfactorily explained the problem of large-scale strike-slip motion along a fault that has a sharply curving surface trace. Many of these workers ignored the problem altogether. The curvature between the western and eastern parts of the Denali fault systern in Alaska is about $70^{\circ}$, and the radius is not uniform. Other points worth considering concerning the various proposals of large-scale Cenozoic dextral movement along the Denali fault system are as follows: (1) each proposal is based on the tenuous correlation of a single geologic feature across the fault, such as a possible tectonostratigraphic terrane boundary, a pluton, or a metamorphic belt; (2) the various previously proposed Cenozoic movement magnitudes differ greatly and in fact contradict one another; and (3) the proposed correlation of the Maclaren metamorphic belt with metamorphic and plutonic rocks in the Kluane LakeRuby Range area in the southwestern Yukon Territory of Canada (for instance, Nokleberg and others, 1985) is quite tenuous because the rocks in the Kluane Lake-Ruby Range area have not been mapped and studied in sufficient detail to use as a foundation for regional correlations.

\section{TECTONICS}

Because Csejtey and others (1982) give a comprehensive history of the tectonic evolution of southcentral Alaska, only a brief summary of the subject is given here. However, subsequent geologic investigations in the Healy quadrangle that resulted in minor modifications of the tectonic concept are discussed in detail in this report.

South-central Alaska, including the Healy quadrangle, is part of the accretionary continental margin of western 
North America, which consists of a number of allochthonous and geologically disparate crustal fragments called tectonostratigraphic terranes (for instance, Coney and others, 1980). In south-central Alaska these terranes, mostly of undetermined geographic origin, were accreted to the ancient North American Continent by northward or northwestward plate motions in late Mesozoic time (for instance, Csejtey and others, 1982; Jones and others, 1984). The actual number of terranes present and the mechanism, direction, and time of final emplacement of these terranes are imperfectly known and, thus, are still open to question and conjecture.

According to Csejtey and others (1982), much of the geology of south-central Alaska has resulted from the collision and subsequent obduction of the Talkeetna superterrane with and onto the margin of the ancient North American Continent, including the Yukon-Tanana and Nixon Fork terranes, in about mid-Cretaceous time (nomenclature of individual terranes is that of Jones and Silberling, 1979). The Talkeetna superterrane is comprised of the Wrangellia and Peninsular terranes, which as their stratigraphies indicate, were joined at least by Middle Jurassic time, before their emplacement in Alaska as a cohesive tectonic unit. According to Jones and others (1984), the Wrangellia and Peninsular terranes have been joined together and thus had a common geologic history only since about Middle Jurassic time. However, geologic mapping by Detterman and Reed (1980) and by Wilson and others (1985a) indicates that in the Alaska Peninsula the Lower Jurassic Talkeetna Formation of the Peninsular terrane depositionally overlies upper Paleozoic and Triassic volcanic and sedimentary rocks, which may be part of the Wrangellia terrane. If their correlation is valid, the Wrangellia and Peninsular terranes always shared a common geologic history and, thus, should not be considered separate terranes. In addition to the Wrangellia and Peninsular terranes of Jones and Silberling (1979), the Talkeetna superterrane probably included some other terranes before its accretion to ancient North America (for instance, Pavlis, 1982).

Csejtey and others (1982) postulate that the Talkeetna superterrane and possibly a few smaller geologically disparate continental fragments in front of it were emplaced in their present positions by a north- or northwestward-moving lithospheric plate. On the northeast this plate terminated against the ancient North American continent in a transform fault, but on the northwest it was subducted under the Continent. The leading edges of the approaching continental fragments were separated from the ancient North American Continent by an oceanic basin of dominantly flysch deposits. Upon reaching the trench, the Talkeetna superterrane and perhaps some other small continental fragments in front of it, because of their relatively lighter continental compositions, could not be subducted but were sheared off their "undercarriage" and were subsequently obducted onto the margin of the ancient North American Continent by continuing northward plate motions. During this process the intervening flysch basin collapsed. The concept of northwestward obduction, for a distance of perhaps as much as $200 \mathrm{~km}$, is supported by geophysical evidence and by the absence of exposed volcanic arc and trench assemblage-type rocks, which may have been masked by the overthrust Talkeetna superterrane. Cross sections, based on the results of recent geologic and geophysical investigations, across the Healy quadrangle and extending into the northern Talkeetna Mountains quadrangle suggest that the obduction of the Talkeetna superterrane was slightly preceded by deformation of the margin of the ancient North American Continent by north- or northwestward underthrusting. This shortening of the continental margin also involved the Jurassic and Cretaceous flyshlike rocks. Thus, the Talkeetna superterrane was obducted onto an aiready deformed continental margin. The structural features resulting from this underthrusting, collision, and subsequent obduction are complex, gigantic, and truly alpine in style and character.

Recent geologic investigations in the Healy quadrangle strongly suggest that the Yukon-Tanana terrane extends south of the Hines Creek fault as well as south of the McKinley fault of the Denali fault system (see also map $\mathrm{C}$, sheet 2 and the descriptions of units Dy and $\mathrm{kcs}$ ). These investigations lend credence to the previous hypothesis that the Jurassic and Cretaceous flyschlike rocks (KJf and $\mathrm{KJfl})$ are underlain by continental crustal rocks of the Yukon-Tanana and Nixon Fork terranes (Csejtey and others, 1982). This is in agreement with seismic investigations in southern Alaska by Davies and Berg (1973); which suggest that the exposure areas of the Jurassic and Cretaceous flyschlike rocks in the Healy quadrangle and adjacent regions are underlain by continental rocks to a depth of about 35 to $40 \mathrm{~km}$, the depth of the Mohorovicic discontinuity. According to the above hypothesis, neither the Hines Creek fault nor the McKinley fault of the Denali fault system are terrane boundary faults. This is also supported by the lack of changes in the Bouguer gravity and aeromagnetic patterns and values across both of these faults (Barnes, 1977; and Decker and Karl, 1977, respectively).

Geologic investigations also strongly suggest that the Nixon Fork terrane occurs in the Healy quadrangle (Mullen and Csejtey, 1986). Lithologic and paleontologic studies on the carbonate-rich rocks of unit DOs of the quadrangle, previously designated by Jones and Silberling (1979) to belong to the Dillinger terrane, have disclosed that these rocks have close lithologic, temporal, and spatial relations with the deep-water or "shale-out" facies of the Nixon Fork carbonate platform of Churkin and others (1980). These "shale-out" beds are found about $300 \mathrm{~km}$ southwest of the quadrangle. Dutro and Patton (1982) also considered the "shale-out" beds, at least in part, to be the southeastward deepening deep-water-facies equivalents of the Nixon Fork and Minchumina terranes. Blodgett and Gilbert (1983), Blodgett and others (1984), and Blodgett and Clough (1985) concluded that the Nixon Fork and Dillinger terranes were actually part of the same early Paleozoic continental margin with minor, if any, displacement with respect to the North American craton. If the above conclusions are valid, then the western area of the Yukon-Tanana terrane in Alaska, as shown by Jones and Silberling (1979) and by Jones and others (1981a), is flanked on the north, west, and south by carbonate-rich rocks of the Nixon Fork terrane. This also means that the 
late Mesozoic continental margin upon which the Talkeetna superterrane is interpreted to have been obducted, did include carbonate-rich rocks of the Nixon Fork terrane. Accordingly, the origin of the Paleozoic limestone blocks in (melange) units $\mathrm{Kms}$ and $\mathrm{Kmn}$ of the Healy quadrangle could be explained as thrust slivers stripped off the continental margin and then intermixed with the para-autochthonous Jurassic and Cretaceous flychlike rocks by the obduction of the Talkeetna superterrane and by the preceding underthrusting along the margin of the ancient North American Continent.

The obduction interpretation is further strengthened by the correlation of the Triassic basic volcanic and volcaniclastic rocks around the Honolulu Pass area with similar rock types that occur in small fault slivers along the Talkeetna thrust near the southeast corner of the quadrangle. All of these rocks are shown as unit Kvs on the geologic map. If our correlation is valid, then the Triassic volcanic and volcaniclastic rocks around Honolulu Pass must constitute a thnust sliver of the main Talkeetna thrust to the southeast, supporting the hypothesis that the Talkeetna thrust is indeed a southeastward-dipping feature, with regional tectonic transport toward the northwest. The south or southeastward dip of the Talkeetna thrust is further supported by the results of recent magnetotelluric investigations by Stanley (1986).

A problem of vital importance for the obduction theory is the correlation of the highly metamorphosed marblebearing metasedimentary rocks in the vicinity of Tsusena Creek (on some maps "River") near the south-central edge of the quadrangle. These rocks, shown as unit Kcs? on the geologic map, lithologically resemble metamorphosed rocks of unit kcs further to the northeast, but the correlation is rather tenuous because of lack of any fossils or any other diagnostic features. The marble-bearing metasedimentary rocks near Tsusena Creek occur between the Talkeetna thrust and the thrust sliver of unit Kvs (see geologic map and map $\mathrm{C}$, sheet 2 ), and if they really are part of unit Kcs, interpreted in this report to belong to the Yukon-Tanana terrane, then the obduction concept is a certainty. Unfortunately, efforts in the field to find some diagnostic features in the marble-bearing metasedimentary rocks have been unsuccessful.

The role of the Cenozoic deformation, including the Denali fault system, in the tectonic evolution of southcentral Alaska has been discussed previously in the "Structure" section, and it will not be repeated here.

In summary, geologic investigations in the Healy quadrangle, we believe, lend additional support to the previously expressed concept (Csejtey and others, 1982) that much of the geology of south-central Alaska is the result of the accretion and subsequent obduction of the Talkeetna superterrane to and onto the ancient North American Continent in about mid-Cretaceous time. Cenozoic deformation has slightly modified, but not substantially altered, this already accreted continental margin. Geologic investigations in the Healy quadrangle also indicate that the number of tectonostratigraphic terranes previously postulated to be present in southcentral Alaska (for instance, Jones and others, 1984) has been greatly exaggerated.

\section{REFERENCES CITED}

Albanese, Mary, 1980. The geology of three extrusive bodies in the central Alaska Range: Fairbanks, Alaska, University of Alaska, M.S. thesis, 104 p.

Anderson, R.L., 1973, The Denali fault (Hines Creek strand) in the Wood River area, central Alaska Range: Madison, Wisconsin, University of Wisconsin, M.S. thesis, 114 p., scale 1:63,360.

Barnes, D.F., 1977, Bouguer gravity map of Alaska: U.S. Geological Survey Geophysical Investigations Map GP913 , scale $1: 2,500,000$.

Barnes, F.F., 1967, Coal resources of Alaska: U.S. Geological Survey Bulletin 1242-B, p. B1-B36, scale $1: 2,500,000$.

Berg, H.C., Jones, D.L., and Richter, D.H., 1972, Gravina-Nutzotin belt-Tectonic significance of an upper Mesozoic sedimentary and volcanic sequence in southern and southeastern Alaska, in Geological Survey research 1972: U.S. Geological Survey Professional Paper 800-D, p. D1-D24.

Blodgett, R.B., 1977, A Givetian (late Middle Devonian) fauna from the Healy $B-4$ quadrangle, central Alaska Range, Alaska: Alaska Division of Geological and Geophysical Surveys Geologic Report 55, p. 1-2.

Blodgett, R.B., and Clough, J.G., 1985, The Nixon Fork terrane-Part of an in situ peninsular extension of the Paleozoic North American continent (abs.): Geological Society of America Abstracts with Programs, v. 17, no. 6. p. 342

Blodgett, R.B., and Gilbert, W.G., 1983, The Cheeneetnuk Limestone, a new Early(?) to Middle Devonian formation in the McGrath A- 4 and $A-5$ quadrangles, westcentral Alaska: Alaska Division of Geological and Geophysical Surveys Professional Report 85, 6 p., scale $1: 63,360$.

Blodgett, R.B., Potter, A.W., and Clough, J.G., 1984, Upper Ordovician-Lower Devonian biostratigraphy and paleoecology of the Jones Ridge-Squaw Mountain area, east-central Alaska (abs.): Geological Society of America Abstracts with Programs, v. 16, no. 5, p. 270.

Bouma, A.H., 1962, Sedimentology of some flysch deposits-A graphic approach to facies interpretation: Amsterdam, Elsevier, $168 \mathrm{p}$.

1964, Turbidites, in Bouma, A.H., and Brouwer, A, eds., Turbidites: Amsterdam, Elsevier, p. 247-256.

Brewer, W.M., 1982, Stratigraphy, structure, and metamorphism of the Mount Deborah area, central Alaska Range, Alaska: Madison, Wisconsin, University of Wisconsin, Ph.D. dissertation, 318 p., scale 1:63,360.

Brooks, A.H., and Prindle, L.M., 1911, The Mount McKinley region, Alaska: U.S. Geological Survey Professional Paper 70, 234 p., scale 1:625,000.

Buddington, A.F., 1959, Granite emplacement with special reference to North America: Geological Society of America Bulletin, v. 70 , no. 6 , p. $671-747$.

Bultman, T.R., 1972, The Denali fault (Hines Creek strand) near the Nenana River, Alaska: Madison, Wisconsin, University of Wisconsin, M.S. thesis, 161 p., scale 1:63,360.

Capps, S.R., 1912, The Bonnifield region, Alaska: U.S. Geological Survey Bulletin 501, 64 p. 
Capps, S.R., 1932, The eastem portion of Mount McKiniey National Park: U.S. Geological Survey Bulletin 836-D, p. 219-300, scale 1:250,000.

1940, Geology of the Alaska Railroad region: U.S. Geological Survey Bulletin 907, 201 p., scale 1:250,000.

Churkin, Michael, Jr., Carter, Claire, and Trexler, J.H., Jr., 1980, Collision-deformed Paleozoic continental margin of Alaska-Foundation for microplate accretion: Geological Society of America Bulletin, pt. 1, v. 91, no. 11, p. 648-654.

Clark, A.L., Clark, S.H.B., and Hawley, C.C., 1972, Significance of upper Paleozoic oceanic crust in the Upper Chulitna district, west-central Alaska Range, in Geological Survey research 1972: U.S. Geological Survey Professional Paper 800-C, p. C95-C101.

Coney, P.J., Jones, D.L., and Monger, J.W.H., 1980, Cordilleran suspect terranes: Nature, v. 288, p. 329-333.

Csejtey, Béla, Jr., Cox, D.P., Evarts, R.C., Striker, G.D., and Foster, H.L., 1982, The Cenozoic Denali fault systern and the Cretaceous accretionary development of southern Alaska: Journal of Geophysical Research, v. 87 , no. B5, p. 3,741-3,754.

Csejtey, Béla, Jr., and Griscom, Andrew, 1978, Preliminary aeromagnetic interpretive map of the Talkeetna Mountains quadrangle, Alaska: U.S. Geological Survey Open-File Report 78-558-C, 14 p., scale 1:250,000.

Csejtey, Béla, Jr., Neison, W.H., Jones, D.L., Silberling, N.J., Dean, R.M., Morris, M.S., Lanphere, M.A., Smith, J.G., and Silberman, M.L., 1978, Reconnaissance geologic map and geochronology, Talkeetna Mountains quadrangle, northern part of Anchorage quadrangle, and southwest corner of Healy quadrangie, Alaska: U.S. Geological Survey Open-File Report 78-558-A, 62 p., scale 1:250,000.

Csejtey, Béla, Jr., and St. Aubin, D.R., 1981, Evidence for northwestward thrusting of the Talkeetna superterrane, and its regional significance, in Albert, N.R.D., and Hudson, Travis, eds., The United States Geological Survey in Alaska: Accomplishments during 1979: U.S. Geological Survey Circular 823-B, p. B49-B51.

Csejtey, Belia, Jr., Yeend, W.E., and Goerz, D.J., III, 1984. Occurrence of the Cantwell(?) Formation south of the Denali fault system in the Healy quadrangle, southem Alaska, in Coonrad, W.L., and Elliott, R.L., eds., The United States Geological Survey in Alaska: Accomplishments during 1981: U.S. Geological Survey Circular 868 , p. $77-79$.

Dairymple, G.B., 1979, Critical tables for conversion of KAr ages from old to new constants: Geology, v. 7, no. 11 , p. $558-560$.

Davies, J.N., and Berg, Edward, 1973, Crustal morphology and plate tectonics in south-central Alaska: Seismological Society of America Bulletin, v. 63, no. 2, p. 673-677.

Decker, J.E., 1975, Geology of the Mount Galen area, Mount McKinley National Park, Alaska: Fairbanks, Alaska, University of Alaska, M.S. thesis, $77 \mathrm{p}$.

Decker, John, and Karl, S.M., 1977, Preliminary aeromagnetic map of the eastern part of southern Alaska: U.S. Geological Survey Open-File Map 77-169E, scale $1: 1,000,000$.
De Sitter, L.U., 1964, Structural geology, 2nd edition: New York, McGraw-Hill, 551 p.

Detterman, R.L., and Reed, B.L., 1980, Stratigraphy. structure, and economic geology of the lliamna quadrangle, Alaska: U.S. Geological Survey Bulletin 1368-B, p. B1-B86, scale 1:250,000.

Dunham, R.J., 1962, Classification of carbonate rocks according to depositional texture, in Ham, W.E., ed., Classification of carbonate rocks- A symposium: American Association of Petroleum Geologists Memoir 1, p. 108121.

Dutro, J.T., Jr., and Patton, W.W., Jr., 1982, New Paleozoic formations in the northern Kuskokwim Mountains, west-central Alaska, in Stratigraphic notes, 1980 1982: U.S. Geological Survey Bulletin 1529-H. p. $\mathrm{H} 13-\mathrm{H} 22$

Eldridge, G.H., 1900, A reconnaissance in the Susitna Basin and adjacent territory, Alaska, in 1898, in Explorations in Alaska in 1898: U.S. Geological Survey Annual Report 20, pt. 7, p. 1-29.

Epstein, A.G., Epstein, J.B., and Harris, L.D., 1977, Conodont color alteration-An index to organic metamorph. ism: U.S. Geological Survey Professional Paper 995. 27 p.

Forbes, R.B.. Smith, T.E., and Turner, D.L., 1974. Comparative petrology and structure of the Maclaren, Ruby Range, and Coast Range belts: Implications for offset along the Denali fault system (abs.): Geological Society of America Abstracts with Programs, v. 6, no. 3, p. 177.

Foster, H.L., and Keith, T.E.C.. 1974. Ultramafic rocks of the Eagle quadrangle, east-central Alaska: U.S. Geological Survey Journal of Research, v. 2, no. 6. p. 657-669.

Foster, H.L., Laird, Jo, Keith, T.E.C., Cushing, G.W., and Menzie, W.D., 1983, Preliminary geologic map of the Circle quadrangle, Alaska: U.S. Geological Survey Open-File Report 83-170-A, 30 p., scaie 1:250,000

Foster, H.L., Weber, F.R., Forbes, R.B., and Brabb, E.E. 1973, Regional geology of Yukon-Tanana upland. Alaska, in Pitcher, M.G., ed., Arctic geology: American Association of Petroleum Geologists Memoir 19, p. 388 395.

Gilbert, W.G., 1977, General geology and geochemistry of Healy D-1 and southern Fairbanks A-1 quadrangles and vicinity, Alaska: Alaska Division of Geological and Geophysical Surveys Open-File Report AOF-105, 12 p., scale $1: 63,360$.

Gilbert, W.G., and Bundtzen, T.K., 1976, General geology and geochemistry of Healy D-5 and D-6 quadrangles, Alaska: Alaska Division of Geological and Geophysical Surveys Open-File Report AOF-101, 6 p., scale $1: 63,360$.

1979. Mid-Paleozoic tectonics, volcanism, and mineralization in north-central Alaska Range, in Sisson, Alexander, ed. The relationship of plate tectonics to Alaskan geology and resources: Alaska Geological Society, Proceedings of the sixth Alaska Geological Society Symposium, 1977, p. F1-F22.

Gilbert, W.G., Ferrell, V.M., and Turner, D.L., 1976, The Teklanika Formation-A new Paleocene volcanic formation in the central Alaska Range: Alaska Division of Geological and Geophysical Surveys Geologic Report 47, 16, p., scale 1:63,360. 
Gilbert, W.G., Nye, C.J., and Sherwood, K.W., 1984, Stratigraphy, petrology, and geochemistry of Upper Triassic rocks from the Pingston and McKinley terranes: Alaska Division of Geological and Geophysical Surveys Report of Investigations 84 30, 14 p.

Gilbert, W.G., and Redman, Earl, 1975, Geologic map and structure sections of Healy $\mathrm{C}-6$ quadrangle, Alaska: Alaska Division of Geological and Geophysical Surveys Open-File Report AOF-80, 2 p., scale 1:40,000. 1977, Metamorphic rocks of Toklat-Teklanika Rivers area, Alaska: Alaska Division of Geological and Geophysical Surveys Geologic Report 50, 13 p. scale $1: 63,360$.

Harding, T.P., 1985, Seismic characteristics and identification of negative flower structures, positive flower structures, and positive structural inversion: The American Association of Petroleurn Geologists Bulletin, v. 69, no. 4 , p. $582-600$

Hawley, C.C., and Clark, A.L., 1973, Geology and mineral deposits of the Chulitna-Yentna mineral belt, Alaska: U.S. Geological Survey Professional Paper 758A, 10 p., scales 1:250,000 and 1:500,000.

1974, Geology and mineral deposits of the Upper Chulitna district, Alaska: U.S. Geological Survey Professional Paper 758-B, 47 p., scales 1:48,000 $1: 24,000$, and 1:12,000.

Hickman, R.G., 1971, The Denali fault near Cantwell, Alaska: Madison, Wisconsin, University of Wisconsin, M.S. thesis, 76 p., scale 1:63,360.

1974, Structural geology and stratigraphy along a segment of the Denali fault system, central Alaska Range, Alaska: Madison, Wisconsin, University of Wisconsin, Ph.D. dissertation, 276 p., scale 1:63,360.

Hickman, R.G., and Craddock, Campbell, 1976, Geologic map of central Healy quadrangle, Alaska: Alaska Division of Geological and Geophysical Surveys Open-File Report AOF-95, scale 1:63,360.

Hickman, R.G., Craddock, Campbell, and Sherwood, K.W., 1977, Structural geology of the Nenana River seg. ment of the Denali fault system, central Alaska Range: Geological Society of America Bulletin, v. 88, no. 9, p. 1217-1230.

Hillhouse, J.W., 1977, Paleomagnetism of the Triassic Nikolai Greenstone, McCarthy quadrangle, Alaska: Canadian Joumal of Earth Sciences, v. 14, no. 11, p. 2578-2592.

Hillhouse, J.W., and Gromme, C.S., 1982, Limits of northward drift of the Paleocene Cantwell Formation, central Alaska: Geology, v. 10 , no. 10, p. 552-556.

1984, Northward displacement and accretion of Wrangellia: Journal of Geophysical Research, v. 89, no. B6, p. $4461-4477$.

Hillhouse, J.W., Grommé, C.S., and Csejtey, Béla, Jr., 1984, Paleomagnetism of early Tertiary volcanic rocks in the northern Talkeetna Mountains, in Bartsch-Winkler, Susan, and Reed, K.M., eds., the United States Geological Survey in Alaska: Accomplishments during 1982: U.S. Geological Survey Circular 939, p. 50-52.

1985, Tectonic implications of paleomagnetic poles from lower Tertiary volcanic rocks, south-central Alaska: Journal of Geophysical Research, v. 90, no. B14, p. 12,523-12,535.
Hopkins, D.M., 1951, Lignite deposits near Broad Pass Station, Alaska, in Barnes, F.F., ed, Coal investigations in south-central Alaska, 1944-46: U.S. Geological Survey Bulletin 963-E. p. 187-191.

IUGS (International Union of Geological Sciences), 1973, Plutonic rocks; classification and nomenclature recommended by the IUGS Subcommission on the Systematics of Igneous Rocks: Geotimes, v. 18 , no. 10 , p. 2630.

Jones, D.L., and Silberling, N.J., 1979, Mesozoic stratigraphy-The key to tectonic analysis of southern and central Alaska: U.S. Geological Survey Open-File Report 79-1200, $37 \mathrm{p}$.

Jones, D.L., Silberling N.J., Berg, H.C., and Plafker, George, 1981a, Map showing tectonostratigraphic terranes of Alaska, columnar sections, and summary description of terranes: U.S. Geological Survey Open-File Report 81-792, 21 p., scale 1:2,500,000.

Jones, D.L., Silberling, N.J., Gilbert, W.G., and Coney, P.J., 1983, Tectonostratigraphic map and interpretive bedrock geologic map of the Mount McKinley region, Alaska: U.S. Geological Survey Open-File Report 8311 , scale $1: 250,000$.

Jones, D.L., Silberling N.J., Coney, P.J., and Plafker, George, 1984, Lithotectonic terrane map of Alaska (west of the 141st meridian), in Silberling, N.J., and Jones, D.L., eds., Lithotectonic terrane maps of the North American Cordillera: U.S. Geological Survey Open-File Report 84-523, p. A1-A12, scale 1:2,500,000.

Jones, D.L., Silberling, N.J., Csejtey, Béla, Jr., Nelson, W.H., and Blome, C.D.. 1980, Age and structural significance of ophiolite and adjoining rocks in the upper Chulitna district, south-central Alaska: U.S. Geological Survey Professional Paper 1121-A, P. A1-A21, scale 1:63,360.

Jones, D.L., Silberling, N.J., Gilbert, W.G., and Coney, P.J., 1982, Character, distribution, and tectonic significance of accretionary terranes in the central Alaska Range: Journal of Geophysical Research, v. 87, no. B5, p. $3709-3717$.

Jones, D.L., Silberling, N.J., and Hillhouse, John, 1977, Wrangellia-A displaced terrane in northwestern North America: Canadian Journal of Earth Sciences, v. 14, no. 11, p. 2565-2577.

Jones, D.L., Silberling, N.J., Wardlaw, Bruce, and Richter, D.H., 1981b, Revised ages of Paleozoic and Mesozoic rocks in the Talkeetna quadrangle, south-central Alaska, in Albert, N.R.D., and Hudson, Travis, eds., the United States Geological Survey in Alaska: Accomplishments during 1979: U.S. Geological Survey Circular 823-B, p. B46-B49.

Lanphere, M.A., 1978, Displacement history of the Denali fault system, Alaska and Canada: Canadian Journal of Earth Sciences, v. 15 , no. 5, p. 817-822.

Light, T.D., Tripp, R.B., and King, H.D., 1987, Strearnsediment geochemistry of two mineral provinces in the Healy quadrangle. Alaska, in Elliott, I.L., and Smee, B.W., eds., GEOEXPO/86, exploration in the North American Cordillera: Rexdale, Ontario, Canada, Association of Exploration Geochemists, Symposium sponsored by the Association of Exploration Geochemists 
and the Cordilleran Section of the Geological Association of Canada, Vancouver, B.C., Canada, May 12-14, 1986, Proceedings, p. 126-131.

MacKevett, E.M., Jr., 1976, Geologic map of the McCarthy quadrangle, Alaska: U.S. Geological Survey Miscellaneous Field Studies Map MF-773-A, scale 1:250,000.

1978, Geologic map of the McCarthy quadrangle, Alaska: U.S. Geological Survey Miscellaneous Investigations Series Map I-1032, scale 1:250,000.

Migliorini, C.I., 1948, I cunei composti nell orogenesi (Composite wedges in orogenesis): Bollettino della Societa Geologica Italiana, v. 67, p. 29-142.

Moffit, F.H., 1915, The Broad Pass region, Alaska, with sections on Quaternary deposits, igneous rocks, and glaciation by J.E. Pogue: U.S. Geological Survey Bulletin 608,80 p., scale $1: 250,000$.

Moxham, R.M., Eckhart, R.A., and Cobb, E.H., 1959 , Geology and cement raw materials of the Windy Creek area, Alaska: U.S. Geological Survey Bulletin 1039-D, p. 67-100.

Mullen, M.W., and Csejtey, Béla, Jr., 1986, Recognition of a Nixon Fork terrane equivalent in the Healy quadrangle, in Bartsch-Winkler, Susan, and Reed, K.M., eds., Geologic studies in Alaska by the U.S. Geological Survey during 1985: U.S. Geological Survey Circular 978. p. $55-60$.

Nichols, K.M., and Silberling, N.J., 1979, Early Triassic (Smithian) ammonites of paleoequatorial affinity from the Chulitna terrane, south-central Alaska: U.S. Geological Survey Professional Paper 1121-B. p. B1-B5.

Nokleberg, W.J., Albert, N.R.D., Bond, G.C., Herzon, P.L., Miyoaka, R.T., Nelson, W.H., Richter, D.H., Smith, T.E., Stout, J.H., Yeend, W.E., and Zehner, R.E., 1982, Geologic map of the southern part of Mount Hayes quadrangle, Alaska: U.S. Geological Survey Open-File Report 82-52, 26 p., scale 1:250,000.

Nokleberg, W.J., Jones, D.L., and Silberling, N.J., 1985, Origin and tectonic evolution of the Maclaren and Wrangellia terranes, eastern Alaska Range, Alaska: Geological Society of America Bulletin, v. 96, no. 10, p. 1251-1270.

Parks, Bruce, 1983, Trace metals in surface water and stream sediments of Healy and Lignite Creek basins, Alaska: U.S. Geological Survey Water-Resources Investigations Report 83-4173, $26 \mathrm{p}$.

Patton, W.W., Jr., 1978, Juxtaposed continental and oceanic-island arc terranes in the Medfra quadrangle, west-central Alaska, in Johnson, K.M., ed., The United States Geological Survey in Alaska: Accomplishments during 1977: U.S. Geological Survey Circular 772-B, p. B38-B39.

Pavlis, T.L., 1982, Origin and age of the Border Ranges fault of southern Alaska and its bearing on the late Mesozoic tectonic evolution of Alaska: Tectonics, v. 1 , no. 4 , p. $343-368$

Péwé, T.L., Wahrhaftig, Clyde, and Weber, Florence, 1966, Geologic map of the Fairbanks quadrangie, Alaska: U.S. Geological Survey Miscellaneous Geologic Investigations Map I-455, scale 1:250,000.

Porada, Hubertus, 1979, The Damara-Ribeira orogen of the Pan-African-Brasiliano cycle in Namibia (southwest
Africa) and Brazil as interpreted in terms of continental collision: Tectonophysics, v. 57, p. 237-265.

Rautman, C.A., 1974, The Denali fault system in the Dick Creek-Wells Creek area, central Alaska Range, Alaska: Madison, Wisconsin, University of Wisconsin, M.S. thesis, 141 p., scale 1:63,360.

Reed, J.C., Jr., 1961, Geology of the Mount McKiniey quadrangle, Alaska: U.S. Geological Survey Bulletin 1108-A, 36 p., scale 1:250,000.

Reed, B.L., and Lanphere, M.A., 1974, Offset plutons and history of movement along the McKinley segment of the Denali fault system, Alaska: Geological Society of America Bulletin, v. 85 , no. 12 , p. 1883-1892.

Reed, B.L., and Nelson, S.W., 1980, Geologic map of the Talkeetna quadrangle, Alaska: U.S. Geological Survey Miscellaneous Investigations Series Map 1-1174, scale 1:250,000.

Richter, D.H., 1976, Geologic map of the Nabesna quadrangle, Alaska: U.S. Geological Survey Miscellaneous Investigations Series Map 1-932, scale 1:250,000.

Richter, D.H., and Dutro, J.T., Jr., 1975, Revision of the type Mankomen Formation (Pennsylvanian and Permian), Eagle Creek area, eastern Alaska Range, Alaska: U.S. Geological Survey Bulletin 1395-B, p. B1-B25.

Richter, D.H., and Jones, D.L., 1973, Structure and stratigraphy of eastern Alaska Range, Alaska, in Pitcher, M.G., ed., Arctic geology: American Association of Petroleum Geologists Memoir 19, p. 408-420.

Sanders, R.B., 1975, Coal resources of Alaska: Fairbanks, University of Alaska, School of Mineral Industry MIRL Report 37, p. 21-32.

Seraphim, R.H., 1975, Denali-a nonmetamorphosed stratiform sulfide deposit: Economic Geology, v. 70, no. 5, p. 949-959.

Sherwood, K.W., 1973, Geologic structure along the Hines Creek fault west of the Wood River, north-central Alaska Range: Madison, Wisconsin, University of Wisconsin, M.S. thesis, 131 p., scale $1: 63,360$.

1979, Stratigraphy, metarnorphic geology, and structural geology of the central Alaska Range, Alaska: Madison, Wisconsin, University of Wisconsin, Ph.D. dissertation, 692 p., scale 1:63,360.

Sherwood, K.W., and Craddock, Campbell, 1979, General geology of the central Alaska Range between the Nenana River and Mount Deborah: Alaska Division of Geological and Geophysical Surveys Open-File Report AOF-116, map scale $1: 63,360$.

Silberling, N.J., Richter, D.H., and Jones, D.L., 1981a, Recognition of the Wrangellia terrane in the Clearwater Mountains and vicinity, south-central Alaska in Albert, N.R.D., and Hudson, Travis, eds., The United States Geological Survey in Alaska: Accomplishments during 1979: U.S. Geological Survey Circular 823-B, p. B51B55.

Silberling, N.J., Richter, D.H., Jones, D.L., and Coney, P.J., 1981b, Geologic map of the bedrock part of the Healy A-1 quadrangle south of the Talkeetna-Broxon Gulch fault system, Clearwater Mountains, Alaska: U.S. Geological Survey Open-File Report 81-1288, scale $1: 63,360$. 
Smith, T.E. 1970, Inverted metamorphic zonation in the northern Cleanwater Mountains, Alaska (abs.), in Geological Survey Research 1970: U.S. Geological Survey Professional Paper 700-A, p. A47-A48

1974, Regional geology of the Susitna-Maclaren River area: Alaska Division of Geological and Geophysical Surveys Annual Report 1973, p. 3-6.

1981, Geology of the Cleanwater Mountains, south-central Alaska: Alaska Division of Geological and Geophysical Surveys Geologic Report 60, 72 p., scale $1: 63,360$.

Smith, T.E., Albanese, M.D., and Kline, G.L., 1984, Geologic map of the Healy A-2 quadrangle, Alaska: Alaska Division of Geological and Geophysical Surveys, Report of Investigations 84-14, scale 1:63,360.

Smith, T.E., and Lanphere, M.A., 1971, Age of the sedimentation, plutonism and regional metamorphism in the Clearwater Mountains region, central Alaska: Isochron/West, no. 2, p. 17-20.

Smith, T.E., and Turner, D.L., 1973, Geochronology of the Maclaren metamorphic belt, south-central Alaska-a progress report: Isochron/West, no. 7, p. 21-25.

Spurr, J.E., 1898, Geology of the Yukon gold district, Alaska, in Geology of the Yukon gold district, Alaska, with an introductory chapter on the history and condition of the district to 1897 by H.B. Goodrich: U.S. Geological Survey Annual Report 18, part III, p. 87392.

Stanley, W.D., 1986, Magnetotelluric study of a compressed flysch system in the Healy and adjacent quadrangles, in Bartsch-Winkler, Susan, and Reed, K.M., eds., Geologic studies in Alaska by the U.S. Geological Survey during 1985: U.S. Geological Survey Circular 978 , p. $78-81$.

Steiger, R.H., and Jager, E., 1977, Subcommission on geochronology: Convention on the use of decay constants in geo- and cosmochronology: Earth and Planetary Science Letters, v. 36, p. 359-362.

Stone, D.B., 1982, Triassic paleomagnetic data and paleolatitudes for Wrangellia, Alaska: Alaska Division of Geological and Geophysical Surveys Geologic Report 73 , p. $55-62$

Stout, J.H., 1976, Geology of the Eureka Creek area, eastcentral Alaska Range: Alaska Division of Geological and Geophysical Surveys Geologic Report 46, 32 p., scale $1: 63,360$.

Stout, J.H., and Chase, C.G., 1980, Plate kinematics of the Denali fault system: Canadian Journal of Earth Sciences, v. 17 , no. 11 , p. 1527-1537.

Swainbank, R.C., Smith, T.E., and Turner, D.L., 1977. Geology and $\mathrm{K}-\mathrm{Ar}$ age of mineralized intrusive rocks from the Chulitna mining district, central Alaska: Alaska Division of Geological and Geophysical Surveys Geologic Report 55, p. 23-28.

Turner, D.L., and Smith, T.E., 1974, Geochronology and generalized geology of the central Alaska Range, Clearwater Mountains and northem Talkeetna Mountains: Alaska Division of Geological and Geophysical Surveys Open-File Report 72, 11 p., scale 1:250,000.

Turner, D.L., Smith, T.E., and Forbes, R.B., 1974, Geochronology of offset along the Denali fault system in
Alaska (abs.): Geological Society of America Abstracts with Programs, v. 6, no. 3, p. 268-269.

Turner, F.J., 1968, Metamorphic petrology, mineralogical and field aspects: New York. McGraw-Hill, 403 p.

Umhoefer, P.J., 1984, Structure and stratigraphy of an Upper Triassic unit, Healy-A detailed study of part of the Pingston terrane in the central Alaska Range: Alaska Geological Society Journal, v. 4, p. 12-34.

Wahrhaftig, Clyde, 1944, Coal deposits of the Costello Creek basin, Alaska: U.S. Geological Survey open-file report, 7 p. scale 1:2,400.

1951, Geology and coal deposits of the western part of the Nenana coal field, Alaska, in Barnes, F.F., Coal investigations in south-central Alaska, 1944-46: U.S. Geological Survey Bulletin 963-E, p. 169-186.

1958, Quaternary geology of the Nenana River valley and adjacent parts of the Alaska Range: U.S Geological Survey Professional Paper 293-A, 68 p. 1968, Schists of the central Alaska Range: U.S. Geological Survey Bulletin 1254-E. p. E1-E22

1970a, Late Cenozoic orogeny in the Alaska Range (abs.): Geological Society of America Abstracts with Programs, v. 2, no. 7, p. 713-714.

$1970 \mathrm{~b}$, Geologic map of the Healy D-2 quadrangle, Alaska: U.S. Geological Survey Geologic Quadrangle Map GQ-804, scale 1:63,360.

1970c. Geologic map of the Healy D.3 quadrangle, Alaska: U.S. Geological Survey Geologic Quadrangle Map GQ-805, scale 1:63,360.

$1970 d$, Geologic map of the Healy D.4 quadrangle, Alaska: U.S. Geological Survey Geologic Quadrangle Map GQ-806. scale 1:63,360.

$1970 e$, Geologic map of the Healy D-5 quadrangle, Alaska: U.S. Geological Survey Geologic Quadrangle Map GQ-807, scale 1:63,360.

1975, Late Cenozoic orogeny in the Alaska Range (abs.), in Forbes, R.B., ed., Contributions to the geology of the Bering Sea Basin and adjacent regions: Geological Society of America Special Paper 151, p. 189-190.

Wahrhaftig, Clyde, and Black, R.F., 1958, Engineering geology along part of the Alaska Railroad: U.S. Geological Survey Professional Paper 293-B, p. 69-118

Wahrhaftig, Clyde, Hickcox, C.A., and Freedman, Jacob, 1951, Coal deposits on Healy and Lignite Creeks, Nenana coal field, Alaska, with a section on clay deposits on Healy Creek by E.H. Cobb, in Barnes, F.F., ed., Coal investigations in south-central Alaska, 1944-46: U.S. Geological Survey Bulletin 963-E, p. 141-165.

Wahrhaftig, Clyde, Turner, D.L., Weber, F.R., and Smith. T.E., 1975, Nature and timing of movement on Hines Creek strand of Denali fault system, Alaska: Geology. v. 3 , no. 8 , p. $463-466$.

Wahrhaftig, Clyde, Wolfe, J.A., Leopold, E.B., and Lanphere, M.A., 1969, The coal-bearing group in the Nenana coal field, Alaska: U.S. Geological Survey Bulletin 1274-D, p. D1-D30.

Walker, R.G., and Mutti, Emiliano, Turbidite facies associations, in Middleton, G.V., and Bouma, A.H., eds., Turbidites and deep-water sedimentation: Society of 
Economic Paleontologists and mineralogists, Pacific Section, Short course notes, p. 119-158.

Wardlaw, B.R., 1982, Smithian and Spathian (Early Triassic) conodont faunas from the Chulitna terrane, southcentral Alaska, in Coonrad, W.L., ed., The United States Geological Survey in Alaska: Accomplishments during 1980: U.S. Geological Survey Circular 844, p. 106-107.

Wegner, W.W., 1972, The Denali fault (Hines Creek strand) in the northeastern Mount McKinley National Park, Alaska: Madison, Wisconsin, University of Wisconsin, M.S. thesis, 74 p., scale 1:63,360.

Wilson, F.H., Detterman, R.L., and Case, J.E., 1985a, The Alaska Peninsula terrane; a definition: U.S. Geological
Survey Open-File Report 85-450, 17 p.

Wilson, F.H., Smith, J.G., and Shew, Nora, 1985b, Review of radiometric data from the Yukon crystalline terrane, Alaska and Yukon Territory: Canadian Journal of Earth Sciences, v. 22, no. 4, p. 525-537.

Wolfe, J.A., and Tanai, Toshimasa, 1980, The Miocene Seldovia Point fiora from the Kenai Group, Alaska: U.S. Geological Survey Professional Paper 1105, $52 \mathrm{p}$.

Wolfe, J.A., and Wahrhaftig, Clyde, 1970, The Cantwell Formation of the central Alaska Range, in Cohee, G.V., Bates, R.G., and Wright, W.B., eds., Changes in stratigraphic nomenclature by the U.S. Geological Survey, 1968: U.S. Geological Survey Bulletin 1294-A, p. A41A46. 
Table 1. Selected potassium-argon age determinations from the Healy quadrangie, Alaska

[All available potassium-argon age deterninations for the Healy quadrangle were considered in compiling this table. Only those deemed geologically or analytically reliable or significant have been included. Age determinations considered suspect or unreliable by original authors are omitted, as are those where age of intrusive rock appears to be older than the wellestablished age of the country rock. All omitted age determinations can be found in Wegner (1972), Hickman (1974), Hickman and Craddock (1976), Sherwood and Craddock (1979), and Aibanese (1980). Map number locations are shown on sheet 1. Data not available,-1

\begin{tabular}{|c|c|c|c|c|c|c|c|c|c|c|c|c|}
\hline \multirow{2}{*}{$\begin{array}{l}\text { Map } \\
\text { No. }\end{array}$} & \multirow{2}{*}{$\begin{array}{l}\text { Map } \\
\text { unit }\end{array}$} & \multicolumn{2}{|c|}{ Location } & \multirow{2}{*}{ Field No. } & \multirow{2}{*}{$\begin{array}{l}\text { Rock } \\
\text { type }\end{array}$} & \multirow{2}{*}{$\begin{array}{l}\text { Mineral } \\
\text { dated }\end{array}$} & \multirow{2}{*}{$\begin{array}{c}\mathrm{K}_{2} \mathrm{O} \\
\text { (weight } \\
\text { percent) }\end{array}$} & \multirow{2}{*}{$\begin{array}{l}{ }^{40} \mathrm{Ar}_{\text {rrd }} \\
\text { moles } \\
\text { gram }\end{array} 10^{-10}$} & \multirow[t]{2}{*}{$\frac{{ }^{40} \mathrm{Ar}_{\text {mad }}}{{ }^{40} \mathrm{Ar}_{\text {tow }}}$} & \multirow{2}{*}{$\begin{array}{l}\text { Previously } \\
\text { published age } \\
\text { (millions of } \\
\text { years) }\end{array}$} & \multirow{2}{*}{$\begin{array}{c}\text { Age calkulated } \\
\text { using } \\
\text { constants of } \\
\text { Steiger and } \\
\text { Jager, } 1977 \\
\text { (millions of } \\
\text { years) }\end{array}$} & \multirow[b]{2}{*}{ References } \\
\hline & & Lat (N.) & Long $\quad$ (W. & & & & & & & & & \\
\hline 1 & Thd & $63^{\circ} 58^{\prime} 36^{\prime}$ & $148^{\circ} 42^{\circ} 06^{\prime \prime}$ & 47 Awg- 142 & Dacite & Homblende & 0.866 & - & 0.096 & $2.72 \pm 0.25$ & ${ }^{3} 2.79 \pm 0.25$ & $\begin{array}{l}\text { M.A. Lanphere } \\
\text { in Wahrhaftig. } \\
1970 \text { d, Wilson } \\
\text { and others, } \\
1985 \mathrm{~b} \text {. }\end{array}$ \\
\hline 2 & Tvif & $63^{\circ} 45^{\circ} 05^{\prime \prime}$ & $148^{\circ} 47^{\prime} 24^{\prime \prime}$ & MR78-50 & Rhyolite & Whole rock & $3.277(4)$ & - & 0.846 & $35.2 \pm 1.0$ & ${ }^{3} 35.2 \pm 1.0$ & $\begin{array}{l}\text { Albanese, } 1980 \text {; } \\
\text { Wilson and } \\
\text { others, } 1985 \mathrm{~b} \text {. }\end{array}$ \\
\hline 3 & Tvif & $63^{\circ} 47^{\prime} 36^{\prime \prime}$ & $148^{\circ} 49^{\prime} 42^{\prime}$ & MR78-2 & Rhyolite & Whole rock & $4.425\{4\}$ & - & 0.964 & $34.2 \pm 1.0$ & ${ }^{3} 34.2 \pm 1.0$ & Do. \\
\hline 4 & Tvif & $63^{\circ} 47^{\prime} 24^{\prime \prime}$ & $148^{\circ} 49^{\prime} 36^{\prime \prime}$ & MR78-39 & Rhyolite & Whole rock & $4.344(4)$ & - & 0.019 & $32.5 \pm 1.0$ & ${ }^{3} 32.5 \pm 1.0$ & Da. \\
\hline 5 & Tvif & $63^{\circ} 46^{\prime} 48^{\prime \prime}$ & $148^{\circ} 48^{\prime} 18^{\prime \prime}$ & MR78-58 & Rhyolite & Whole rock & $4.729(4)$ & - & 0.891 & $32.8 \pm 1.0$ & ${ }^{3} 32.8 \pm 1.0$ & Do. \\
\hline 6 & Kvb & $63^{\circ} 47^{\prime} 48^{\prime \prime}$ & $148^{\circ} 15^{\prime} 10^{\prime \prime}$ & UW1583/30 & Basalt & Homblende & 0.302 & 0.3517 & - & ${ }^{4} 77.0 \pm 5.9$ & $79.1 \pm 6.0$ & $\begin{array}{l}\text { Sherwood, 1973; } \\
\text { Sherwood and } \\
\text { Craddock, } 1979 .\end{array}$ \\
\hline 7 & Kgr & $63^{\circ} 46^{\circ} 04^{*}$ & $148^{\circ} 02^{\prime} 37^{*}$ & UW1583/17 & $\begin{array}{l}\text { Monzonite } \\
\text { (Quartz } \\
\text { dionte) }\end{array}$ & Hornblende & 0.561 & 0.8397 & - & ${ }^{4} 98.4 \pm 5.5$ & $101.1 \pm 5.6$ & Do. \\
\hline 8 & Dmb & $63^{\circ} 47^{\prime} 29^{\prime \prime}$ & $147^{\circ} 59^{\prime} 50^{\prime \prime}$ & UW1580/16 & Phyllite & Muscovite & 2.818 & 4.803 & - & ${ }^{\circ} 1120=5$ & $114.6 \pm 5.1$ & $\begin{array}{l}\text { Anderson, 1973; } \\
\text { Sherwood and } \\
\text { Craddock, 1979; } \\
\text { Wilson and } \\
\text { others, } 19856 \text {. }\end{array}$ \\
\hline 9 & $\mathrm{Kgr}$ & $63^{\circ} 46^{\prime} 37^{\circ}$ & $147^{\circ} 50^{\prime} 17^{*}$ & UW1580/42 & $\begin{array}{l}\text { Grano- } \\
\text { dionite } \\
\text { (Tona- } \\
\text { lite) }\end{array}$ & Biotite & 3.671 & 3.813 & - & ${ }^{4} 68.9 \pm 2.8$ & $70.7 \pm 2.9$ & Do. \\
\hline 10 & Kgr & $63^{\circ} 44^{\prime} 24^{\prime \prime}$ & $147^{\circ} 25^{\prime} 30^{\prime \prime}$ & UW1633/87 & $\begin{array}{l}\text { Quartz } \\
\text { monzonite } \\
\text { (Granodi- } \\
\text { orite or } \\
\text { tonalite) }\end{array}$ & Homblende & 1.093 & 1.648 & - & $499.1 \pm 4.6$ & $101.8 \pm 4.7$ & $\begin{array}{l}\text { Sherwood, } 1973 \\
\text { Sherwood and } \\
\text { Craddock, } 1979 .\end{array}$ \\
\hline
\end{tabular}


Table 1. Selected potassium-argon age determinations from the Healy quadrangle, Alaska-Continued

\begin{tabular}{|c|c|c|c|c|c|c|c|c|c|c|c|c|}
\hline \multirow{2}{*}{$\begin{array}{l}\text { Map } \\
\text { No. }\end{array}$} & \multirow{2}{*}{$\begin{array}{l}\text { Map } \\
\text { unit }\end{array}$} & \multicolumn{2}{|c|}{ Location } & \multirow[t]{2}{*}{ Field No. } & \multirow{2}{*}{$\begin{array}{l}\text { Rock } \\
\text { type }\end{array}$} & \multirow{2}{*}{$\begin{array}{c}\text { Mineral } \\
\text { dated }\end{array}$} & \multirow{2}{*}{$\begin{array}{c}\mathrm{K}_{2} \mathrm{O} \\
\text { (weight } \\
\text { percent) }\end{array}$} & \multirow{2}{*}{$\begin{array}{l}{ }^{40} \mathrm{Ar}_{\text {rad }} \\
\frac{\text { moles }}{\text { gram }} \times 10^{-10}\end{array}$} & \multirow{2}{*}{$\frac{{ }^{40} \mathrm{Ar}_{\text {rad }}}{{ }^{40} \mathrm{Ar}_{\mathrm{r} \text { rad }}}$} & \multirow{2}{*}{$\begin{array}{l}\text { Previously } \\
\text { published age } \\
\text { (millions of } \\
\text { years) }\end{array}$} & \multirow{2}{*}{$\begin{array}{c}\text { Age calculated } \\
\text { using } \\
\text { constants of } \\
\text { Steiger and } \\
\text { Jager, } 1977 \\
\text { (millons of } \\
\text { years) }\end{array}$} & \multirow[b]{2}{*}{ References } \\
\hline & & Lat (N.) & Long (W.) & & & & & & & & & \\
\hline \multirow[t]{4}{*}{11} & \multirow[t]{4}{*}{$\mathrm{Kgr}$} & \multirow[t]{4}{*}{$63^{\circ} 44^{\prime} 59^{\prime \prime}$} & \multirow[t]{4}{*}{$147^{\circ} 23^{\prime} 15^{\prime \prime}$} & DT72-43A & \multirow{4}{*}{$\begin{array}{l}\text { Quartz } \\
\text { monzonite } \\
\text { (Grano- } \\
\text { dionite } \\
\text { or tona- } \\
\text { lite) }\end{array}$} & Biotte & $7.863(2)$ & 11.18 & 0.855 & $93.8 \pm 2.8$ & $96.1 \pm 2.9$ & \multirow{4}{*}{$\begin{array}{l}\text { Turner and } \\
\text { Smith, 1974; } \\
\text { Wahrhaftig and } \\
\text { others, } 1975 \text {. }\end{array}$} \\
\hline & & & & DT72-43B & & Biotite & $7.536(2)$ & 10.66 & 0.883 & $93.4 \pm 2.8$ & $95.7 \pm 2.9$ & \\
\hline & & & & DT72-43A & & Hombiende & $1.022\{2\}$ & 1.476 & 0.838 & $95.3 \pm 2.8$ & $97.6 \pm 2.9$ & \\
\hline & & & & DT72-43B & & Homblende & $0.974(2)$ & 1.401 & 0.857 & $95.0 \pm 2.8$ & $97.2 \pm 2.9$ & \\
\hline 12 & $\mathrm{Kgr}$ & $63^{\circ} 45^{\prime} 35^{\prime \prime}$ & $147^{\circ} 19^{\prime} 20^{\prime \prime}$ & DT72-44A & $\begin{array}{l}\text { Quartz } \\
\text { monzonite } \\
\text { (Granodi- } \\
\text { orite or } \\
\text { tonalite) }\end{array}$ & $\begin{array}{c}\text { Biotite } \\
\text { Hornblende }\end{array}$ & $\begin{array}{l}7.785(2) \\
1.067(2)\end{array}$ & $\begin{array}{c}10.92 \\
1.507\end{array}$ & $\begin{array}{l}0.903 \\
0.823\end{array}$ & $\begin{array}{l}92.6 \pm 2.8 \\
93.2 \pm 2.8\end{array}$ & $\begin{array}{l}94.9 \pm 2.9 \\
95.5 \pm 2.9\end{array}$ & $\begin{array}{l}\text { Tumer and } \\
\text { Smith, 1974; } \\
\text { Wahrhaftig and } \\
\text { others, 1975; } \\
\text { Wilson and } \\
\text { others, } 1985 \mathrm{~b} \text {. }\end{array}$ \\
\hline 13 & $\mathrm{Tgr}$ & $63^{\circ} 35^{\prime} 27^{\prime \prime}$ & $147^{\circ} 22^{\prime} 10^{\prime \prime}$ & DT72-45A & $\begin{array}{l}\text { Grano- } \\
\text { diorite }\end{array}$ & $\begin{array}{c}\text { Biotike } \\
\text { Hornblende }\end{array}$ & $\begin{array}{l}8.840\{2\} \\
0.679(2)\end{array}$ & $\begin{array}{l}4.878 \\
0.3910\end{array}$ & $\begin{array}{l}0.775 \\
0.729\end{array}$ & $\begin{array}{l}37.0 \pm 1.1 \\
38.5 \pm 1.1\end{array}$ & $\begin{array}{l}37.9 \pm 1.1 \\
39.6 \pm 1.1\end{array}$ & $\begin{array}{l}\text { Turner and } \\
\text { Smith, } 1974 .\end{array}$ \\
\hline 14 & Dy & $63^{\circ} 42^{\prime} 00^{N}$ & $147^{\circ} 47^{\prime} 04^{\prime \prime}$ & UW1633/43 & Phyllite & Muscovite & 4.081 & 6.485 & - & ${ }^{4} 104.0 \pm 4.0$ & $107.1 \pm 4.1$ & $\begin{array}{l}\text { Sherwood, 1979; } \\
\text { Sherwood and } \\
\text { Craddock, } 1979 .\end{array}$ \\
\hline 15 & Tcv & $63^{\circ} 42^{\prime} 25^{\prime \prime}$ & $148^{\circ} 10^{\prime} 20^{\prime \prime}$ & UW1583/18 & Dacite & Homblende & 0.882 & 0.8357 & $\longrightarrow$ & ${ }^{4} 62.9 \pm 3.3$ & $64.6 \pm 3.4$ & $\begin{array}{l}\text { Sherwood, 1973; } \\
\text { Sherwood and } \\
\text { Craddock, } 1979 .\end{array}$ \\
\hline 16 & Tgr & $63^{\circ} 38^{\prime} 18^{\prime \prime}$ & $148^{\circ} 29^{\prime} 50^{\prime}$ & UW1574/17 & $\begin{array}{l}\text { Quartz } \\
\text { diorite } \\
\text { (Tona- } \\
\text { lite) }\end{array}$ & Amphibole & 0.421 & 0.2247 & - & ${ }^{4} 35.7 \pm 2.8$ & $36.7 \pm 2.9$ & $\begin{array}{l}\text { Hickman, 1974; } \\
\text { Sherwood and } \\
\text { Craddock, } 1979 .\end{array}$ \\
\hline 17 & TKgr & $63^{\circ} 38^{\prime} 22^{\prime \prime}$ & $148^{\circ} 47^{\prime} 50^{\prime \prime}$ & UW1574/3 & $\begin{array}{l}\text { Grano- } \\
\text { dionite }\end{array}$ & Blotite & 1.435 & 1.661 & - & ${ }^{4} 76.6 \pm 3.5$ & $78.7 \pm 3.6$ & Do. \\
\hline 18 & Tev & $63^{\circ} 43^{\prime} 40^{\prime}$ & $148^{\circ} 42^{\prime} 00^{\prime}$ & UW1563/2 & Basalt & $\begin{array}{l}\text { Whole } \\
\text { rock }\end{array}$ & 2.408 & 1.7882 & - & ${ }^{4} 49.5 \pm 2.1$ & $50.9 \pm 2.2$ & $\begin{array}{l}\text { Bultman, 1972; } \\
\text { Sherwood and } \\
\text { Craddock, } 1979 .\end{array}$ \\
\hline 19 & Tcr & $63^{\circ} 41^{\prime} 42^{\prime \prime}$ & $148^{\circ} 47^{\prime} 10^{\circ}$ & Uw1563/4 & Diabase & $\begin{array}{l}\text { Whole } \\
\text { rock }\end{array}$ & 0.908 & 0.8025 & - & ${ }^{4} 58.8 \pm 3.0$ & $60.4 \pm 3.1$ & Do. \\
\hline 20 & Tvim & $63^{\circ} 45^{\prime} 20^{\prime \prime}$ & $148^{\circ} 53^{\prime} 48^{\prime \prime}$ & UW1563/3 & Basalt & $\begin{array}{l}\text { Whole } \\
\text { rock }\end{array}$ & 2.324 & 1.8565 & - & ${ }^{4} 53.2 \pm 2.3$ & $54.7 \pm 2.4$ & $\begin{array}{l}\text { Bultman, 1972; } \\
\text { Sherwood and } \\
\text { Craddock, 1979; } \\
\text { Wilson and } \\
\text { others, 1985b. }\end{array}$ \\
\hline
\end{tabular}




\begin{tabular}{|c|c|c|c|c|c|c|c|c|c|c|c|c|c|}
\hline & 21 & Tcv & $63^{\circ} 36^{\prime} 43^{\prime \prime}$ & $149^{\circ} 35^{\prime} 25^{\prime \prime}$ & UW1562/3 & Basalt & $\begin{array}{l}\text { Whole } \\
\text { rock }\end{array}$ & 2.549 & 2.1102 & - & ${ }^{4} 55.1 \pm 2.3$ & $56.6 \pm 2.4$ & $\begin{array}{l}\text { Hickman, 1974; } \\
\text { Hickman and } \\
\text { Craddock, } 1976 .\end{array}$ \\
\hline & 22 & Tcv & $63^{\circ} 32^{\prime} 15^{\prime \prime}$ & $149^{\circ} 49^{\prime} 00^{\prime \prime}$ & DT73-1 & $\begin{array}{l}\text { Quartz } \\
\text { diorite }\end{array}$ & Plagioclase & $\begin{array}{l}0.319 \pm \\
0.002(2)\end{array}$ & 0.274 & 0.661 & $57.2 \pm 3.4$ & $58.7 \pm 3.5$ & $\begin{array}{l}\text { Gilbert and } \\
\text { others, } 1976 .\end{array}$ \\
\hline & 23 & Tcr & $63^{\circ} 30^{\prime} 24^{\prime \prime}$ & $149^{\circ} 38^{\prime} 20^{\prime \prime}$ & 74WG-14 & Basalt & $\begin{array}{l}\text { Whole } \\
\text { rock }\end{array}$ & $2.30\{2\}$ & 1.436 & 0.480 & $\begin{array}{l}41.8 \\
\text { Mintmum age }\end{array}$ & $\begin{array}{l}42.9 \\
\text { Minimum age }\end{array}$ & Do. \\
\hline & 24 & Tev & $63^{\circ} 34^{\prime} 20^{\prime \prime}$ & $149^{\circ} 36^{\prime} 29^{\prime \prime}$ & DT73-9 & Andesite & Plagioclase & $\begin{array}{l}0.605 \pm \\
0.005(2)\end{array}$ & 5 & 5 & $\begin{array}{l}60.6 \\
\text { Minimum age }\end{array}$ & $\begin{array}{l}{ }^{3} 62.2 \\
\text { Minimum age }\end{array}$ & Do. \\
\hline & 25 & Tev & $63^{\circ} 36^{\prime} 13^{\prime \prime}$ & $149^{\circ} 28^{\prime} 11^{\prime \prime}$ & UW1562/4 & Basalt & $\begin{array}{l}\text { Whole } \\
\text { rock }\end{array}$ & 1.661 & 1.483 & - & $59.3 \pm 2.7$ & $61.0 \pm 2.8$ & $\begin{array}{l}\text { Wegnex, 1972; } \\
\text { Hickman, 1974; } \\
\text { Hickman and } \\
\text { Craddock, } 1976 .\end{array}$ \\
\hline & 26 & TKgr & $63^{\circ} 34^{\prime} 24^{\prime \prime}$ & $149^{\circ} 01^{\prime} 54^{\prime \prime}$ & UW1574/7 & $\begin{array}{l}\text { Grano- } \\
\text { diorite }\end{array}$ & Biotite & 6.776 & 7.1525 & - & ${ }^{4} 70.0 \pm 2.6$ & $71.9 \pm 2.7$ & $\begin{array}{l}\text { Hickman, 1974; } \\
\text { Hickman and } \\
\text { Craddock, } 1976 .\end{array}$ \\
\hline & 27 & Tgr & $63^{\circ} 28^{\prime} 57^{\prime \prime}$ & $148^{\circ} 36^{\prime} 45^{\prime \prime}$ & UW1553/4 & $\begin{array}{l}\text { Grano- } \\
\text { diorite } \\
\text { (Granite) }\end{array}$ & Biotite & 6.396 & 3.650 & - & ${ }^{4} 38.1 \pm 1.4$ & $39.2 \pm 1.4$ & $\begin{array}{l}\text { Hickman, 1971: } \\
\text { Sherwood and } \\
\text { Craddock, } 1979 .\end{array}$ \\
\hline & 28 & Tgr & $63^{\circ} 28^{\prime} 55^{\prime \prime}$ & $148^{\circ} 29^{\prime} 20^{\prime \prime}$ & 72ASt-332 & $\begin{array}{l}\text { Quartz } \\
\text { monzonite } \\
\text { (Granite) }\end{array}$ & Biotike & $8.460\{2\}$ & 4.665 & 0.693 & $36.9 \pm 1.1$ & $37.9 \pm 1.1$ & $\begin{array}{l}\text { Tumer and } \\
\text { Smith, 1974; }\end{array}$ \\
\hline \multirow[t]{9}{*}{$\stackrel{\omega}{\omega}$} & 29 & Tgr & $63^{\circ} 27^{\prime} 02^{\prime \prime}$ & $148^{\circ} 26^{\prime} 08^{\prime \prime}$ & UW1574/18 & Granite & Biotite & 5.560 & 4.650 & - & ${ }^{4} 55.7 \pm 2.2$ & $57.2 \pm 2.3$ & $\begin{array}{l}\text { Hickman, 1974; } \\
\text { Sherwood and } \\
\text { Craddock, } 1979 .\end{array}$ \\
\hline & 30 & Tgr & $63^{\circ} 24^{\prime} 55^{\prime \prime}$ & $148^{\circ} 00^{\prime} 55^{\prime \prime}$ & 72ASt-351 & Granite & Biotite & $6.996(2)$ & 5.858 & 0.875 & $55.8 \pm 1.7$ & $57.2 \pm 1.7$ & $\begin{array}{l}\text { Tumer and } \\
\text { Smith, } 1974 .\end{array}$ \\
\hline & 31 & Tgr & $63^{\circ} 26^{\prime} 42^{\prime \prime}$ & $147^{\circ} 54^{\prime} 37^{*}$ & UW1596/26 & $\begin{array}{l}\text { Quartz } \\
\text { monzonite } \\
\text { (Granite) }\end{array}$ & Biotite & 4.538 & 3.8325 & - & ${ }^{4} 56.2 \pm 2.2$ & $57.7 \pm 2.3$ & $\begin{array}{l}\text { Rautman, 1974; } \\
\text { Sherwood and } \\
\text { Craddock, } 1979 .\end{array}$ \\
\hline & 32 & Tgr & $63^{\circ} 31^{\prime} 35^{\prime \prime}$ & $147^{\circ} 40^{\prime} 10^{\prime \prime}$ & 72ASt-331 & $\begin{array}{l}\text { Quartz } \\
\text { monzonite } \\
\text { (Granite } \\
\text { or grano- } \\
\text { diorite) }\end{array}$ & Biotite & $8.863(2)$ & 4.841 & 0.835 & $36.6 \pm 1.1$ & $37.5 \pm 1.1$ & $\begin{array}{l}\text { Turner and } \\
\text { Smith, } 1974 .\end{array}$ \\
\hline & 33 & Kgr & $63^{\circ} 32^{\prime} 50^{\prime \prime}$ & $147^{\circ} 26^{\prime} 30^{\circ}$ & $81 A C y-66$ & Tonalite & Homblende & \multicolumn{2}{|c|}{ By the ${ }^{40} \mathrm{Ar}{ }^{39} \mathrm{Ar}$ method } & 0.147 & - & $105.7 \pm 3.3$ & This report \\
\hline & 34 & KCS & $63^{2} 25^{\prime} 55^{\circ}$ & $147^{\circ} 26^{\prime} 45^{\circ}$ & $72 \mathrm{ASt}-329$ & $\begin{array}{l}\text { Amphi- } \\
\text { bolite } \\
\text { gneiss }\end{array}$ & Amphibole & 0.210 & 0.2223 & 0.272 & $70.3 \pm 2.1$ & $72.1 \pm 2.2$ & $\begin{array}{l}\text { Tumer and } \\
\text { Smith, } 1974 .\end{array}$ \\
\hline & 35 & Kgr & $63^{\circ} 28^{\prime} 10^{\prime \prime}$ & $147^{\circ} 16^{\prime} 20^{\prime \prime}$ & $72 \mathrm{ASt}-326$ & $\begin{array}{l}\text { Quart } \\
\text { diorite }\end{array}$ & $\begin{array}{c}\text { Biotite } \\
\text { Hormblende }\end{array}$ & $\begin{array}{l}8.836(2) \\
0.597 \pm \\
0.003(4)\end{array}$ & $\begin{array}{l}7.062 \\
0.7900\end{array}$ & $\begin{array}{l}0.862 \\
0.637\end{array}$ & $\begin{array}{l}53.3 \pm 1.6 \\
87.4 \pm 2.6\end{array}$ & $\begin{array}{l}54.7 \pm 1.6 \\
89.6 \pm 2.7\end{array}$ & Do. \\
\hline & 36 & Kgr & $63^{\circ} 29^{\prime} 15^{\prime \prime}$ & $147^{\circ} 10^{\prime} 10^{\circ}$ & DT73-208 & $\begin{array}{l}\text { Diorite } \\
\text { gneiss }\end{array}$ & $\begin{array}{c}\text { Biotite } \\
\text { Homblende }\end{array}$ & $\begin{array}{l}8.438(2) \\
0.685(2)\end{array}$ & $\begin{array}{l}6.383 \\
0.6063\end{array}$ & $\begin{array}{l}0.906 \\
0.658\end{array}$ & $\begin{array}{l}50.2 \pm 1.5 \\
59.9 \pm 1.8\end{array}$ & $\begin{array}{l}51.8 \pm 1.5 \\
60.8 \pm 1.8\end{array}$ & Do. \\
\hline & 37 & Kcs & $63^{\circ} 29^{\prime} 58^{\prime \prime}$ & $147^{\circ} 08^{\prime} 55^{\prime \prime}$ & 72ASt-323 & $\begin{array}{l}\text { Amphi- } \\
\text { bolite } \\
\text { gneiss }\end{array}$ & Homblende & $\begin{array}{l}0.602 \pm \\
0.006(4)\end{array}$ & 0.7026 & 0.743 & $77.3 \pm 2.3$ & $79.3 \pm 2.4$ & Do. \\
\hline
\end{tabular}


Table 1. Selected potassium-argon age determinations from the Healy quadrangie, Alaska-Continued

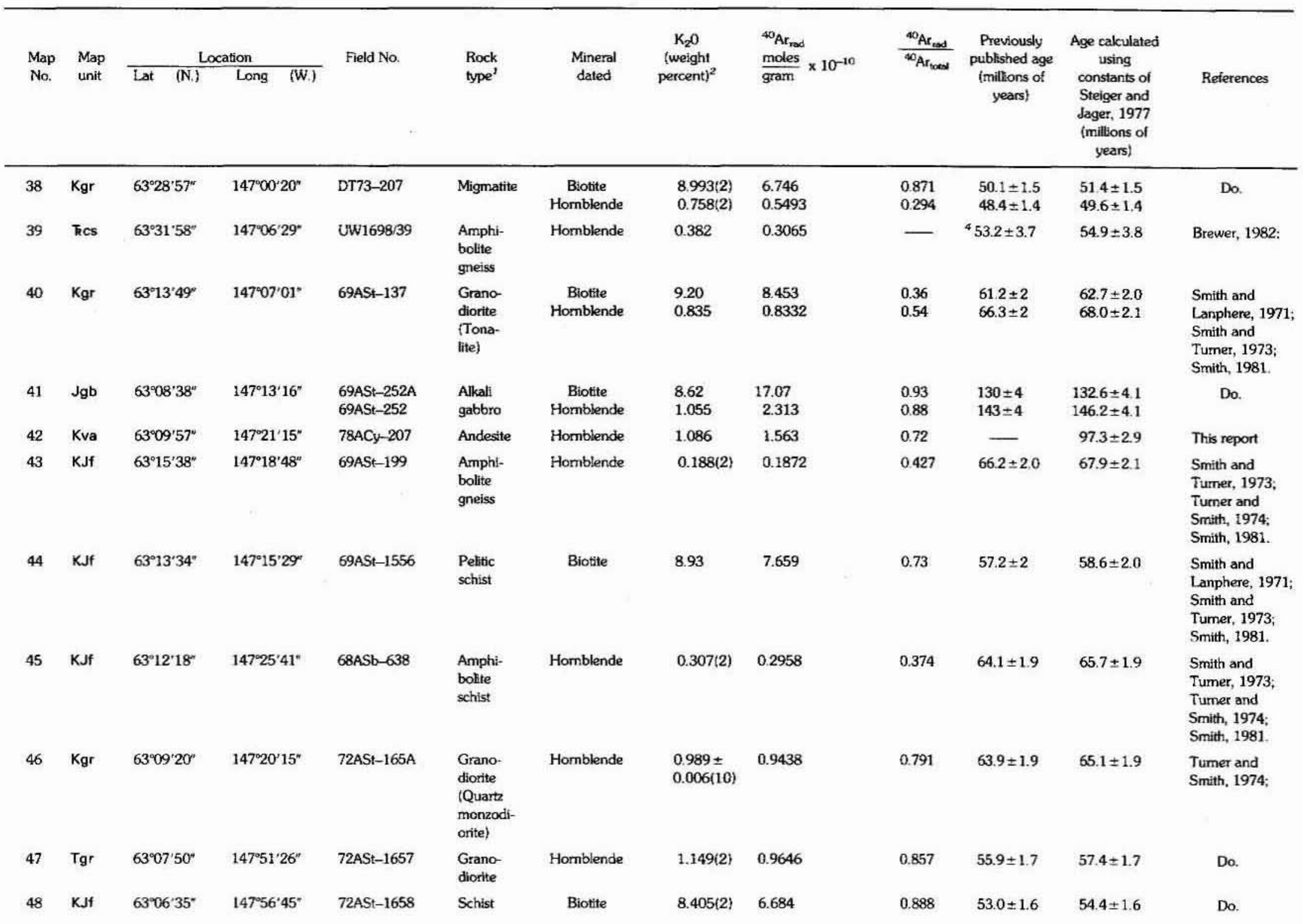




\begin{tabular}{|c|c|c|c|c|c|c|c|c|c|c|c|c|}
\hline 49 & Tgr & $63^{\circ} 01^{\prime} 45^{\prime \prime}$ & $148^{\circ} 04^{\prime} 05^{\prime \prime}$ & $72 \mathrm{ASt}-178$ & $\begin{array}{l}\text { Grano- } \\
\text { diorite }\end{array}$ & $\begin{array}{c}\text { Biotite } \\
\text { Homblende }\end{array}$ & $\begin{array}{l}8.916\{2\} \\
0.520(4)\end{array}$ & $\begin{array}{l}6.515 \\
0.3487\end{array}$ & $\begin{array}{l}0.779 \\
0.571\end{array}$ & $\begin{array}{l}48.8 \pm 1.5 \\
44.8 \pm 1.3\end{array}$ & $\begin{array}{l}50.1 \pm 1.5 \\
46.0 \pm 1.3\end{array}$ & Do. \\
\hline 50 & Kgr & $63^{\circ} 00^{\prime} 26^{\prime \prime}$ & $148^{\circ} 27^{\prime} 40^{\prime \prime}$ & TT-4-72 & $\begin{array}{l}\text { Quarte } \\
\text { diorite }\end{array}$ & Biotite & $8.116(2)$ & 6.899 & 0.695 & $57.6 \pm 1.7$ & $58.1 \pm 1.7$ & Do. \\
\hline 51 & $\mathrm{Kgr}$ & $63^{\circ} 01^{\prime} 40^{\prime \prime}$ & $148^{\circ} 29^{\prime} 35^{\prime \prime}$ & TT-6-72 & $\begin{array}{l}\text { Quartz } \\
\text { diorite }\end{array}$ & Biotite & $7.929(2)$ & 6.788 & 0.796 & $57.1 \pm 1.7$ & $58.5 \pm 1.7$ & Do. \\
\hline 52 & Tvv & $63^{\circ} 10^{\prime} 31^{\prime \prime}$ & $149^{\circ} 03^{\prime} 18^{\prime \prime}$ & $78 \mathrm{AC} y-203 \mathrm{~B}$ & Rhyolite & Sanidine & 9.07 & 7.145 & 0.80 & - & $53.9 \pm 1.6$ & This report \\
\hline 53 & Tgr & $63^{\circ} 27^{\prime} 54^{\prime \prime}$ & $148^{\circ} 43^{\prime} 57^{\prime \prime}$ & UW1553/7 & $\begin{array}{l}\text { Grano- } \\
\text { diorte }\end{array}$ & Biotite & 6.480 & 5.675 & - & ${ }^{4} 58.3 \pm 2.0$ & $59.8 \pm 2.1$ & $\begin{array}{l}\text { Hickman, 1971: } \\
\text { Hickman and } \\
\text { Craddock, } 1976 .\end{array}$ \\
\hline 54 & TKgr & $63^{\circ} 16^{\prime} 35^{*}$ & $149^{\circ} 24^{\prime} 50^{\prime \prime}$ & $76 \mathrm{DS}-1$ & $\begin{array}{l}\text { Quart } \\
\text { monzonite }\end{array}$ & Biotite & $\begin{array}{l}7.098 \pm \\
0.142\{4\rangle\end{array}$ & 7.150 & 0.818 & $67.0 \pm 2.0$ & $68.6 \pm 2.0$ & $\begin{array}{l}\text { Swainbank and } \\
\text { others, } 1977 \text {. }\end{array}$ \\
\hline 55 & TKgr & $63^{\circ} 16^{\prime} 33^{\prime \prime}$ & $149^{\circ} 26^{\prime} 30^{\prime \prime}$ & $76 \mathrm{DS}-2$ & $\begin{array}{l}\text { Intrusive } \\
\text { breccia }\end{array}$ & Biotite & $\begin{array}{l}8.777 \pm \\
0.033(4)\end{array}$ & 8.226 & 0.768 & $62.4 \pm 1.8$ & $64.0 \pm 1.8$ & Do. \\
\hline 56 & TKgr & $63^{\circ} 16^{\prime} 32^{\prime \prime}$ & $149^{\circ} 28^{\prime} 05^{\prime \prime}$ & $76 \mathrm{DS}-3$ & Diorite & $\begin{array}{c}\text { Altered } \\
\text { homblende } \\
\text { Altered } \\
\text { homblende }\end{array}$ & $\begin{array}{l}2.729 \pm \\
0.011(4) \\
2.043 \pm \\
0.057(4)\end{array}$ & $\begin{array}{l}2.350 \\
1.878\end{array}$ & $\begin{array}{l}0.841 \\
0.764\end{array}$ & $\begin{array}{c}57.4 \pm 1.7 \\
\text { Minimum age } \\
61.2 \pm 1.8 \\
\text { Minimum age }\end{array}$ & $\begin{array}{c}58.8 \pm 1.7 \\
\text { Minimum age } \\
62.7 \pm 1.8 \\
\text { Minimum age }\end{array}$ & Do. \\
\hline \multirow[t]{3}{*}{57} & TKgr & $63^{\circ} 12^{\prime} 55^{\prime \prime}$ & $149^{\circ} 38^{\prime} 50^{\circ}$ & 71ASt-264A & $\begin{array}{l}\text { Dionite } \\
\text { porphyry }\end{array}$ & Biotite & $8.343(2)$ & 8.644 & 0.837 & $68.2 \pm 2.1$ & $70.6 \pm 2.2$ & Do \\
\hline & & & & 71ASt-265 & $\begin{array}{l}\text { Altered } \\
\text { breccia } \\
\text { pipe }\end{array}$ & Muscovite & $9.359\{2\}$ & 9.577 & 0.940 & $68.0 \pm 2.0$ & $69.7 \pm 2.1$ & \\
\hline & & & & 71ASt-263 & $\begin{array}{l}\text { Diorite } \\
\text { porphyry }\end{array}$ & Biotite & $8.328(2)$ & 8.583 & 0.940 & $68.5 \pm 2.1$ & $70.2 \pm 2.2$ & \\
\hline
\end{tabular}

There applicable, following originally published rock name, in parentheses is revised rock name according to the IUGS nomenclature of 1973 , or what is suggested by subsequent modal analyses from same plutonic body.

(t)

${ }^{3}$ Age recalculated from previously published age using method Jescribed by Dalrymple (1979).

${ }^{4}$ Age determination and corresponding potassium analysis and argon measurement performed by Krueger Enterprises, Inc. Original potassium and argon values were reported in

${ }^{40} \mathrm{~K} \mathrm{ppm}$ and ${ }^{40} \mathrm{Ar}_{\text {rad }} \mathrm{ppm}$ and have been recalculated in this report to $\mathrm{K}_{2} 0$ weight percent and moles $/ \mathrm{gram} \times 10^{10} \mathrm{respectively.}$

SData omitted because of suspected typographical error in Gilbert and others (1976).

NOTE.-For sample under map No. 33, argon analyses and age calculation by L.B.G. Pickthorn; for samples under map Nos. 42 and 52, potassium analyses by Mark Taylor, argon analyses and age calculations by M.L. Silberman and L.B. Gray. 
Table 2. Fossil data from the Healy quadrangie, Alaska NOTE. - See map B, sheet 2 for localities

[All available fossil data for the Healy quadrangle were considered in compiling this table. Localities are grouped and consecutively numbered according to geologic map unit, from the stratigraphically youngest unit to the oldest SEM, scanning electron microscope; analyst, Robert L. Oscarson, USGS. CAI, color alteration index. Indices and corresponding temperature ranges: $1,50-80{ }^{\circ} \mathrm{C} ; 1.5,50-90{ }^{\circ} \mathrm{C} ; 2,60-140{ }^{\circ} \mathrm{C} ; 3,110-200{ }^{\circ} \mathrm{C} ; 4,190-300{ }^{\circ} \mathrm{C} ; 5,350-400{ }^{\circ} \mathrm{C} ; 6,350-450{ }^{\circ} \mathrm{C} ; 7,400-500{ }^{\circ} \mathrm{C} ; 8,450-550$ ${ }^{\circ} \mathrm{C}$ (Epstein and others, 1977). Ak DGGS, Alaska Division of Geological and Geophysical Surveys; USGS, United States Geological Survey]

\begin{tabular}{|c|c|c|c|c|c|c|c|}
\hline $\begin{array}{l}\text { Map No., } \\
\text { map unit, } \\
\text { quad. No. }\end{array}$ & $\begin{array}{l}\text { Location } \\
\text { lat (N.) and } \\
\text { long (W.) }\end{array}$ & $\begin{array}{l}\text { Field No. (s), } \\
\text { (USGS Museum No.), } \\
\text { and (or) collector }\end{array}$ & Lithology & Fossits & $\begin{array}{l}\text { Fossil } \\
\text { age }\end{array}$ & $\begin{array}{l}\text { Determiner } \\
\text { and (or) reference }\end{array}$ & Comments \\
\hline $\begin{array}{c}1 \\
\text { Tcb } \\
\text { B-6 }\end{array}$ & $\begin{array}{l}63^{\circ} 16^{\prime} 18^{\prime \prime} \\
149^{\circ} 31^{\prime} 09^{\prime \prime}\end{array}$ & $\begin{array}{l}67 \text { ACx-190 } \\
\text { (Paleobot. loc. } \\
\text { 11120); } 80 \text { AMM-28 }\end{array}$ & $\begin{array}{l}\text { Argillaceous } \\
\text { sandstone and } \\
\text { siltstone. }\end{array}$ & $\begin{array}{l}\text { Plant fossils including: } \\
\text { Onociea sp. } \\
\text { Metasequoia cf. M. glyptostroboides } \\
\text { Cenidiphyllum crenatum } \\
\text { Zelkova browni } \\
\text { Alnus evidens } \\
\text { Betuia sp. } \\
\text { Carpinus seldoviana? } \\
\text { Corylus hamimani } \\
\text { Populus kenaiana } \\
\text { Salix sp. } \\
\text { Alangium mikii } \\
\text { Monocotylophylitum sp. }\end{array}$ & $\begin{array}{l}\text { Late } \\
\text { Oligocene } \\
\text { or } \\
\text { early } \\
\text { Miocene. }\end{array}$ & $\begin{array}{l}\text { J.A. Wolfe in } \\
\text { Hawley and Clark, } \\
\text { 1974; M.W. } \\
\text { Mullen, this } \\
\text { report. }\end{array}$ & $\begin{array}{l}\text { Specimens coliected near top } \\
\text { of section at Dunkle coal } \\
\text { Mine. Recollected in } 1980 \\
\text { during coal assessment } \\
\text { study by G.D. Stricker of } \\
\text { the USGS }\end{array}$ \\
\hline $\begin{array}{l}2 \\
\text { Tcb } \\
\text { D-3 }\end{array}$ & $\begin{array}{l}63^{\circ} 57^{\prime} 09^{\prime \prime} \\
148^{\circ} 18^{\prime} 48^{\prime \prime}\end{array}$ & 80 AMM-29 & $\begin{array}{l}\text { Claystone and } \\
\text { mudstone. }\end{array}$ & $\begin{array}{l}\text { Ainus sp. } \\
\text { Salix sp. } \\
\text { Monocotylophylium sp. }\end{array}$ & $\begin{array}{l}\text { Oligo- } \\
\text { cene\{?\}. }\end{array}$ & $\begin{array}{l}\text { M.W. Mullen, } \\
\text { this report. }\end{array}$ & $\begin{array}{l}\text { Healy Creek Fm, on Dexter } \\
\text { Creek. }\end{array}$ \\
\hline $\begin{array}{l}3 \\
\text { Tcb } \\
D-2\end{array}$ & $\begin{array}{l}63^{\circ} 59^{\prime} 21^{\prime \prime} \\
147^{\circ} 50^{\prime} 06^{\prime \prime}\end{array}$ & 80 AMM-30 & Mudstone & $\begin{array}{l}\text { Metasequoia sp. } \\
\text { Alnus? sp. } \\
\text { Saitix sp. }\end{array}$ & do. & do. & $\begin{array}{l}\text { Healy Creek Fm. near Coal } \\
\text { Creek and Mystic Mtn. }\end{array}$ \\
\hline $\begin{array}{l}4 \\
\text { Ts } \\
\text { B-4 }\end{array}$ & $\begin{array}{l}63^{\circ} 22^{\prime} 00^{\prime \prime} \\
148^{\circ} 51^{\prime} 30^{\prime \prime}\end{array}$ & $81 A C y-3$ & Sandstone & $\begin{array}{l}\text { Indeterminate fossil-plant } \\
\text { fragments }\end{array}$ & Tertiary & do. & $\begin{array}{l}\text { From poorly consolidated } \\
\text { outcrops on the banks of } \\
\text { Jack River. }\end{array}$ \\
\hline $\begin{array}{c}5 \\
\text { Tfv } \\
\text { B-6 }\end{array}$ & $\begin{array}{l}63^{\circ} 18^{\prime} 44^{\prime \prime} \\
149^{\circ} 38^{\prime} 55^{\prime \prime}\end{array}$ & $82 \mathrm{AC}_{\mathrm{y}-1}$ & $\begin{array}{l}\text { Limestone } \\
\text { clasts in } \\
\text { conglomerate. }\end{array}$ & $\begin{array}{l}\text { Conodonts: } \\
\text { Paimatolepis transitans } \\
\text { Polygnathus xylus } \\
\text { Polygnathus sp. } \\
\text { Ramiform elements }\end{array}$ & $\begin{array}{l}\text { Early } \\
\text { Late } \\
\text { Devonian } \\
\text { fearly to } \\
\text { middle } \\
\text { Frasnian). }\end{array}$ & do. & $\begin{array}{l}\text { Similar fauna in } 82 \text { AMM-7A, } \\
\text { map no. } 8 \text {. CAl-6. }\end{array}$ \\
\hline $\begin{array}{l}6 \\
\text { Tfv } \\
\text { B-6 }\end{array}$ & $\begin{array}{l}63^{\circ} 18^{\prime} 20^{\prime \prime} \\
149^{\circ} 40^{\prime} 35^{\prime \prime}\end{array}$ & $\begin{array}{l}81 \mathrm{AC}_{\mathrm{y}-1,2} \\
82 \mathrm{AMM}-1\end{array}$ & $\begin{array}{l}\text { Shale inter- } \\
\text { bed in con- } \\
\text { glomerate. }\end{array}$ & $\begin{array}{l}\text { Plant fossils including: } \\
\text { Metasequoia occidentalis } \\
\text { Undeternined broad-leaf } \\
\text { specimens }\end{array}$ & $\begin{array}{l}\text { Early } \\
\text { Eocene(?). }\end{array}$ & $\begin{array}{l}\text { J.A. Wolfe, oral } \\
\text { commun., 1982, } \\
1984 \text {. }\end{array}$ & $\begin{array}{l}\text { A more detailed dermination } \\
\text { by J.A. Wolie, USGS, } \\
\text { is still pending. }\end{array}$ \\
\hline $\begin{array}{l}7 \\
\mathrm{FfV}\end{array}$ & $\begin{array}{l}63^{\circ} 18^{\prime} 27^{\prime \prime} \\
149^{\circ} 42^{\prime} 38^{\prime \prime}\end{array}$ & 82 AMM-9 & do. & $\begin{array}{l}\text { Plant fragments including: } \\
\text { Monocotylophyllum? sp. }\end{array}$ & do. & $\begin{array}{l}\text { M.W. Muilen, } \\
\text { this report. }\end{array}$ & \\
\hline
\end{tabular}


Limesto

conglomerate

83 ACy-6A

$83 \mathrm{AC} y-6 \mathrm{~B}$

$63^{\circ} 26^{\prime} 45^{\prime \prime}$

83 ACy-6C
Conodonts:

7A. Paimatolepis trensitans

Paimatolepis punctata

Palmatolepis of. $P$. follaceo

Polygnathus xylus

Polygnathus cf. P. webbi

Polygnathus sp.

Ancyrognathus? sp.

7B: Panderodus sp.

Indeterminate fragments

Conodonts:

6A: Ozarkodina sp.

B: Ozarkodina remscheidensis eosteinhomensis Pedavis sp.

Icthyoliths (fish skeletal elements) selachilian denticles and placoderm plate fragments Brachiopod fragments

6C: Pelekysgnathus sp.

Conodonts:

7A: Ozarkodina sp.

$$
\text { Distomodus sp. }
$$

7B. Ozarkodina sp.

Panderodus $\mathrm{sp}$.

Distomodus sp.

Petekysgnathus sp.

Tentaculites sp.

Ostracodes, sp. indeterminate

do

Conodonts:

Ozarkadina sp.

Panderodus sp.

Siltstone and

Plant fossils including

Alnus sp.

Limestone Conodonts:

Neogondolella polygnathiformis

Epigondoleffa primitio

Cypriodella sp

Siltstone

Plant fossils including

Metasequoia sp.

Metasequoia sp.
Dicotylophyllum flexuasa

\section{Ordovician}

Devonian.

Silurian M.W. Mullen,

Early
Late
Devonian
(early to
middle
Frasnian).

Ordovician
to
Devonian.

M.W. Mullen.

and C.A.

Sandberg,

this report

(n)

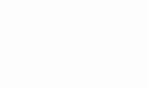

to Early and $A$.

Devonian: G. Harris,

Early

G. Harris,
this report.

Devonian.
Late

Silurian

Late

Silurian

to Early

Devanian.

Late

Silur-

ian.

Ordovician

to Early

Devonian.

Paleocenet?\} M.W. Mullen, this report

Late
Triassic
(late
Kamian to
Norian).

do.

Norian!.

Paleocene(?) J.A. Wolfe in

$$
\text { Sherwood and }
$$

The Palmatolepis assem-

blage has never been reported within the quadrangle. The most similiar faunas occur in un (map no 157) and Dmb (map no 149! in the Dimb imap no. 149) in the northem part of the quad rangle. The Panderodus assermblage also $\propto$ ccurs in limestone pebbles in unit Tcs (map no. 10) north of the McKinley fault and in limestone pebbles and blocks in units KJfl imap nos 37 38) and Kmn (map n. 55 CAI 4 .

The limestone clasts were to the south of this local-

ity. $\mathrm{CAl}-6$.
Do.

Do.

The limestone clasts probably were derived from the unit kcs occurring about $10 \mathrm{~km}$ to the north of this locality. CAI-5. 
Table 2. Fossil data from the Healy quadrangle, Alaska-Continued

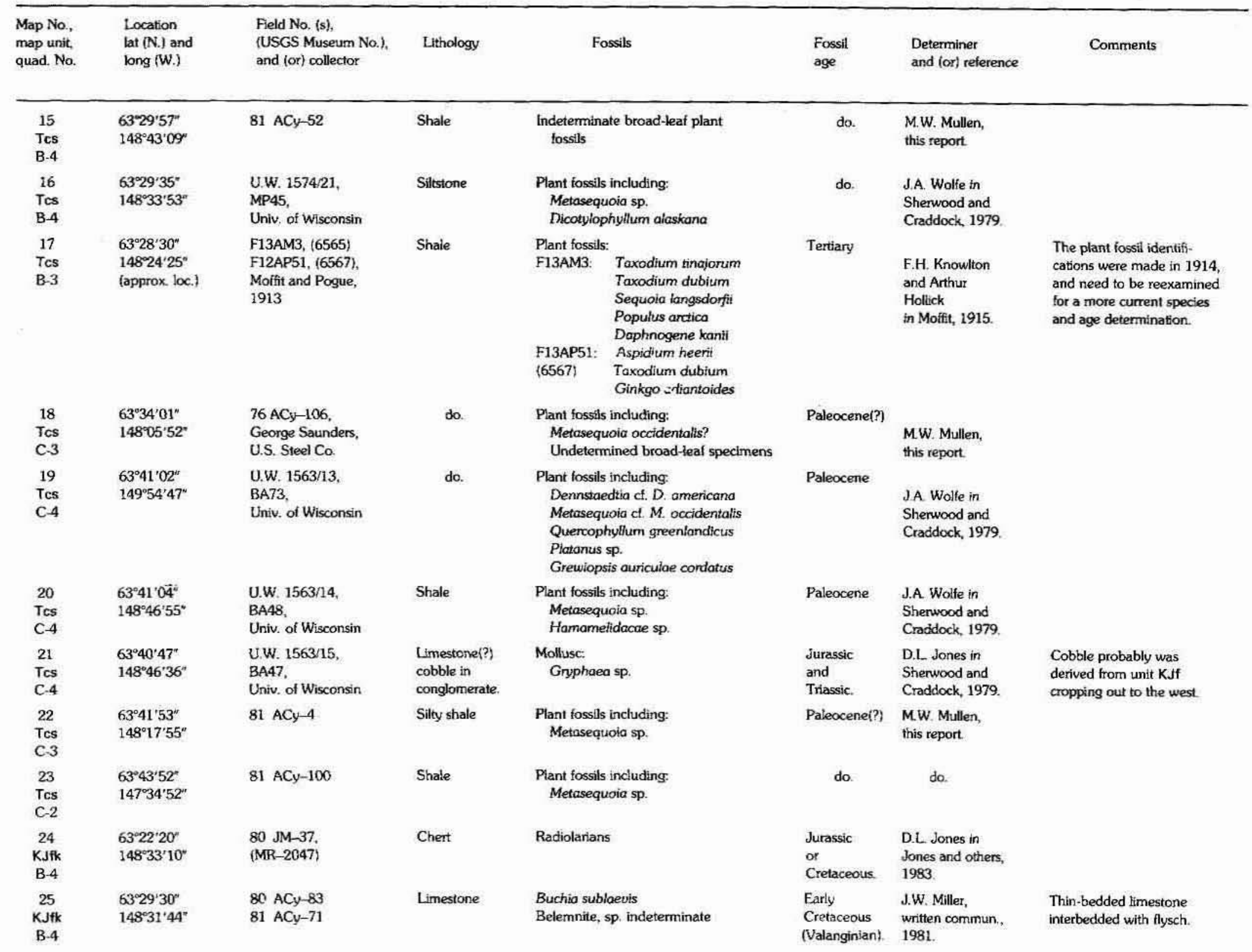




\begin{tabular}{|c|c|c|c|c|c|c|c|}
\hline $\begin{array}{c}26 \\
\text { KJik } \\
\text { B-4 }\end{array}$ & $\begin{array}{l}63^{\circ} 16^{\prime} 53^{\prime \prime} \\
148^{\circ} 49^{\prime} 14^{\prime \prime} \\
\text { (approx loc.) }\end{array}$ & $\begin{array}{l}\text { Bruce Castle of } \\
\text { Anchorage, Alaska }\end{array}$ & do. & Buchia sublaevis & do. & $\begin{array}{l}\text { D. L. Jones in } \\
\text { dones and others, } \\
1980\end{array}$ & $\begin{array}{l}\text { Limestone float within } \\
\text { outcrop area of unit } \\
\text { KJfk. }\end{array}$ \\
\hline $\begin{array}{c}27 \\
\mathrm{KJcg} \\
\mathrm{A}-2\end{array}$ & $\begin{array}{l}63^{\circ} 00^{\prime} 06^{\prime \prime} \\
147^{\circ} 51^{\prime} 15^{\prime \prime}\end{array}$ & $\begin{array}{l}72 \text { Ast-2759, } \\
\text { (M-6086), } \\
\text { T.E. Smith, Ak DGGS. } \\
\text { D.L. Jones, USGS }\end{array}$ & Shale & $\begin{array}{l}\text { Buchia nugosa and other Buchia spp. } \\
\text { Oxytoma sp. } \\
\text { Pieuromya? sp. } \\
\text { Pectinid clam } \\
\text { Ditripa? sp. (worm nube) }\end{array}$ & $\begin{array}{l}\text { Late } \\
\text { Jurassic } \\
\text { (Kimmerid- } \\
\text { gian to } \\
\text { Early Cre- } \\
\text { taceous } \\
\text { Nalangin- } \\
\text { ian). }\end{array}$ & $\begin{array}{l}\text { D.L. Jones in } \\
\text { Stberling and } \\
\text { others, 1981a; } \\
\text { Smith and others, } \\
\text { 1984; D. L Jones, } \\
\text { oral. commun., } \\
1985 .\end{array}$ & $\begin{array}{l}\text { This section contains } \\
\text { several Buchia sp. in a } \\
\text { biostratigraphic sequence. }\end{array}$ \\
\hline $\begin{array}{l}28 \\
\mathrm{KJa} \\
\mathrm{A}-6\end{array}$ & $\begin{array}{l}63^{\circ} 11^{\prime} 50^{\prime} \\
149^{\circ} 48^{\prime} 28^{\prime \prime}\end{array}$ & $\begin{array}{l}76 \text { ACy-133 } \\
F X-10\end{array}$ & $\begin{array}{l}\text { Chert, } \\
\text { argillite. }\end{array}$ & $\begin{array}{l}\text { Praeconocuryomma mamillaria } \\
\text { and other radiolarians; and } \\
\text { blvalve mollusc fragments. }\end{array}$ & $\begin{array}{l}\text { Late } \\
\text { Jurassic }\end{array}$ & $\begin{array}{l}\text { E.A. Pessagno in } \\
\text { Jones and others, } \\
1980, \text { Hawley and } \\
\text { Clark, 1974, p. B7. }\end{array}$ & \\
\hline $\begin{array}{l}29 \\
\mathrm{KJa} \\
\mathrm{A}-6\end{array}$ & $\begin{array}{l}63^{\circ} 12^{\prime} 14^{\prime \prime} \\
149^{\circ} 45^{\prime} 57^{\prime \prime}\end{array}$ & $76-J-45$ & $\begin{array}{l}\text { Sandstone, } \\
\text { chert, and } \\
\text { limestone. }\end{array}$ & $\begin{array}{l}\text { Inoceramus sp. } \\
\text { Stratigraphically } 2 \mathrm{~m} \text { lower: } \\
\text { radiolarians. } \\
\text { Stratigraphically } 2 \mathrm{~m} \text { lower: } \\
\text { Buchia subiaevis. }\end{array}$ & $\begin{array}{l}\text { Early } \\
\text { Cretaceous } \\
\text { Earty } \\
\text { Cretaceous } \\
\text { (Valanginian) } \\
\quad \text { do. }\end{array}$ & $\begin{array}{l}\text { D.L Jones and } \\
\text { E.A. Pressagno in } \\
\text { Jones and others, } \\
1980 \text {. }\end{array}$ & \\
\hline $\begin{array}{l}30 \\
\mathrm{KJa} \\
\mathrm{A}-6\end{array}$ & $\begin{array}{l}63^{\circ} 12^{\prime} 18^{\prime \prime} \\
149^{\circ} 44^{\prime} 48^{\prime \prime}\end{array}$ & Unavailable & Limestone & Buchia subloevis. & do. & $\begin{array}{l}\text { D. L. Jones in } \\
\text { Jones and others, } \\
1980 \text {. }\end{array}$ & \\
\hline $\begin{array}{l}31 \\
\text { KJa } \\
\text { A-6 }\end{array}$ & $\begin{array}{l}63^{\circ} 13^{\prime} 06^{\prime \prime} \\
149^{\circ} 45^{\prime} 32^{\prime \prime}\end{array}$ & $\begin{array}{l}77-J-12 \\
77\lrcorner-13\end{array}$ & $\begin{array}{l}\text { Limestone } \\
\text { Chert. }\end{array}$ & $\begin{array}{l}\text { 77-J-12: Buchia sublaevis. } \\
\text { J1-J-13: Parvicinguia citae } \\
\text { and other radiolarians. }\end{array}$ & do. & do. & \\
\hline $\begin{array}{c}32 \\
\text { KJfI } \\
\text { B.6 }\end{array}$ & $\begin{array}{l}63^{\circ} 17^{\prime} 07^{\prime} \\
149^{\circ} 36^{\prime} 04^{\prime \prime}\end{array}$ & $F x-9$ & Argillite & Buchia sublaevis. & do. & $\begin{array}{l}\text { D.L. Jones in } \\
\text { Hawley and Clark, } \\
\text { 1974. }\end{array}$ & \\
\hline $\begin{array}{l}33 \\
\text { KJIt } \\
\text { B-5 }\end{array}$ & $\begin{array}{l}63^{\circ} 24^{\prime} 35^{\prime \prime} \\
149^{\circ} 02^{\prime} 15^{\prime \prime} \\
\text { (approx) }\end{array}$ & $77-J-6$ & do. & Buchia sublaevis. & do. & $\begin{array}{l}\text { D. L. Jones in } \\
\text { jones and others, } \\
1983 \text {. }\end{array}$ & \\
\hline $\begin{array}{l}34 \\
\text { KJfi } \\
\text { B-4 }\end{array}$ & $\begin{array}{l}63^{\circ} 24^{\prime} 15^{\circ} \\
148^{\circ} 54^{\prime} 40^{\circ}\end{array}$ & Unavailable & Unavailable & Ammonite & $\begin{array}{l}\text { Late } \\
\text { Cretaceous } \\
\text { (Cenomanian). }\end{array}$ & do. & \\
\hline $\begin{array}{l}35 \\
\text { KJil } \\
\text { B-4 }\end{array}$ & $\begin{array}{l}63^{\circ} 24^{\prime} 54^{\prime \prime} \\
148^{\circ} 53^{\prime} 49^{\prime \prime}\end{array}$ & $80-\sqrt{H}-38$ & do. & Calycoceras sp. (ammonite) & do. & do. & \\
\hline $\begin{array}{l}36 \\
\text { K.Jff } \\
\text { B-4 }\end{array}$ & $\begin{array}{l}63^{\circ} 25^{\prime} 47^{\prime \prime} \\
148^{\circ} 52^{\prime} 15^{\prime \prime}\end{array}$ & $\begin{array}{l}\text { U.W. 1553/09. CTW14, } \\
\text { Univ. of Wisconsin, } \\
\text { (same as USGS } \\
\text { Mesozoic locality } \\
\text { M5789); } 80 \text { AMM-26 }\end{array}$ & $\begin{array}{l}\text { Limestone } \\
\text { (shell hash) }\end{array}$ & $\begin{array}{l}\text { Inoceramus sp. } \\
\text { Acroteuthis? sp. (belemnite) } \\
\text { Indeterminate bivalve\{s) } \\
\text { Foraminifera }\end{array}$ & $\begin{array}{l}\text { Early } \\
\text { Cretaceous } \\
\text { (Hauteri- } \\
\text { ivian- } \\
\text { Barrernian). }\end{array}$ & $\begin{array}{l}\text { LR. Landon } \\
\text { (Univ. of Wiscon- } \\
\text { sin) in Sherwood } \\
\text { and Craddock, } \\
\text { 1979, D.L dones } \\
\text { in dones and oth- } \\
\text { ers, } 1980 \text {. }\end{array}$ & $\begin{array}{l}\text { The limestone bed at this } \\
\text { bcality is made almost en- } \\
\text { tirely of coarse Inoceramus, } \\
\text { indeterminate bivalve, and } \\
\text { belemnite fragments with a } \\
\text { few argillite and chert peb- } \\
\text { bles, all in finer grained } \\
\text { matrix of same material. }\end{array}$ \\
\hline
\end{tabular}


Table 2. Fossil data from the Healy quadrangle, Alaska-Continued

\begin{tabular}{|c|c|c|c|c|c|c|c|}
\hline $\begin{array}{l}\text { Map No., } \\
\text { map unit, } \\
\text { quad. No. }\end{array}$ & $\begin{array}{l}\text { Location } \\
\text { lat (N.) and } \\
\text { long (W.) }\end{array}$ & $\begin{array}{l}\text { Field No. (s), } \\
\text { (USGS Museum No.), } \\
\text { and (or) collector }\end{array}$ & Ltthology & Fossils & $\begin{array}{l}\text { Fossil } \\
\text { age }\end{array}$ & $\begin{array}{l}\text { Determiner } \\
\text { and (or) reference }\end{array}$ & Comments \\
\hline $\begin{array}{l}37 \\
\text { KJfl } \\
\text { B-6 }\end{array}$ & $\begin{array}{l}63^{\circ} 21^{\prime} 48^{\prime \prime} \\
149^{\circ} 38^{\prime} 43^{\prime \prime}\end{array}$ & $81-C C-75$ & $\begin{array}{l}\text { Limestone } \\
\text { clasts in } \\
\text { conglomerate. }\end{array}$ & $\begin{array}{l}\text { Conodonts: } \\
\text { Belodella devonica } \\
\text { Belodelia trianguiaris } \\
\text { Panderodus sp. } \\
\text { Bar and blade elements } \\
\text { Acotretid brachiopod }\end{array}$ & $\begin{array}{l}\text { Silurian } \\
\text { to Early } \\
\text { Devonian }\end{array}$ & $\begin{array}{l}\text { A.G. Haris, } \\
\text { written commun., } \\
1984 \text {. }\end{array}$ & $\begin{array}{l}\text { These limestone clasts may } \\
\text { have been derived from unit } \\
\text { DOs cropping out to the } \\
\text { north. CAl- } 4.5 \text { to } 5 \text {. }\end{array}$ \\
\hline $\begin{array}{l}38 \\
\text { KJf1 } \\
\text { B-6 }\end{array}$ & $\begin{array}{l}63^{\circ} 22^{\prime} 02^{\prime \prime} \\
149^{\circ} 31^{\prime} 00^{\prime \prime}\end{array}$ & $82-C C-53$ & do. & $\begin{array}{l}\text { Conodonts: } \\
\text { Panderodus sp. } \\
\text { Bar elements } \\
\text { Brachiopod tragments }\end{array}$ & $\begin{array}{l}\text { Middle } \\
\text { Ordovician } \\
\text { to Middle } \\
\text { Devonian. }\end{array}$ & do. & $\begin{array}{l}\text { These limestone clasts may } \\
\text { have been derived from unit } \\
\text { DOs cropping out to the } \\
\text { north. CAl-5.5 }\end{array}$ \\
\hline $\begin{array}{l}39 \\
\text { Kuf } \\
\text { C.5 }\end{array}$ & $\begin{array}{l}63^{\circ} 38^{\prime} 25^{\prime \prime} \\
149^{\circ} 29^{\prime} 50^{\prime \prime} \\
\text { (approx. loc.) }\end{array}$ & $\begin{array}{l}\text { W.G. Gilbert, } \\
\text { Ak DGGS }\end{array}$ & Argillite & Inoceramus cf. I. concentricus & $\begin{array}{l}\text { Mid- } \\
\text { Cretaceous. }\end{array}$ & $\begin{array}{l}\text { D.L. Jones in } \\
\text { Gilbert and } \\
\text { Redman, } 1977 .\end{array}$ & \\
\hline $\begin{array}{l}40 \\
\text { KJf } \\
\text { C-5 }\end{array}$ & $\begin{array}{l}63^{\circ} 33^{\prime} 33^{\prime \prime} \\
149^{\circ} 16^{\prime} 50^{\prime \prime}\end{array}$ & $80-\mathrm{JH}-32$ & Chert & Radiolarians & $\begin{array}{l}\text { Jurassic } \\
\text { or Creta- } \\
\text { ceous. }\end{array}$ & $\begin{array}{l}\text { D. L. dones in } \\
\text { Jones and others, } \\
1983 \text {. }\end{array}$ & \\
\hline $\begin{array}{l}41 \\
\text { Kuf } \\
\text { C-5 }\end{array}$ & $\begin{array}{l}63^{\circ} 30^{\circ} 30^{\circ} \\
149^{\circ} 23^{\prime} 49^{\prime \prime}\end{array}$ & $\begin{array}{l}80-\sqrt{H}-18 \\
\text { (MR-2043); } \\
\text { 80-JH-19, } \\
\text { (MR-2044) }\end{array}$ & do. & Radiolarians & do. & do. & \\
\hline $\begin{array}{l}42 \\
\text { KJf } \\
\text { C-5 }\end{array}$ & $\begin{array}{l}63^{\circ} 30^{\prime} 35^{\circ} \\
149^{\circ} 12^{\prime} 20^{\prime \prime} \\
\text { (approx. loc.) }\end{array}$ & $\begin{array}{l}\text { 80-JH-33A, } \\
\text { (MR-2046) }\end{array}$ & do. & Radiolarians & do. & do. & \\
\hline $\begin{array}{l}43 \\
\mathrm{~ms} \mid \\
\mathrm{B}-4\end{array}$ & $\begin{array}{l}63^{\circ} 27^{\prime} 14^{\prime \prime} \\
148^{\circ} 39^{\prime} 35^{\prime \prime}\end{array}$ & $\begin{array}{l}\text { U.W. } 1574 / 02 \text {, } \\
\text { CTW 88, } \\
\text { Univ. of Wisconsin }\end{array}$ & Limestone & $\begin{array}{l}\text { Solitary corals } \\
\text { Bryozoans }\end{array}$ & Paleozoic & $\begin{array}{l}\text { L.R. Landon in } \\
\text { Sherwood and } \\
\text { Craddock, } 1979 .\end{array}$ & $\begin{array}{l}\text { Fault block?? in melange } \\
\text { of Cretaceous age. }\end{array}$ \\
\hline $\begin{array}{c}44 \\
\text { Kms } \\
\text { B-4 }\end{array}$ & $\begin{array}{l}63^{\circ} 25^{\prime} 57^{\prime \prime} \\
148^{\circ} 40^{\prime} 54^{\prime \prime}\end{array}$ & $\begin{array}{l}\text { U.W. } 1633 / 40 \text {, } \\
\text { CTW } 56 \text {, } \\
\text { Univ. of Wisconsin }\end{array}$ & Argillite & $\begin{array}{l}\text { Conodonts fragment: } \\
\text { Platiorm blade of Palmatolepis? sp. }\end{array}$ & $\begin{array}{l}\text { Ordovician } \\
\text { to Trias. } \\
\text { sic; Late } \\
\text { Devoniant? }\end{array}$ & $\begin{array}{l}\text { D.L. Clark in } \\
\text { Sherwood and } \\
\text { Craddock, } 1979 . \\
\text { M.W. Mullen, } \\
\text { this report. }\end{array}$ & $\begin{array}{l}\text { Fault biocki?) in melange } \\
\text { of Cretaceous age. Fragment } \\
\text { examined with SEM. CAL- } 6 \text {. }\end{array}$ \\
\hline $\begin{array}{c}45 \\
\mathrm{Kms} \\
\mathrm{B}-4\end{array}$ & $\begin{array}{l}63^{\circ} 25^{\prime} 10^{*} \\
148^{\circ} 43^{\prime} 25^{\prime \prime}\end{array}$ & $81 \mathrm{AC} y-48 \mathrm{a}$ & Chert & $\begin{array}{l}\text { Radiolarians: } \\
\text { Parasatumalidae fragment, inde- } \\
\text { terminate Spumellarians }\end{array}$ & $\begin{array}{l}\text { Late } \\
\text { Triassic } \\
\text { to Late }\end{array}$ & $\begin{array}{l}\text { N.R.D. Albert, } \\
\text { witten commun., } \\
1982 \text {. }\end{array}$ & $\begin{array}{l}\text { Possible contamination } \\
\text { during sample processing. }\end{array}$ \\
\hline $\begin{array}{l}46 \\
\text { ms! } \\
\text { B-4 }\end{array}$ & $\begin{array}{l}63^{\circ} 23^{\prime} 47^{\prime \prime} \\
148^{\circ} 44^{\prime} 25^{\prime \prime}\end{array}$ & $\begin{array}{l}\text { U.W. } 1553 / 10 \text {, } \\
\text { CTW 139, } \\
\text { Univ. of Wisconsin }\end{array}$ & Limestone & $\begin{array}{l}\text { Gastropods, crinoid tragments. } \\
\text { bryozoans, corals, } \\
\text { Astroeospongia sp. spicules }\end{array}$ & $\begin{array}{l}\text { Cretaceous. } \\
\text { Siluriant? }\end{array}$ & $\begin{array}{l}\text { L.R. Landon and } \\
\text { J.K. Rigby in } \\
\text { Sherwood and } \\
\text { Craddock, } 1979 .\end{array}$ & $\begin{array}{l}\text { Fault block or slide block } \\
\text { (olisthostrome) in melange } \\
\text { of Cretaceous age. }\end{array}$ \\
\hline
\end{tabular}




$\begin{array}{lll}47 & 63^{\circ} 23^{\prime} 03^{*} & \text { A-713; } \\ \text { msl } & 148^{\circ} 52^{\prime} 53^{\prime \prime} & \text { Univ. of Alaska Mus: } \\ \text { B-4 } & & 76-285, \\ & & \text { (USGS 9709-SD): } \\ & & \end{array}$

83 AMM-1D

$\begin{array}{cll}48 & 63^{\circ} 23^{\prime} 45^{\prime \prime} & 77-\mathrm{J}-3 \\ \text { Kms } & 148^{\circ} 55^{\prime} 20^{\prime \prime} & \\ \text { B-4 } & \text { (approx. loc) } & \\ 49 & 63^{\circ} 22^{\prime} 32^{\prime \prime} & 77-J-5 \\ \text { Kms } & 148^{\circ} 57^{\prime} 30^{\prime \prime} & \\ \text { B-4 } & & \\ 50 & 63^{\circ} 10^{\prime} 24^{\prime \prime} & 77-J-7 \\ \text { Kms } & 149^{\circ} 31^{\circ} 04^{\prime \prime} & \\ \text { A-6 } & & \end{array}$

do

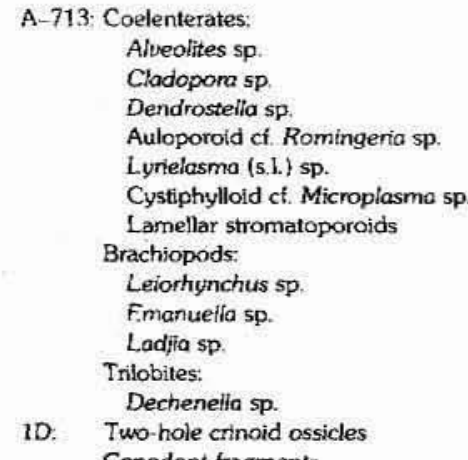

$149^{\circ} 33^{\prime} 51^{\circ}$

$63^{\circ} 06^{\prime} 51^{\prime \prime}$

$149^{\circ} 37^{\circ} 03^{*}$

$75 \mathrm{ANw}-75$

(9743-SD)

$63^{\circ} 06^{\prime} 27^{\prime \prime}$

$149^{\circ} 36^{\prime} 40^{\prime \prime}$

$75 \mathrm{ANw}-76$,

(9744 SD)

$63^{\circ} 03^{\prime} 45^{\prime \prime}$

$149^{\circ} 41^{\prime} 55^{\prime \prime}$

75 ANw-82,

(9824-SD]

$63^{\circ} 27^{\prime} 36^{\circ}$

$148^{\circ} 46^{\prime} 30^{\prime \prime}$

82-DP-3-1/2,

(10862-SD)

B-4

\section{Radiolarian}

do.

do

do.

do

Middle

Devonian

(Givetian)

W.A. Oliver,

writen commun

Millen, this

report.

Carboni-

ferous.

B. K. Holdsworth in jones and others

1980.

do.

do.

do.

Late Pal-

eozocic, Late

Devonian or

younger.

do.

do.

Silurian W.A. Oliver,

$\begin{array}{lll}\begin{array}{l}\text { Silurian } \\ \text { and Devon- }\end{array} & \begin{array}{l}\text { W.A. Oliver, } \\ \text { written commun., }\end{array} & \begin{array}{l}\text { Fault block or slide block } \\ \text { (olisthostrome) in melange }\end{array}\end{array}$

Dendrostella? sp.
Massive stromatoporoid

do. Labechio sp

Labechia sp
Favosites sp

co.

Conodonts

do.

Conodonts:

Polygnathus cf. $P$, uarus

(Stauffer group)

Indeteminate bar and blade

elements

do.

Sagenites?

Indeterminate clams and

belemnites an, Middle 1977.

Siturian

Sturian

or Devon-
lan.

Late

Silurian

Silunian

or Early

Late Mid-

die Devon-

ian

(olisthostrome) in melange of Cretaceous age.

Do.

A.G. Harris in From isolated exposures of Jones and others, limestone associated with 1980 serpentinite in melange of Cretaceous age.

AG. Harris,

written commun.,

1984.

Fault block or stide block

(olisthastrome) in melange

(Givetian)

of Cretaceous age. CAl-5.

Late

L.R. Laudon in

Sherwood and

Craddock, 1979.
Fault black or slide block (olisthostrome) in Cretaceous melange. 
Table 2. Fossil data from the Healy quadrangle, Alaska-Continued

\begin{tabular}{|c|c|c|c|c|c|c|c|}
\hline $\begin{array}{l}\text { Map No., } \\
\text { map unit, } \\
\text { quad. No. }\end{array}$ & $\begin{array}{l}\text { Location } \\
\text { lat (N.) and } \\
\text { long (W.) }\end{array}$ & $\begin{array}{l}\text { Field No. (5), } \\
\text { (USGS Museum No.). } \\
\text { and (or) collector }\end{array}$ & Lithology & Fossils & $\begin{array}{l}\text { Fossil } \\
\text { age }\end{array}$ & $\begin{array}{l}\text { Determiner } \\
\text { and (or) reference }\end{array}$ & Comments \\
\hline $\begin{array}{l}57 \\
\mathrm{~K} m \mathrm{n} \\
\mathrm{B}-4\end{array}$ & $\begin{array}{l}63^{\circ} 27^{\prime} 19^{\prime \prime} \\
148^{\circ} 55^{\prime} 26^{\prime \prime}\end{array}$ & $80-\sqrt{M}-34$ & $\begin{array}{l}\text { Chert clasts } \\
\text { in conglomer- } \\
\text { ate. }\end{array}$ & Radiolarians & $\begin{array}{l}\text { Jurassic } \\
\text { and Mis- } \\
\text { sissippian. }\end{array}$ & $\begin{array}{l}\text { D.L. Jones in } \\
\text { Jones and others, } \\
1983 .\end{array}$ & \\
\hline $\begin{array}{c}58 \\
\text { Kmn } \\
B-4\end{array}$ & $\begin{array}{l}63^{\circ} 27^{\prime} 25^{\prime \prime} \\
148^{\circ} 566^{\prime} 50^{\prime} \\
\text { (approx loc) }\end{array}$ & Unavailable & Argillite & Buchia sp. & $\begin{array}{l}\text { Late Jur- } \\
\text { assic to } \\
\text { Late Cre- } \\
\text { taceous. }\end{array}$ & $\begin{array}{l}\text { D.L. Jones, } \\
\text { oral commun., } \\
1985 \text {. }\end{array}$ & $\begin{array}{l}\text { Equivalent of unit KJfl } \\
\text { in Cretaceous melange, }\end{array}$ \\
\hline $\begin{array}{l}59 \\
\mathrm{mni} \\
\mathrm{B}-4\end{array}$ & $\begin{array}{l}63^{\circ} 26^{\prime} 42^{\prime \prime} \\
148^{\circ} 55^{\prime} 40^{\prime \prime}\end{array}$ & $\begin{array}{l}\text { 47-ACb-76 } \\
\text { U.W. } 1633 / 24 \\
\text { Univ. of Wisconsin }\end{array}$ & Limestone & $\begin{array}{l}\text { Tryplasma sp. } \\
\text { Lyriedasma? sp. } \\
\text { Zelophylium? sp. } \\
\text { Clavidictyon sp. } \\
\text { Amphipora sp. }\end{array}$ & $\begin{array}{l}\text { Middle } \\
\text { Devonian. }\end{array}$ & $\begin{array}{l}\text { J.M. Berdan in } \\
\text { Moxham and others, } \\
\text { 1959; W.A. Oliver } \\
\text { in Sherwood and } \\
\text { Craddock, } 1979 .\end{array}$ & $\begin{array}{l}\text { Fault block or stide block } \\
\text { (olisthostrome) in Creta- } \\
\text { ceous melange. }\end{array}$ \\
\hline $\begin{array}{l}60 \\
\mathrm{mnl} \\
\mathrm{B}-4\end{array}$ & $\begin{array}{l}63^{\circ} 27^{\prime} 24^{\prime \prime} \\
148^{\circ} 57^{\prime} 18^{\prime \prime}\end{array}$ & $\begin{array}{l}47-A C b-78 \\
47-A C b-79\end{array}$ & da. & $\begin{array}{l}\text { 78: Megalodius sp. } \\
\text { Mysidia sp. } \\
\text { 79: Belemnite sp. indeterminate }\end{array}$ & $\begin{array}{l}\text { Late } \\
\text { Triassic. }\end{array}$ & $\begin{array}{l}\text { R.M. Imlay in } \\
\text { Moxharm and } \\
\text { others, } 1959 \text {. }\end{array}$ & Do. \\
\hline $\begin{array}{l}61 \\
\mathrm{mnl} \\
\mathrm{B}-5\end{array}$ & $\begin{array}{l}63^{\circ} 26^{\prime} 55^{\circ} \\
149^{\circ} 02^{\prime} 00^{\prime \prime}\end{array}$ & $\begin{array}{l}\text { 50-AMx-101 } \\
\text { to } 105\end{array}$ & do. & $\begin{array}{l}\text { Cladopora sp. } \\
\text { Coenites? sp. } \\
\text { Pseudamplexoid coral } \\
\text { Unidentified hom coral } \\
\text { Stromatoporoids } \\
\text { Unidentified bryozoan }\end{array}$ & $\begin{array}{l}\text { Middle } \\
\text { Devonian. }\end{array}$ & $\begin{array}{l}\text { J.M. Berdan in } \\
\text { Moxham and others, } \\
1959 \text {. }\end{array}$ & Do. \\
\hline $\begin{array}{l}62 \\
\mathrm{mnl} \\
\mathrm{B}-5\end{array}$ & $\begin{array}{l}63^{\circ} 25^{\prime} 05^{\prime \prime} \\
149^{\circ} 15^{\prime} 15^{\prime \prime}\end{array}$ & $80-5-494$ & do & Molluses, brachiopods, conodonts & $\begin{array}{l}\text { Ordovician } \\
\text { or Devon- } \\
\text { tan. }\end{array}$ & $\begin{array}{l}\text { EL. Yochelson } \\
\text { and J.T. Dutro in } \\
\text { Jones and others, } \\
1983 .\end{array}$ & Do. \\
\hline $\begin{array}{l}63 \\
\text { mnl } \\
\text { B-5 }\end{array}$ & $\begin{array}{l}63^{\circ} 24^{\prime} 59^{\prime \prime} \\
149^{\circ} 16^{\prime} 37^{\prime \prime}\end{array}$ & $\begin{array}{l}\text { U.W. 1574/20, } \\
\text { FP } 107 \text {, } \\
\text { Univ. of Wisconsin; } \\
\text { 80-S-495, } \\
\text { (USGS 10099-SD) }\end{array}$ & do. & Crinoid fragments, corals & Devonian & $\begin{array}{l}\text { Thomas DeKeyser in } \\
\text { Sherwood and Crad- } \\
\text { dock, 1979; W.A. } \\
\text { Oliver in Jones } \\
\text { and others, } 1983 \text {. }\end{array}$ & Do. \\
\hline $\begin{array}{l}64 \\
\text { Jhta } \\
\text { A-6 }\end{array}$ & $\begin{array}{l}63^{\circ} 01^{\prime} 23^{\prime \prime} \\
149^{\circ} 53^{\prime} 04^{\prime \prime}\end{array}$ & $\begin{array}{l}\text { 76-SP-322, } \\
\text { (USGS Mesozoic } \\
\text { ioc. } 31262 \text { ) }\end{array}$ & $\begin{array}{l}\text { Sandy lime- } \\
\text { stone and cal- } \\
\text { careous sand- } \\
\text { stone. }\end{array}$ & $\begin{array}{l}\text { Arnioceras cf. } A \text { densicosta } \\
\text { Pleuromya sp. }\end{array}$ & $\begin{array}{l}\text { Early } \\
\text { jurassic } \\
\text { (early } \\
\text { Sinemurian). }\end{array}$ & $\begin{array}{l}\text { R.W. Imlay, } \\
\text { written commun. } \\
1976 \text {. }\end{array}$ & \\
\hline $\begin{array}{l}65 \\
\text { J Jita } \\
\text { A-6 }\end{array}$ & $\begin{array}{l}63^{\circ} 02^{\prime} 23^{\prime \prime} \\
149^{\circ} 51^{\prime} 47^{\prime \prime}\end{array}$ & $\begin{array}{l}\text { 76-5-332, } \\
\text { (USGS Mesozoic } \\
\text { loc. } 31265 \text { ) }\end{array}$ & do. & $\begin{array}{l}\text { Amioceras(?) sp. } \\
\text { Psiloceros? canadense } \\
\text { Belemnite fragment } \\
\text { Pleuromya sp. }\end{array}$ & do & 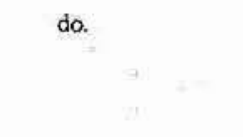 & \\
\hline $\begin{array}{l}66 \\
\text { Jkta } \\
\text { A-6 }\end{array}$ & $\begin{array}{l}63^{\circ} 02^{\prime} 48^{\prime \prime} \\
149^{\circ} 51^{\prime \prime} 21^{\prime \prime}\end{array}$ & $\begin{array}{l}\text { 76-SP-3331, } \\
\text { (USGS Mesozoic } \\
\text { loc. } 31264 \text { ) }\end{array}$ & do. & $\begin{array}{l}\text { Arietitid ammonite. } \\
\text { Psilocerus? canadense }\end{array}$ & do. & do. & \\
\hline
\end{tabular}




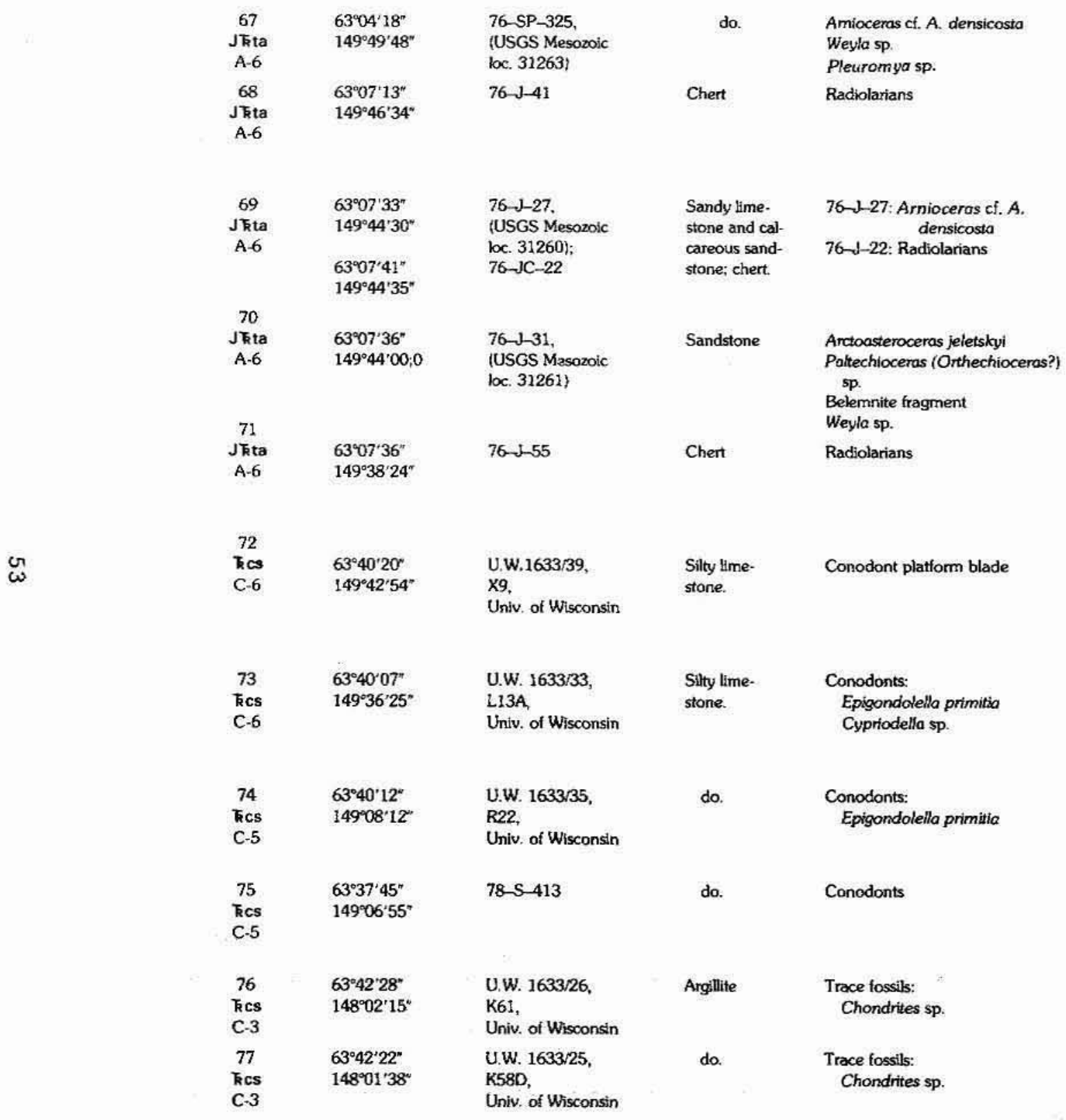

do.

do.

\begin{tabular}{|c|c|c|}
\hline $\begin{array}{l}\text { Late Jur- } \\
\text { assic (Cal- } \\
\text { lovian to } \\
\text { earty } \\
\text { Tithonian). }\end{array}$ & $\begin{array}{l}\text { C.D. Blome in } \\
\text { Jones and others, } \\
1980 \text {. }\end{array}$ & \\
\hline $\begin{array}{l}\text { Early Jur- } \\
\text { assic } \\
\text { (early } \\
\text { Sinemur- } \\
\text { iani; Late } \\
\text { Jurassic. }\end{array}$ & $\begin{array}{l}\text { R.W. Imlay, } \\
\text { written commun., } \\
\text { 1976; C.D. Blome } \\
\text { in Jones and } \\
\text { others, } 1980 \text {. }\end{array}$ & \\
\hline $\begin{array}{l}\text { Early Jur- } \\
\text { assic } \\
\text { flate } \\
\text { Sinemur- } \\
\text { ian). }\end{array}$ & $\begin{array}{l}\text { R.W. Imlay, } \\
\text { written commun., } \\
\text { 1976; Jones and } \\
\text { others, } 1980 \text {. }\end{array}$ & $\begin{array}{l}\text { Sandstone interbedded } \\
\text { with massive crystal tuft }\end{array}$ \\
\hline $\begin{array}{l}\text { Late } \\
\text { Jurassic. } \\
\text { ICallovian } \\
\text { to early } \\
\text { Tithonian }\end{array}$ & $\begin{array}{l}\text { C.D. Blome in } \\
\text { Jones and others, } \\
1980 \text {. }\end{array}$ & \\
\hline Triassic\{?\}] & $\begin{array}{l}\text { D.L. Clark in } \\
\text { Sherwood and } \\
\text { Craddock, 1979, } \\
\text { M.M. Mullen, } \\
\text { this report. }\end{array}$ & CAl-6 \\
\hline $\begin{array}{l}\text { Late } \\
\text { Triassic } \\
\text { (early } \\
\text { Norian). }\end{array}$ & $\begin{array}{l}\text { D.L. Clark in } \\
\text { Shenwood and } \\
\text { Craddock, 1979; } \\
\text { M.W. Mullen, } \\
\text { this report }\end{array}$ & $\begin{array}{l}\text { Conodont specimens were } \\
\text { reexamined and photo- } \\
\text { graphed with the SEM. } \\
\text { CAI-6. }\end{array}$ \\
\hline do. & do. & $\begin{array}{l}\text { Conodiont specimens were } \\
\text { reexamined and photo- } \\
\text { graphed with the SEM. } \\
\text { CAI- } 5.5 \text { to } 6 \text {. }\end{array}$ \\
\hline $\begin{array}{l}\text { Late } \\
\text { Triassic } \\
\text { (Kamian } \\
\text { to Norian). }\end{array}$ & $\begin{array}{l}\text { B.R. Warlaw in } \\
\text { Jones and others, } \\
1983 \text {. }\end{array}$ & \\
\hline Triassic & $\begin{array}{l}\text { N.J. Siberling } \\
\text { in Sherwood and } \\
\text { Craddock, } 1979 .\end{array}$ & $\begin{array}{l}\text { Previously identified as } \\
\text { possible graptolites. }\end{array}$ \\
\hline
\end{tabular}

do.

do.

Do. 
Table 2. Fassil data from the Healy quadrangle, Alaska-Continued

\begin{tabular}{|c|c|c|c|c|c|c|c|}
\hline $\begin{array}{l}\text { Map No., } \\
\text { map unit, } \\
\text { quad. No. }\end{array}$ & $\begin{array}{l}\text { Location } \\
\text { lat (N.) and } \\
\text { long (W.) }\end{array}$ & $\begin{array}{l}\text { Field No. (s). } \\
\text { fUSGS Museum No.), } \\
\text { and (or) collector }\end{array}$ & Lithology & Fossils & $\begin{array}{l}\text { Fossil } \\
\text { age }\end{array}$ & $\begin{array}{l}\text { Determiner } \\
\text { and (or) reference }\end{array}$ & Cornments \\
\hline $\begin{array}{l}78 \\
\text { Kcs } \\
\text { C-2 }\end{array}$ & $\begin{array}{l}63^{\circ} 43^{\prime} 10^{\prime \prime} \\
147^{\circ} 56^{\prime} 20^{\prime \prime}\end{array}$ & $\begin{array}{l}\text { U.W. } 1580 / 53 \text {, } \\
\text { RLA } 156, \\
\text { Univ. of Wisconsin }\end{array}$ & do. & $\begin{array}{l}\text { Trace fossils: } \\
\text { Chondintes sp. }\end{array}$ & do. & do. & Do. \\
\hline $\begin{array}{l}79 \\
\text { Kcs } \\
\text { C-2 }\end{array}$ & $\begin{array}{l}63^{\circ} 41^{\prime} 26^{\prime \prime} \\
147^{\circ} 50^{\prime} 15^{\prime \prime}\end{array}$ & $\begin{array}{l}\text { U.W. } 1633 / 30 \text {, } \\
\text { TC } 357 \mathrm{~A}, \mathrm{D}, \mathrm{E}, \mathrm{G} \text {; } \\
\text { U.W. 1622/31, } \\
\text { TC } 357 \mathrm{~B} \\
\text { Univ. of Wisconsin }\end{array}$ & do. & $\begin{array}{l}\text { Trace fossils: } \\
\text { Chondrites sp. }\end{array}$ & do. & do. & Do. \\
\hline $\begin{array}{l}80 \\
\text { Kcs } \\
\text { C-2 }\end{array}$ & $\begin{array}{l}63^{\circ} 41^{\prime} 32^{\prime \prime} \\
147^{\circ} 48^{\prime} 48^{\prime \prime} \\
63^{\circ} 41^{\prime} 46^{\prime \prime} \\
147^{\circ} 49^{\circ} 00^{\prime \prime}\end{array}$ & $\begin{array}{l}\text { U.W. 1633/28, } \\
\text { TC } 265 \text {; } \\
\text { U.W. 1633/29. } \\
\text { TC 328A, B, C, E, F, G } \\
\text { Univ. of Wisconsin }\end{array}$ & do. & $\begin{array}{l}\text { Trace fossits: } \\
\text { Chondrites sp. } \\
\text { Helminthoida sp. } \\
\text { Phycosiphon sp. }\end{array}$ & do. & $\begin{array}{l}\text { N.J. Silberling } \\
\text { and C.K Chamber- } \\
\text { lain in Sherwood } \\
\text { and Craddock, } 1979 .\end{array}$ & Do. \\
\hline $\begin{array}{l}81 \\
\text { kcs } \\
\text { C-2 }\end{array}$ & $\begin{array}{l}63^{\circ} 42^{\prime} 48^{\prime \prime} \\
147^{\circ} 46^{\prime} 52^{\prime \prime}\end{array}$ & $\begin{array}{l}\text { U.W. 1633/47, } \\
\text { K450, } \\
\text { Univ. of Wisconsin }\end{array}$ & do. & $\begin{array}{l}\text { Trace fossils: } \\
\text { Chondrites sp. }\end{array}$ & Triassic(?) & do. & Do \\
\hline $\begin{array}{l}82 \\
\text { kcs } \\
\text { C-2 }\end{array}$ & $\begin{array}{l}63^{\circ} 44^{\prime} 14^{\circ} \\
147^{\circ} 49^{\prime} 14^{\prime \prime}\end{array}$ & 83 AMM-13 & $\begin{array}{l}\text { Silty lime- } \\
\text { stone. }\end{array}$ & $\begin{array}{l}\text { Conodonts: } \\
\text { Neogondolella polygnathiformis } \\
\text { Epigondolella primitia } \\
\text { Cypriodella? sp. }\end{array}$ & $\begin{array}{l}\text { Late } \\
\text { Triassic } \\
\text { (late Kar- } \\
\text { nian to early } \\
\text { Norian). }\end{array}$ & $\begin{array}{l}\text { MW. Mulier, } \\
\text { this report. }\end{array}$ & CAl-5 to 6 \\
\hline $\begin{array}{l}83 \\
\text { रcs } \\
\text { C-2 }\end{array}$ & $\begin{array}{l}63^{\circ} 44^{\prime} 46^{\prime \prime} \\
147^{\circ} 38^{\prime} 55^{\prime \prime}\end{array}$ & $\begin{array}{l}1633 / 37 \\
\text { K230, } \\
\text { Univ. of Wisconsin }\end{array}$ & do. & $\begin{array}{l}\text { Conodonts: } \\
\text { Neogondolella polygnathiformis } \\
\text { Neogondolella sp. } \\
\text { Epigondolella primitio? }\end{array}$ & do. & $\begin{array}{l}\text { D.L. Clark in } \\
\text { Sherwood and } \\
\text { Craddock, } 1979 \text {; } \\
\text { M.W. Mullen, } \\
\text { this report. }\end{array}$ & $\begin{array}{l}\text { Specimens were reexam- } \\
\text { ined and photographed with } \\
\text { the SEM. CAl-6. }\end{array}$ \\
\hline $\begin{array}{l}84 \\
\text { KCs } \\
\text { C-2 }\end{array}$ & $\begin{array}{l}63^{\circ} 44^{\prime} 57^{\prime \prime} \\
147^{\circ} 37^{\prime} 12^{\prime \prime}\end{array}$ & $81 \mathrm{AC}_{y-18}$ & $\begin{array}{l}\text { Silty lime- } \\
\text { stone. }\end{array}$ & $\begin{array}{l}\text { Conodonts } \\
\text { Neogondolella cf. N. tadpole } \\
\text { Epigondolella primitia }\end{array}$ & do. & $\begin{array}{l}\text { M.W. Mulen, } \\
\text { This report. }\end{array}$ & $\mathrm{CAI}-6$ \\
\hline $\begin{array}{l}85 \\
\text { K } \mathrm{cs} \\
\mathrm{C}-2\end{array}$ & $\begin{array}{l}63^{\circ} 44^{\prime} 16^{\prime \prime} \\
147^{\circ} 37^{\prime} 25^{\prime \prime}\end{array}$ & $\begin{array}{l}\text { U.W. } 1633 / 31 \text {, } \\
\text { K } 212 \text {. } \\
\text { Univ. of Wisconsin }\end{array}$ & Argillite & $\begin{array}{l}\text { Trace fossils: } \\
\text { Chondrites? sp. }\end{array}$ & $\begin{array}{l}\text { Trias- } \\
\text { sic(?). }\end{array}$ & $\begin{array}{l}\text { N.J. Sibering } \\
\text { in Sherwood and } \\
\text { Craddock, } 1979 .\end{array}$ & $\begin{array}{l}\text { Previously identified as } \\
\text { possible graptolites. }\end{array}$ \\
\hline $\begin{array}{l}86 \\
\text { Rcs } \\
\text { C-2 }\end{array}$ & $\begin{array}{l}63^{\circ} 44^{\prime} 18^{\prime \prime} \\
147^{\circ} 36^{\prime} 40^{\prime \prime}\end{array}$ & $\begin{array}{l}\text { U.W. } 1633 / 27 \\
\text { K } 214 \text {, } \\
\text { Univ. of Wisconsin }\end{array}$ & do. & $\begin{array}{l}\text { Trace fossils: } \\
\text { Chondrites? sp. }\end{array}$ & do. & do. & Do. \\
\hline $\begin{array}{l}87 \\
\text { Kcs } \\
\text { C. } 2\end{array}$ & $\begin{array}{l}63^{\circ} 43^{\prime} 47^{\prime \prime} \\
147^{\circ} 36^{\prime} 05^{\prime \prime}\end{array}$ & $\begin{array}{l}\text { U.W. } 1633 / 36 \text {, } \\
\text { K } 285 B \text {. } \\
\text { Univ. of Wisconsin }\end{array}$ & $\begin{array}{l}\text { Silty lime- } \\
\text { stone. }\end{array}$ & $\begin{array}{l}\text { Conodonts: } \\
\text { Epigondolella primitia? }\end{array}$ & $\begin{array}{l}\text { Late } \\
\text { Triassic } \\
\text { (early } \\
\text { Norian). }\end{array}$ & $\begin{array}{l}\text { D.L. Clark in } \\
\text { Sherwood and } \\
\text { Craddock, 1979; } \\
\text { M.W. Mullen, } \\
\text { this report. }\end{array}$ & CAI-6. \\
\hline
\end{tabular}




\begin{tabular}{|c|c|c|c|c|c|c|c|}
\hline $\begin{array}{l}88 \\
\text { kcs } \\
\text { C-2 }\end{array}$ & $\begin{array}{l}63^{\circ} 44^{\prime} 12^{\prime \prime} \\
147^{\circ} 34^{\prime} 14^{\prime \prime}\end{array}$ & 83 AMM-11 & do. & Conodont fragments & $\begin{array}{l}\text { Ordovician } \\
\text { to } \\
\text { Triassic. }\end{array}$ & $\begin{array}{l}\text { M.W. Mullen, } \\
\text { this report, }\end{array}$ & Do. \\
\hline $\begin{array}{l}89 \\
\text { Kcs } \\
\text { D-2 }\end{array}$ & $\begin{array}{l}63^{\circ} 44^{\prime} 48^{\prime \prime} \\
147^{\circ} 31^{\prime} 10^{\prime \prime}\end{array}$ & $\begin{array}{l}\text { U.W. } 1633 / 34 \text {, } \\
\text { K } 466 \text {, } \\
\text { Univ. of Wisconsin }\end{array}$ & do. & $\begin{array}{l}\text { Conodonts: } \\
\text { Epigondolellia sp. }\end{array}$ & $\begin{array}{l}\text { Late } \\
\text { Triassic } \\
\text { (Karnian } \\
\text { to Norian). }\end{array}$ & $\begin{array}{l}\text { D.L. Clark in } \\
\text { Sherwood and } \\
\text { Craddock, } 1979 \text {, } \\
\text { M.W. Mullen, } \\
\text { this report. }\end{array}$ & $\begin{array}{l}\text { Specimens were reexamined } \\
\text { and photographed with the } \\
\text { SEM CAl-5.5 to } 6 \text {. }\end{array}$ \\
\hline $\begin{array}{l}90 \\
\text { Kcs } \\
\text { C-3 }\end{array}$ & $\begin{array}{l}63^{\circ} 32^{\prime} 58^{\prime \prime} \\
148^{\circ} 05^{\prime} 05^{\prime \prime}\end{array}$ & 83 AMM-9 & do. & $\begin{array}{l}\text { Conodonts: } \\
\text { Neogondolella poiygnathiformis } \\
\text { Neogondolella sp. } \\
\text { Epigondolella primitia } \\
\text { Cypriodella sp. }\end{array}$ & $\begin{array}{l}\text { Late } \\
\text { Triassic } \\
\text { (late } \\
\text { Karnian to } \\
\text { early } \\
\text { Norian). }\end{array}$ & $\begin{array}{l}\text { M.W. Mullen, } \\
\text { this report. }\end{array}$ & CAl-5.5 to 6 . \\
\hline $\begin{array}{l}91 \\
\text { Kcs } \\
\text { C-2 }\end{array}$ & $\begin{array}{l}63^{\circ} 32^{\prime} 50^{\prime \prime} \\
147^{\circ} 59^{\prime} 10^{\prime \prime}\end{array}$ & $\begin{array}{l}\text { U.W. 1622/23, } \\
\text { TC } 231 \mathrm{~B} \text {, } \\
\text { Univ. of Wisconsin }\end{array}$ & do. & $\begin{array}{l}\text { Conodonts: } \\
\text { Epigondolella primitia? }\end{array}$ & $\begin{array}{l}\text { Late } \\
\text { Triassic } \\
\text { (early } \\
\text { Norian). }\end{array}$ & $\begin{array}{l}\text { D.L. Clark in } \\
\text { Sherwood and } \\
\text { Craddock, 1979; } \\
\text { M.W. Mullen, } \\
\text { this report. }\end{array}$ & $\begin{array}{l}\text { Specimens were reexamined } \\
\text { and photographed with the } \\
\text { SEM. CAl-6. }\end{array}$ \\
\hline $\begin{array}{l}92 \\
\text { Kes } \\
\text { C-3 }\end{array}$ & $\begin{array}{l}63^{\circ} 36^{\prime} 10^{\prime \prime} \\
147^{\circ} 31^{\prime} 55^{\prime \prime}\end{array}$ & $\begin{array}{l}\text { Unavailable, } \\
\text { W.M. Brewer, } \\
\text { Univ. of Wisconsin }\end{array}$ & do. & $\begin{array}{l}\text { Conodonts: } \\
\text { Epigondolella abneptis }\end{array}$ & $\begin{array}{l}\text { Late } \\
\text { Triassic } \\
\text { (Norian). }\end{array}$ & $\begin{array}{l}\text { D. L. Clark in } \\
\text { Brewer, } 1982 .\end{array}$ & \\
\hline $\begin{array}{l}93 \\
\mathrm{kes} \\
\mathrm{B}-3\end{array}$ & $\begin{array}{l}63^{\circ} 25^{\circ} 07^{\prime \prime} \\
148^{\circ} 06^{\prime} 14^{\prime \prime}\end{array}$ & 81 ACy-82 & $\begin{array}{l}\text { Sandy lime- } \\
\text { stone. }\end{array}$ & $\begin{array}{l}\text { Conodonts: } \\
\text { Neogondolella polygnathiformis? } \\
\text { Epigondolella primitia } \\
\text { Mollusc: } \\
\text { Monotis cl. M. subcircularis }\end{array}$ & $\begin{array}{l}\text { Late } \\
\text { Triassic } \\
\text { (late } \\
\text { Kamian } \\
\text { to early } \\
\text { Norian): } \\
\text { Norian. }\end{array}$ & $\begin{array}{l}\text { M.W. Mullen, } \\
\text { this report, } \\
\text { N.J. Silberling, } \\
\text { written commun, } \\
1982 \text {. }\end{array}$ & Shelf deposits. CAl-5. \\
\hline $\begin{array}{l}94 \\
\text { KCs } \\
\text { B-3 }\end{array}$ & $\begin{array}{l}63^{\circ} 25^{\prime} 58^{\prime \prime} \\
148^{\circ} 05^{\prime} 42^{\prime \prime}\end{array}$ & 79 ASf-3 & do. & $\begin{array}{l}\text { Conodonts: } \\
\text { Neogondolella polygnathijormis } \\
\text { Epigondolella primitia } \\
\text { Cypriodella sp. }\end{array}$ & $\begin{array}{l}\text { Late Tri- } \\
\text { assic } \\
\text { (late Kar- } \\
\text { nian to early } \\
\text { Norian). }\end{array}$ & $\begin{array}{l}\text { M.W. Mullen, } \\
\text { this report. }\end{array}$ & Shelf deposits. CAI-5 \\
\hline $\begin{array}{l}95 \\
\text { Kcs } \\
\text { B-3 }\end{array}$ & $\begin{array}{l}63^{\circ} 27^{\prime} 03^{\prime \prime} \\
148^{\circ} 01^{\prime \prime} 26^{\prime \prime}\end{array}$ & $\begin{array}{l}\text { U.W. 1633/32, } \\
\text { IT } 34 \text {, } \\
\text { Univ, of Wisconsin }\end{array}$ & $\begin{array}{l}\text { Silty lime- } \\
\text { stone. }\end{array}$ & $\begin{array}{l}\text { Conodonts: } \\
\text { Plattorm fragments of } \\
\text { Epigondolellia? or Neogondolella } \\
\text { polygnathiformis? }\end{array}$ & $\begin{array}{l}\text { Late } \\
\text { Triassic } \\
\text { (Kamian to } \\
\text { Norian). }\end{array}$ & $\begin{array}{l}\text { D.L Clark in } \\
\text { Sherwood and } \\
\text { Craddock, } 1979 .\end{array}$ & \\
\hline $\begin{array}{l}96 \\
\text { Kcs } \\
\text { B-3 }\end{array}$ & $\begin{array}{l}63^{\circ} 20^{\prime} 40^{\prime \prime} \\
148^{\circ} 19^{\prime} 35^{\prime \prime}\end{array}$ & $81 \mathrm{ACy}-92$ & do. & $\begin{array}{l}\text { Conodonts: } \\
\text { Epigondolella? sp. }\end{array}$ & do. & $\begin{array}{l}\text { M.W. Mulien, } \\
\text { this report. }\end{array}$ & CAI-6. \\
\hline $\begin{array}{l}96 \mathrm{~A} \\
\text { Kcs } \\
\text { B-3 }\end{array}$ & $\begin{array}{l}63^{\circ} 23^{\prime} 43^{\prime \prime} \\
148^{\circ} 21^{\prime} 36^{\prime \prime}\end{array}$ & $79 A C y-8$ & do. & $\begin{array}{l}\text { Conodonts: } \\
\text { Epigondoielia primitia }\end{array}$ & $\begin{array}{l}\text { Late } \\
\text { Triassic } \\
\text { (late Kar- } \\
\text { nian to early } \\
\text { Norian). }\end{array}$ & do. & CAI-5 \\
\hline $\begin{array}{l}97 \\
\text { Kvs } \\
\text { A-6 }\end{array}$ & $\begin{array}{l}63^{\circ} 01^{\prime} 55^{\prime \prime} \\
149^{\circ} 37^{\prime} 20^{\prime \prime}\end{array}$ & $78 \mathrm{AC} y-52,53$ & Marble & $\begin{array}{l}\text { Hydrozoan: } \\
\text { Heterastridium sp. } \\
\text { Mollusc: } \\
\text { Monotis subcircularis }\end{array}$ & $\begin{array}{l}\text { Late } \\
\text { Triassic } \\
\text { (late } \\
\text { Norian). }\end{array}$ & $\begin{array}{l}\text { N.J. Silberling, } \\
\text { written commun., } \\
1978 \text {. }\end{array}$ & \\
\hline
\end{tabular}


Table 2. Fossil data from the Healy quadrangle, Alaska-Continued

\begin{tabular}{|c|c|c|c|c|c|c|c|}
\hline $\begin{array}{l}\text { Map No., } \\
\text { map unit, } \\
\text { quad. No. }\end{array}$ & $\begin{array}{l}\text { Location } \\
\text { lat }(\mathbb{N} .) \text { and } \\
\text { long (W.) }\end{array}$ & $\begin{array}{l}\text { Field No. (s), } \\
\text { (USGS Museum No.), } \\
\text { and (or) collector }\end{array}$ & Lithology & Fossils & $\begin{array}{l}\text { Fossil } \\
\text { age }\end{array}$ & $\begin{array}{l}\text { Determiner } \\
\text { and (or) reference }\end{array}$ & Comments \\
\hline $\begin{array}{l}98 \\
\text { Kivs } \\
\text { A-6 }\end{array}$ & $\begin{array}{l}63^{\circ} 02^{\prime} 48^{\prime \prime} \\
149^{\circ} 34^{\prime} 20^{\prime}\end{array}$ & 80 AMM -23 & Argillite & $\begin{array}{l}\text { Mollusc: } \\
\text { Monotis cf. M. subcircularis }\end{array}$ & $\begin{array}{l}\text { Late } \\
\text { Triassic } \\
\text { (Nonian). }\end{array}$ & $\begin{array}{l}\text { N.d. Silberling. } \\
\text { written cormmun., } \\
1983 \text {. }\end{array}$ & $\begin{array}{l}\text { Float from road-cut } \\
\text { exposure. }\end{array}$ \\
\hline $\begin{array}{l}99 \\
\text { Kivs } \\
\text { A.5 }\end{array}$ & $\begin{array}{l}63^{\circ} 10^{\prime} 05^{\prime \prime} \\
149^{\circ} 11^{\prime} 30^{\prime \prime}\end{array}$ & $77-S-152$ & do. & $\begin{array}{l}\text { Hydrozoan: } \\
\text { Hetentstridium sp. } \\
\text { Mollusc: } \\
\text { Monotis subcircularis }\end{array}$ & $\begin{array}{l}\text { Late } \\
\text { Triassic } \\
\text { (late } \\
\text { Norian). }\end{array}$ & $\begin{array}{l}\text { N.J. Silberling, } \\
\text { written cormmun., } \\
1978 .\end{array}$ & \\
\hline $\begin{array}{l}100 \\
\text { Kvs } \\
\text { TK D-2 }\end{array}$ & $\begin{array}{l}62^{\circ} 58^{\prime} 53^{\prime \prime} \\
147^{\circ} 52^{\prime} 44^{\prime \prime} \\
\text { Talkeetna } \\
\text { Mtns. quad. }\end{array}$ & 80 AMM-2 & $\begin{array}{l}\text { Limestone } \\
\text { clasts. }\end{array}$ & $\begin{array}{l}\text { Conodonts: } \\
\text { Neogondolella primitia } \\
\text { Epigondolella primitia } \\
\text { Chirodelia sp. } \\
\text { Mollusc: } \\
\text { Leptochondria? sp. }\end{array}$ & $\begin{array}{l}\text { Late } \\
\text { Triassic } \\
\text { (iate } \\
\text { Karnian to } \\
\text { early } \\
\text { Norian). }\end{array}$ & $\begin{array}{l}\text { M.W. Mullen, } \\
\text { this report, } \\
\text { N.d. Silberling. } \\
\text { written commun., } \\
1983 \text {. }\end{array}$ & $\begin{array}{l}\text { Limestone clasts in } \\
\text { basaltic tuff. Clasts } \\
\text { possibly derived from } \\
\text { Chitistone and Nizina } \\
\text { Limestone of unit } \bar{k} \mathrm{cn} . \\
\text { CAI-6. }\end{array}$ \\
\hline $\begin{array}{l}101 \\
\text { Kvs } \\
\text { A-1 }\end{array}$ & $\begin{array}{l}63^{\circ} 08^{\prime} 26^{\circ} \\
147^{\circ} 10^{\prime} 00^{\prime \prime}\end{array}$ & $\begin{array}{l}\text { T.E. Smith of } \\
\text { AKDGGS }\end{array}$ & Marble & $\begin{array}{l}\text { Scleractinian corals, i.e., } \\
\text { Thamnasteria? sp. } \\
\text { Spongiomorphid coelenterates }\end{array}$ & $\begin{array}{l}\text { Late } \\
\text { Trias- } \\
\text { sicl??. }\end{array}$ & $\begin{array}{l}\text { N.J. Silberling } \\
\text { in Smith, } 1981 \text {. }\end{array}$ & \\
\hline $\begin{array}{l}102 \\
\text { Kvs } \\
\text { A-1 }\end{array}$ & $\begin{array}{l}63^{\circ} 08^{\prime} 14^{\prime \prime} \\
147^{\circ} 10^{\prime} 44^{\prime \prime}\end{array}$ & $79 \mathrm{ARh}-28$ & do. & $\begin{array}{l}\text { Hydrozaan: } \\
\text { Heterastridium sp. }\end{array}$ & $\begin{array}{l}\text { Late } \\
\text { Triassic } \\
\text { (late } \\
\text { Norian!. }\end{array}$ & $\begin{array}{l}\text { N.d. Silberling } \\
\text { in Silberling and } \\
\text { others, } 19816 \text {. }\end{array}$ & \\
\hline $\begin{array}{l}103 \\
\text { Ken } \\
\text { A-2 }\end{array}$ & $\begin{array}{l}63^{\circ} 01^{\prime} 38^{\prime \prime} \\
147^{\circ} 34^{\prime} 50^{\prime \prime}\end{array}$ & $80 A C_{y}-8$ & Limestone & $\begin{array}{l}\text { Conodonts: } \\
\text { Epigondolella primitia } \\
\text { Neogondolelia cf. } N \text {. } \\
\text { polygnathiformis } \\
\text { Cypriodella sp. } \\
\text { Molluscs: } \\
\text { Halobia cf. } H \text {. superba } \\
\text { Arcestes sp. }\end{array}$ & $\begin{array}{l}\text { Late } \\
\text { Triassic } \\
\text { flate } \\
\text { Kamian to } \\
\text { early } \\
\text { Norian). }\end{array}$ & $\begin{array}{l}\text { M.W. Mullen, } \\
\text { this report; } \\
\text { N.d. Silberling, } \\
\text { written commun., } \\
1983 \text {. }\end{array}$ & CAl- 1.5 to 2 \\
\hline $\begin{array}{l}204 \\
\text { Ken } \\
\text { A-2 }\end{array}$ & $\begin{array}{l}63^{\circ} 03^{\prime} 48^{\prime \prime} \\
147^{\circ} 34^{\prime} 54^{\prime \prime}\end{array}$ & $80 A C_{y-13}$ & do. & Barren of Microfossils & No data & $\begin{array}{l}\text { M.W. Mullen, } \\
\text { this report; }\end{array}$ & $\begin{array}{l}\text { This sample contains chert } \\
\text { nodules and streamers. }\end{array}$ \\
\hline $\begin{array}{l}105 \\
\mathrm{k} c n \\
\mathrm{~A}-1\end{array}$ & $\begin{array}{l}63^{\circ} 09^{\prime} 08^{\prime \prime} \\
147^{\circ} 00^{\prime} 22^{\prime \prime}\end{array}$ & $\begin{array}{l}\text { (USGS Mesozoic } \\
\text { boc. M6750) }\end{array}$ & do. & $\begin{array}{l}\text { Molluscs: } \\
\text { Trophites cf. T. kellyi } \\
\text { Halobia ct. H. superba }\end{array}$ & $\begin{array}{l}\text { Late } \\
\text { Triassic } \\
\text { (late } \\
\text { Karnian). }\end{array}$ & $\begin{array}{l}\text { N.J. Silberting } \\
\text { in Silbering } \\
\text { and others, } 1981 \mathrm{~b} .\end{array}$ & \\
\hline $\begin{array}{l}106 \\
\text { Kn } \\
\text { A-1 }\end{array}$ & $\begin{array}{l}63^{\circ} 08^{\prime} 28^{\prime \prime} \\
147^{\circ} 08^{\prime} 22^{\prime \prime}\end{array}$ & $79 \mathrm{ACQ}-16$ & do. & $\begin{array}{l}\text { Mollusc } \\
\quad \text { Hajobia cf. H. superba }\end{array}$ & $\begin{array}{l}\text { Late } \\
\text { Triassic } \\
\text { (late } \\
\text { Kamian to } \\
\text { early Norian) }\end{array}$ & $\begin{array}{l}\text { N.J. Silberling. } \\
\text { written commun., } \\
1980 .\end{array}$ & $\begin{array}{l}\text { Fault sliver of unit } \mathrm{Kcn} \text {, } \\
\text { or a sedimentary lense } \\
\text { within the Nikolaj Green- } \\
\text { stone (unit } \mathrm{kn} \text { ). }\end{array}$ \\
\hline
\end{tabular}




\begin{tabular}{|c|c|c|c|c|c|c|c|c|}
\hline & $\begin{array}{l}107 \\
J \mathrm{~J} r \mathrm{rs} \\
\mathrm{A}-6\end{array}$ & $\begin{array}{l}63^{\circ} 02^{\prime} 07^{\prime \prime} \\
149^{\circ} 54^{\prime} 10^{\circ}\end{array}$ & $76-N-135$ & Sandstone & \multicolumn{2}{|c|}{$\begin{array}{l}\text { Ammonite: } \\
\text { duvavites cf. J. magnus }\end{array}$} & $\begin{array}{l}\text { Late } \\
\text { Triassic } \\
\text { (middle } \\
\text { Norian). }\end{array}$ & $\begin{array}{l}\text { N.J. Silberting } \\
\text { in Jones and } \\
\text { others, } 1980 \text {. }\end{array}$ \\
\hline & $\begin{array}{l}108 \\
j \pi r s \\
\text { A-6 }\end{array}$ & $\begin{array}{l}63^{\circ} 03^{\prime} 08^{\prime \prime} \\
149^{\circ} 55^{\prime} 30^{\prime \prime} \\
63^{\circ} 03^{\prime} 16^{\prime \prime} \\
149^{\circ} 55^{\prime} 46^{\prime \prime}\end{array}$ & $\begin{array}{l}76-5-303 \\
76-5-304\end{array}$ & do. & \multicolumn{2}{|c|}{$\begin{array}{l}\text { Hydrozoan: } \\
\text { Heterastridium sp. }\end{array}$} & $\begin{array}{l}\text { Late } \\
\text { Triassic } \\
\text { (liate } \\
\text { Norian) }\end{array}$ & do. \\
\hline & $\begin{array}{l}109 \\
\text { JKrs } \\
\text { A.6 }\end{array}$ & $\begin{array}{l}63^{\circ} 04^{\prime} 33^{\prime \prime} \\
149^{\circ} 52^{\prime} 08^{\prime \prime}\end{array}$ & $76-\mathrm{N}-138$ & do. & \multicolumn{2}{|c|}{ Junavites cf. d. magnus } & $\begin{array}{l}\text { Late } \\
\text { Triassic } \\
\text { (middle } \\
\text { Noriant. }\end{array}$ & do. \\
\hline & $\begin{array}{l}110 \\
\text { JWrs } \\
\text { A-6 }\end{array}$ & $\begin{array}{l}62^{\circ} 05^{\prime} 14^{\prime \prime} \\
149^{\circ} 55^{\prime} 36^{\prime \prime}\end{array}$ & $77-5-131$ & do. & \multicolumn{2}{|c|}{$\begin{array}{l}\text { Hydrozoan: } \\
\text { Heterastridium sp. }\end{array}$} & $\begin{array}{l}\text { Late } \\
\text { Triassic } \\
\text { (late } \\
\text { Norian). }\end{array}$ & do. \\
\hline & $\begin{array}{l}111 \\
\text { JKrs } \\
\text { A-6 }\end{array}$ & $\begin{array}{l}63^{\circ} 08^{\prime} 12^{\prime \prime} \\
149^{\circ} 46^{\prime} 23^{\prime \prime} \\
63^{\circ} 08^{\prime} 29^{\prime \prime} \\
149^{\circ} 08^{\prime} 11^{\prime \prime}\end{array}$ & $\begin{array}{l}\text { (USGS Mesozoic } \\
\text { bcalities } \\
\text { M6504 and M6505) }\end{array}$ & do. & \multicolumn{2}{|c|}{$\begin{array}{l}\text { 6504: Juvatinid ammonite } \\
\text { 6505: Pseudosinenites sp., } \\
\text { indojuvavites sp., } \\
\text { and other ammonites }\end{array}$} & $\begin{array}{l}\text { Late } \\
\text { Triassic } \\
\text { (Kamian to } \\
\text { Norian). }\end{array}$ & do. \\
\hline & $\begin{array}{l}112 \\
\text { JKrs } \\
\text { A-6 }\end{array}$ & $\begin{array}{l}63^{\circ} 09^{\prime} 11^{\prime \prime} \\
149^{\circ} 46^{\prime} 30^{\prime \prime}\end{array}$ & $76-5-297$ & do. & \multicolumn{2}{|c|}{$\begin{array}{l}\text { Molluse: } \\
\text { Cassianella sp. }\end{array}$} & $\begin{array}{l}\text { Late } \\
\text { Triassic }\end{array}$ & do. \\
\hline \multirow{6}{*}{ G } & $\begin{array}{l}113 \\
\text { Jkrs } \\
\text { A-6 }\end{array}$ & $\begin{array}{l}63^{\circ} 12^{\prime} 06^{\prime \prime} \\
149^{\circ} 44^{\prime} 23^{\prime \prime} \\
63^{\circ} 11^{\prime} 59^{\prime \prime} \\
149^{\circ} 44^{\prime} 06^{\prime \prime}\end{array}$ & $\begin{array}{l}\text { 76.S } 333 \\
\text { fUSGS Mesozoic } \\
\text { loc. } 31266 \\
76-5-342\end{array}$ & Sandstone & $\begin{array}{l}\text { 333: } \\
\text { 342: }\end{array}$ & $\begin{array}{l}\text { Vermiceras (Paracaloceras) } \\
\text { cf. V. (P) nursicastatum } \\
\text { Psiloceras? canadense } \\
\text { Weyla sp. } \\
\text { Lima? sp. } \\
\text { Eopecten? sp. } \\
\text { Septocardia? sp. }\end{array}$ & $\begin{array}{l}\text { Early } \\
\text { Jurassic } \\
\text { (early } \\
\text { Sinetnur- } \\
\text { ianl; Late } \\
\text { Triassic. }\end{array}$ & $\begin{array}{l}\text { R.W. Imlay, } \\
\text { written commun., } \\
1980 ; \text { N.J. } \\
\text { Silberling in } \\
\text { Janes and others, } \\
1980 .\end{array}$ \\
\hline & $\begin{array}{c}114 \\
5 \mathrm{krs} \\
\mathrm{A}-6\end{array}$ & $\begin{array}{l}63^{\circ} 12^{\prime} 31^{\prime \prime} \\
149^{\circ} 42^{\prime} 42^{\prime \prime}\end{array}$ & $76-5-343$ & do. & \multicolumn{2}{|c|}{$\begin{array}{l}\text { Molluses: } \\
\text { Cassianella sp. } \\
\text { Septocardia? sp. }\end{array}$} & $\begin{array}{l}\text { Late } \\
\text { Triassic. }\end{array}$ & $\begin{array}{l}\text { N.J. Silberling } \\
\text { in Jones and } \\
\text { others, } 1980 \text {. }\end{array}$ \\
\hline & $\begin{array}{l}115 \\
\text { K16 } \\
\text { A-6 }\end{array}$ & $\begin{array}{l}63^{\circ} 03^{\prime} 55^{\prime \prime} \\
149^{\circ} 56^{\prime} 20^{\circ}\end{array}$ & $76-5-306$ & Limestone & \multicolumn{2}{|c|}{$\begin{array}{l}\text { Scleractinian corals } \\
\text { Megalodontid bivalves }\end{array}$} & do. & do. \\
\hline & $\begin{array}{l}116 \\
\text { K } 16 \\
\text { A-6 }\end{array}$ & $\begin{array}{l}63^{\circ} 04^{\prime} 48^{\prime \prime} \\
149^{\circ} 59^{\prime} 31^{\prime \prime}\end{array}$ & $76-5-324$ & do. & \multicolumn{2}{|c|}{ do. } & do. & do. \\
\hline & $\begin{array}{l}117 \\
\text { JTlb } \\
\text { A-6 }\end{array}$ & $\begin{array}{l}63^{\circ} 13^{\prime} 12^{\prime \prime} \\
149^{\circ} 45^{\prime} 33^{\prime \prime}\end{array}$ & $77-5-111$ & do. & \multicolumn{2}{|c|}{$\begin{array}{l}\text { Spondylospira? sp. } \\
\text { Scleractinian corals }\end{array}$} & $\begin{array}{l}\text { Late } \\
\text { Triassic } \\
\text { (Norian). }\end{array}$ & do. \\
\hline & $\begin{array}{l}118 \\
\mathrm{kcg} \\
\mathrm{B}-4\end{array}$ & $\begin{array}{l}63^{\circ} 21^{\prime} 15^{\prime \prime} \\
148^{\circ} 51^{\prime} 05^{\prime \prime}\end{array}$ & 77ーよ-9 & $\begin{array}{l}\text { Conglomerate; } \\
\text { chert clasts } \\
\text { in conglomer- } \\
\text { ate. }\end{array}$ & \multicolumn{2}{|c|}{$\begin{array}{l}\text { Hydrozoan: } \\
\text { Heterastridium sp:; } \\
\text { Radiolarians }\end{array}$} & $\begin{array}{l}\text { Late } \\
\text { Triassic } \\
\text { (late } \\
\text { Norian); } \\
\text { Permian. }\end{array}$ & $\begin{array}{l}\text { D.L. Jones and } \\
\text { B.K. Holdsworth } \\
\text { in Jones and } \\
\text { others, } 1980 .\end{array}$ \\
\hline
\end{tabular}


Table 2. Fossil data from the Healy quadrangle, Alaska-Continued

\begin{tabular}{|c|c|c|c|c|c|c|c|}
\hline $\begin{array}{l}\text { Map No., } \\
\text { map unit, } \\
\text { qued No. }\end{array}$ & $\begin{array}{l}\text { Locetion } \\
\text { lat (N) and } \\
\text { long }(W .)\end{array}$ & $\begin{array}{l}\text { Plete Na. (s), } \\
\text { (USGS Museum No). } \\
\text { and for) colloctor }\end{array}$ & Lithology & Fossils & $\begin{array}{l}\text { Fossi } \\
\text { age }\end{array}$ & $\begin{array}{l}\text { Determiner } \\
\text { and }(\text { or) reference }\end{array}$ & Comments \\
\hline $\begin{array}{l}119 \\
\text { Libd } \\
\text { B. }\end{array}$ & $\begin{array}{l}63.29 .55^{\circ} \\
149 \cdot 58^{\circ} 00^{\circ} \\
\text { (approx. loc) }\end{array}$ & $\begin{array}{l}\text { A-370, } \\
\text { Untv, of Alasha } \\
\text { Museum of Paleo. }\end{array}$ & Argitie & $\begin{array}{l}\text { Mollusc: } \\
\text { Haibbia d } H \text {. superba }\end{array}$ & $\begin{array}{l}\text { Late } \\
\text { Triassic } \\
\text { (Karrlan to } \\
\text { Norian) }\end{array}$ & $\begin{array}{l}\text { Gabert and } \\
\text { others. } 1984 .\end{array}$ & $\begin{array}{l}\text { Specimen is from clasic } \\
\text { interbed in pillowed } \\
\text { greenstone. }\end{array}$ \\
\hline $\begin{array}{l}120 \\
5 b d \\
B \cdot 6\end{array}$ & $\begin{array}{l}63^{\circ} 26^{\circ} 43^{\circ} \\
149^{\circ} 44^{\prime} 27^{\circ}\end{array}$ & $\begin{array}{l}83 \text { AMN-8, } \\
\text { (MR 6454) }\end{array}$ & $\begin{array}{l}\text { Sittstore and } \\
\text { argitite }\end{array}$ & $\begin{array}{l}\text { Radiolanans } \\
\text { Cantahom sp. } \\
\text { Gorgansium sp. } \\
\text { Ladonum sp. } \\
\text { Partanetsm foutert } \\
\text { Pseudoheliodiscus sp. }\end{array}$ & $\begin{array}{l}\text { Late } \\
\text { Triassic } \\
\text { tiate } \\
\text { Norianl: }\end{array}$ & $\begin{array}{l}\text { C.D. Blome, } \\
\text { watten commun, } \\
\text { I9e4 }\end{array}$ & $\begin{array}{l}\text { Sample trom tiun-bedded } \\
\text { tuebidite sequence inter. } \\
\text { calatod with pillow booalt } \\
\text { Saraple also contains } \\
\text { abundant sponge splailes } \\
\text { and volcanic ash shards. }\end{array}$ \\
\hline $\begin{array}{l}121 \\
\text { IPs } \\
B .6\end{array}$ & $\begin{array}{l}622^{\prime} \cdot 35^{\circ} \\
149^{\prime} 52^{\prime} 35^{\prime}\end{array}$ & $80-5-13$ & Chen & Conodonts and radiolarians & $\begin{array}{l}\text { Late } \\
\text { Triastic } \\
\text { (Kamian) }\end{array}$ & $\begin{array}{l}\text { BR. Worthow and } \\
\text { D.L Jones in } \\
\text { Jones and others, } \\
1983 \text {. }\end{array}$ & \\
\hline $\begin{array}{l}122 \\
\text { iPs } \\
\text { C.5 }\end{array}$ & $\begin{array}{l}630^{\prime} 00^{\circ} \\
149^{\prime} 10^{\prime} 10^{\prime}\end{array}$ & $\begin{array}{l}\text { 82-DP-45, } \\
\text { (M-33064) }\end{array}$ & $\begin{array}{l}\text { Impute } \\
\text { Imestone. }\end{array}$ & $\begin{array}{l}\text { Conodonts: } \\
\text { Neogondolella d N. shoshonensis }\end{array}$ & $\begin{array}{l}\text { Middle } \\
\text { Trassic } \\
\text { (Anisian). }\end{array}$ & $\begin{array}{l}\text { 8.R. Warclaw, } \\
\text { wrtten commun. } \\
\text { i9s. }\end{array}$ & $\begin{array}{l}\text { Sample from fine-grained } \\
\text { carbonate in sandstone and } \\
\text { shale sequence. }\end{array}$ \\
\hline $\begin{array}{l}123 \\
1 P_{5} \\
B .5\end{array}$ & $\begin{array}{l}63^{\circ} 40^{\circ} 07 \\
149^{\circ} 36^{\prime} 25^{\circ}\end{array}$ & $\begin{array}{l}78-5-412 \\
(27360-P C)\end{array}$ & $\begin{array}{l}\text { Limeitone and } \\
\text { slicifed } \\
\text { limestone } \\
\text { diasts in } \\
\text { conglomerate. }\end{array}$ & 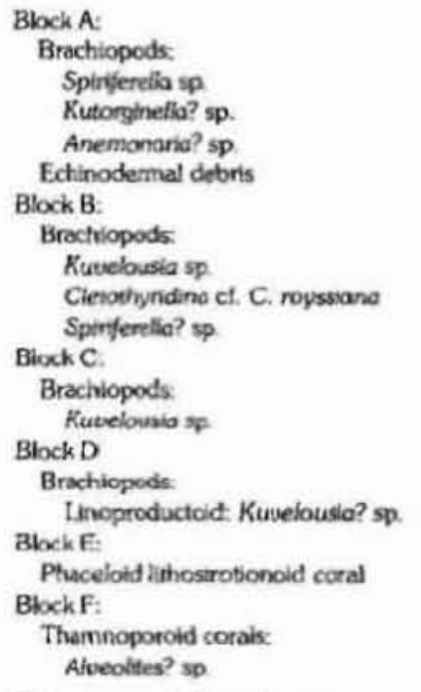 & $\begin{array}{l}\text { Mud. } \\
\text { Permian } \\
\text { (Leonardi- } \\
\text { an to } \\
\text { Wordian). } \\
\text { Mid- } \\
\text { Permian } \\
\text { (Wordian). } \\
\text { do. } \\
\text { do. }\end{array}$ & $\begin{array}{l}\text { d.T. Dutio } \\
\text { withen commun. } \\
\text { 1978, and } \\
\text { J.T. Dutho in } \\
\text { Jones ond others, } \\
\text { 1983. }\end{array}$ & $\begin{array}{l}\text { Siump blocks and cobbles } \\
\text { within Triassict? } \\
\text { condomerate. }\end{array}$ \\
\hline & & $\begin{array}{l}\text { U.W. 1574/12, } \\
\text { YF 423, } \\
\text { Univ. of Wisconsin }\end{array}$ & $\begin{array}{l}\text { Limestone cob- } \\
\text { blos in con- } \\
\text { glomerate. }\end{array}$ & $\begin{array}{l}\text { Thamopore of T. cenvicomis } \\
\text { Echinoderm, brochiopod, and } \\
\text { bryospan fragmenis. }\end{array}$ & $\begin{array}{l}\text { Middle- } \\
\text { or Late } \\
\text { Devonian }\end{array}$ & $\begin{array}{l}\text { Thomas Dekeyser in } \\
\text { Sherwood and } \\
\text { Caddock, } 1979 .\end{array}$ & \\
\hline
\end{tabular}




\begin{tabular}{|c|c|c|c|c|c|c|c|c|}
\hline & $\begin{array}{l}124 \\
\text { KPs } \\
\text { C-5 }\end{array}$ & $\begin{array}{l}63^{\circ} 30^{\prime} 08^{\prime \prime} \\
149^{\circ} 07^{\prime} 49^{\circ}\end{array}$ & $\begin{array}{l}\text { U.W. } 1574 / 13 \text {, } \\
\text { YF } 338 \text {, } \\
\text { Univ. of Wisconsin }\end{array}$ & do. & $\begin{array}{l}\text { Amphipora of. A. ramosa } \\
\text { Anostylostroma sp. } \\
\text { Hammatostroma cf. H. aibertende }\end{array}$ & $\begin{array}{l}\text { Late or } \\
\text { Middle- } \\
\text { Devonian. }\end{array}$ & do. & $\begin{array}{l}\text { Cobbles within Triassic(?) } \\
\text { conglomerate. }\end{array}$ \\
\hline & $\begin{array}{l}125 \\
\text { B.PS } \\
\text { B-5 }\end{array}$ & $\begin{array}{l}63^{\circ} 29^{\prime} 20^{\circ} \\
149^{\circ} 05^{\circ} 00^{\circ} \\
\text { (approx. loc.) }\end{array}$ & $\begin{array}{l}80-\text { S- } 502 \\
\text { U.W. } 1574 / 14, \\
\text { YF } 362 \text {, } \\
\text { Univ. of Wisconsin }\end{array}$ & $\begin{array}{l}\text { Limestone } \\
\text { clasts in con- } \\
\text { glomerate. }\end{array}$ & $\begin{array}{l}\text { Bryozoans, brachiopods, and } \\
\text { echinoderm fragments. }\end{array}$ & $\begin{array}{l}\text { Carboni- } \\
\text { ferous or } \\
\text { Permian. }\end{array}$ & $\begin{array}{l}\text { Jones and others, } \\
\text { 1983; Thomas Dekeyser } \\
\text { in Sherwood and } \\
\text { Craddock, } 1979 .\end{array}$ & $\begin{array}{l}\text { Displaced fossil debris in } \\
\text { Triassic?? conglomerate. }\end{array}$ \\
\hline & $\begin{array}{l}126 \\
\text { RPS } \\
\text { B-5 }\end{array}$ & $\begin{array}{l}63^{\circ} 28^{\prime} 55^{\prime \prime} \\
149^{\circ} 05^{\prime} 10^{\prime \prime} \\
\text { (approx. loc.) }\end{array}$ & $80-S-501$ & $\begin{array}{l}\text { Limestone } \\
\text { block in } \\
\text { conglomerate. }\end{array}$ & Conodonts & $\begin{array}{l}\text { Late Early } \\
\text { to early } \\
\text { Middle- } \\
\text { Devonian. }\end{array}$ & $\begin{array}{l}\text { B.R. Wardlaw in } \\
\text { Jones and others, } \\
1983 \text {. }\end{array}$ & $\begin{array}{l}\text { Slump biock of crinoidal } \\
\text { limestone within Trias- } \\
\text { sic(?) turbidite }\end{array}$ \\
\hline & $\begin{array}{l}127 \\
\text { KP P } \\
\text { B-5 }\end{array}$ & $\begin{array}{l}63^{\circ} 29^{\prime} 18^{\prime \prime} \\
149^{\circ} 04^{\prime} 03^{\prime \prime}\end{array}$ & $\begin{array}{l}\text { 80-JH-13, } \\
\text { (MR 2041); } \\
80-J \mathrm{H}-15\end{array}$ & Chert & Conodonts and radiolarians & $\begin{array}{l}\text { Late } \\
\text { Triassic } \\
\text { (Karnian). }\end{array}$ & $\begin{array}{l}\text { Jones and others, } \\
1983 .\end{array}$ & $\begin{array}{l}\text { Thin beds of chert inter- } \\
\text { bedded with argillite. }\end{array}$ \\
\hline & $\begin{array}{l}128 \\
\text { KPS } \\
\text { B.4 }\end{array}$ & $\begin{array}{l}63^{\circ} 29^{\prime} 04^{\prime \prime} \\
149^{\circ} 55^{\prime} 20^{\prime \prime}\end{array}$ & $\begin{array}{l}\text { U.W. } 1574 / 1 \text {, } \\
\text { MP } 224 \text {, } \\
\text { Univ. of Wisconsin }\end{array}$ & Limestone & Productid brachiopods & $\begin{array}{l}\text { Pennsyl- } \\
\text { vanian to } \\
\text { Permian. }\end{array}$ & $\begin{array}{l}\text { LR. Laudon in } \\
\text { Sherwood and } \\
\text { Craddock, } 1979 .\end{array}$ & \\
\hline & $\begin{array}{l}129 \\
\text { RDV } \\
\text { B-6 }\end{array}$ & $\begin{array}{l}63^{\circ} 15^{\prime} 12^{\prime \prime} \\
149^{\circ} 33^{\prime} 33^{\circ}\end{array}$ & $\begin{array}{l}68 \mathrm{AH} \mathrm{Ax}-272 \\
(23753-P C)\end{array}$ & do. & $\begin{array}{l}\text { Bryozoan: } \\
\text { Rhombotrypella sp. } \\
\text { Echinodermal debris, including } \\
\text { pelmatozoan columnals as much as } \\
1 \text { inch in diameter. }\end{array}$ & $\begin{array}{l}\text { Late } \\
\text { Paleozoic, } \\
\text { Permian(?). }\end{array}$ & $\begin{array}{l}\text { J.T. Dutro in } \\
\text { Hawley and Clark, } \\
1974 .\end{array}$ & \\
\hline \multirow[t]{4}{*}{ जુ } & $\begin{array}{l}130 \\
\text { RDv } \\
\text { A-6 }\end{array}$ & $\begin{array}{l}63^{\circ} 14^{\prime} 02^{\prime \prime} \\
149^{\circ} 36^{\prime} 44^{\prime \prime}\end{array}$ & $67 \mathrm{ACx}-74$ & do. & $\begin{array}{l}\text { Brachiopods: } \\
\text { Avonia? sp. } \\
\text { Martiniopsis? sp. } \\
\text { Bryozoan: } \\
\text { Rhombotrypella sp. } \\
\text { Crinoid columnals }\end{array}$ & Pemian(?) & do. & \\
\hline & $\begin{array}{l}131 \\
\text { RDv } \\
\text { A.6 }\end{array}$ & $\begin{array}{l}63^{\circ} 12^{\prime} 56^{\prime \prime} \\
149^{\circ} 40^{\prime} 55^{\prime}\end{array}$ & $\begin{array}{l}77-\mathrm{S}-101 \\
78 \mathrm{JCH}-1\end{array}$ & $\begin{array}{l}\text { do. } \\
\text { Phosphatic } \\
\text { chert. }\end{array}$ & $\begin{array}{l}\text { Ammonites of the Meekoceras } \\
\text { grocilitat's Zone } \\
\text { Conodonts: } \\
\text { Neogondolella jubata } \\
\text { "Neospathodus" conservativus }\end{array}$ & $\begin{array}{l}\text { Early } \\
\text { Triassic } \\
\text { (Smithian). } \\
\text { Early } \\
\text { Trassic } \\
\text { (Smithian). }\end{array}$ & $\begin{array}{l}\text { K.M. Nichols in } \\
\text { Nichols and } \\
\text { Stbering, } 1979 \text {; } \\
\text { Wardlaw, } 1982 \text {. }\end{array}$ & \\
\hline & $\begin{array}{l}132 \\
\text { RDv } \\
\text { A } 6\end{array}$ & $\begin{array}{l}63^{\circ} 13^{\prime} 12^{\prime \prime} \\
149^{\circ} 38^{\prime} 50^{\circ}\end{array}$ & (M5027) & Limestone & $\begin{array}{l}\text { Ammonites of the Meekoceras } \\
\text { gracilitatis Zone } \\
\text { Conodonts: } \\
\text { Ellisonia triassica } \\
\text { Neogondolella sibberlingi } \\
\text { Neogondolelia tozeri } \\
\text { Neospathodus waageni }\end{array}$ & $\begin{array}{l}\text { Early } \\
\text { Triassic } \\
\text { (Smithian). }\end{array}$ & do. & \\
\hline & $\begin{array}{l}133 \\
\text { RDv } \\
\text { A-6 }\end{array}$ & $\begin{array}{l}63^{\circ} 12^{\prime} 39^{\prime \prime} \\
149^{\circ} 38^{\prime} 16^{\prime \prime} \\
63^{\circ} 12^{\prime} 33^{\prime \prime} \\
149^{\circ} 38^{\prime} 14^{\prime \prime}\end{array}$ & $\begin{array}{l}76-1-1 \\
76-1-2\end{array}$ & $\begin{array}{l}\text { Chert and } \\
\text { volcanic } \\
\text { conglomer- } \\
\text { ate or breccia. }\end{array}$ & $\begin{array}{l}\text { Radiolarians } \\
\text { Brachiopods: } \\
\text { Fimbrinia sp. } \\
\text { Antiquatonia? sp. } \\
\text { Rugatia? sp. }\end{array}$ & $\begin{array}{l}\text { Carboni- } \\
\text { ferous??); } \\
\text { Early } \\
\text { Permian } \\
\text { (Wolfcamp- } \\
\text { ian to Leonard- } \\
\text { ian). }\end{array}$ & $\begin{array}{l}\text { D.L. Jones and } \\
\text { J.T. Dutro in } \\
\text { Jones and others, } \\
1980 \text {. }\end{array}$ & \\
\hline
\end{tabular}


Table 2. Fossil data from the Healy quadrangle, Alaska-Continued

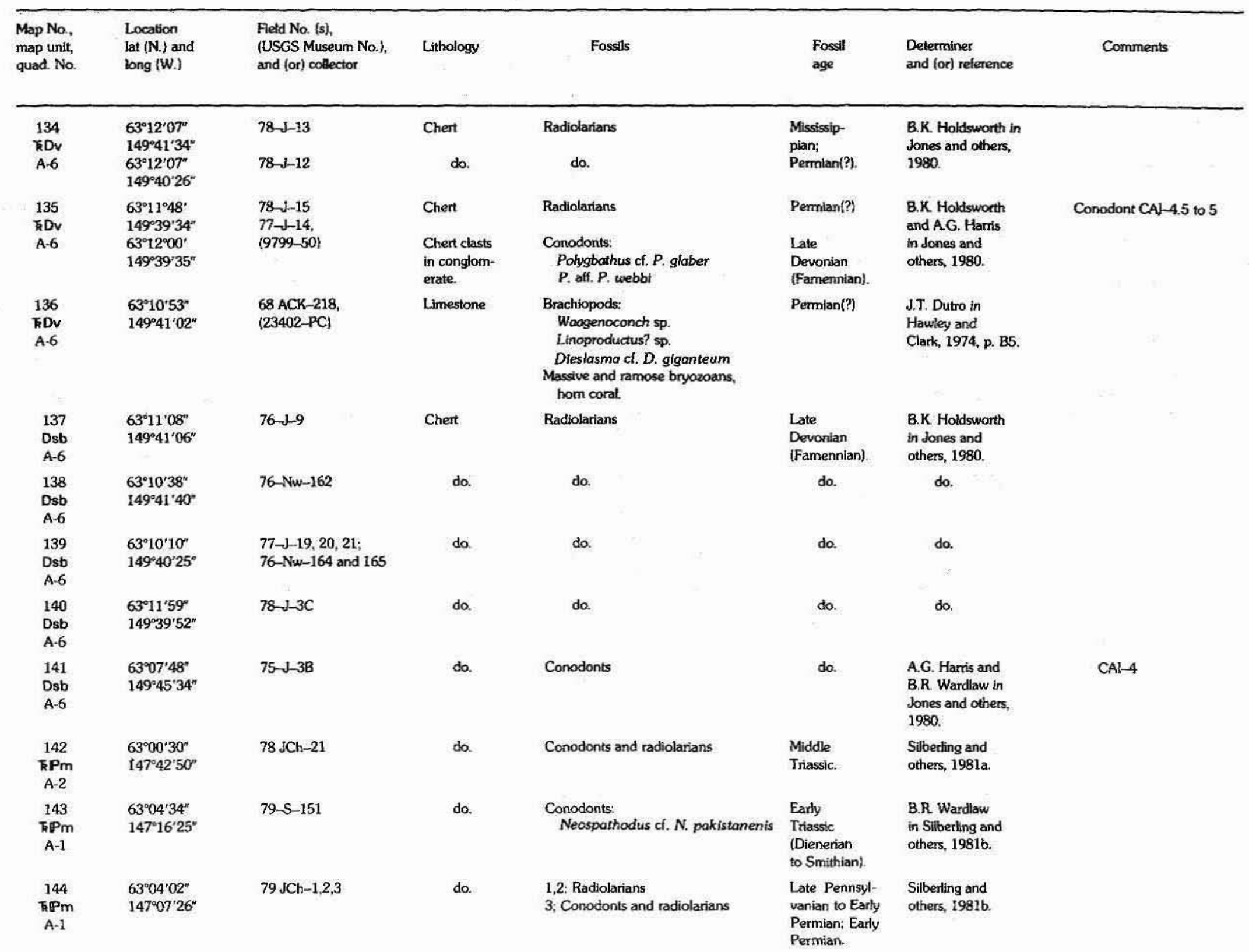




\begin{tabular}{|c|c|c|c|c|c|c|c|c|}
\hline & $\underset{\mathrm{A}-1}{145}$ & $\begin{array}{l}63^{\circ} 04^{\prime} 18 \\
147^{\circ} 04^{\prime} 52^{\prime}\end{array}$ & 78.JCh-24 & do. & Radiolarians & Triassic & do. & \\
\hline & $\underset{\text { A-1 }}{146}$ & $\begin{array}{l}63^{\circ} 04^{\prime} 44^{\prime \prime} \\
147^{\circ} 04^{\prime} 02^{\prime \prime}\end{array}$ & $78 \mathrm{JCh}-30$ & do. & do. & Permian & do. & \\
\hline & $\underset{\mathrm{A}-1}{147}$ & $\begin{array}{l}63^{\circ} 04^{\prime} 02^{\prime \prime} \\
147^{\circ} 03^{\prime} 18^{\prime \prime}\end{array}$ & $78-5-502$ & Limestone & Brachiopods & $\begin{array}{l}\text { Early } \\
\text { Permian. }\end{array}$ & $\begin{array}{l}\text { BR Wardiaw } \\
\text { in Silberling and } \\
\text { others, 1981b. }\end{array}$ & \\
\hline & $\begin{array}{l}148 \\
\text { MDt } \\
\text { D-2 }\end{array}$ & $\begin{array}{l}63^{\circ} 57^{\prime} 06^{\circ} \\
147^{\circ} 41^{\prime} 24^{\circ} \\
\text { do. }\end{array}$ & $\begin{array}{l}\text { Unavalable } \\
\text { CC-Healy D-2 }\end{array}$ & Marble & $\begin{array}{l}\text { Tabulate coral: } \\
\text { Syringopora sp. } \\
\text { Conodonts: } \\
\text { Polygnothus sp. } \\
\text { Ramilorm elements }\end{array}$ & $\begin{array}{l}\text { Mississip- } \\
\text { pian(?). } \\
\text { Middle Devonian } \\
\text { to Early } \\
\text { Missis- } \\
\text { sippian. }\end{array}$ & $\begin{array}{l}\text { Hejen Duncan in } \\
\text { Werhrghaltg, } \\
1968 \text {. } \\
\text { AG. Harris. } \\
\text { written comm. } \\
1985 .\end{array}$ & $\mathrm{CAl}-5$ \\
\hline & $\begin{array}{l}149 \\
D m b \\
D-3\end{array}$ & $\begin{array}{l}63^{\circ} 46^{\prime} 40^{\prime \prime} \\
148^{\prime} 26^{\prime} 40^{\circ}\end{array}$ & $\begin{array}{l}\text { U.W. 1583/12, } \\
\text { YF 72, } \\
\text { Univ of Wisconsin }\end{array}$ & do. & $\begin{array}{l}\text { Conodonts } \\
\text { Paimatolepis of. P. marginata } \\
\text { icriodus cf. I. symmetricus of } \\
\text { I. df I ateernatus } \\
\text { Polygnathus sp. }\end{array}$ & $\begin{array}{l}\text { Late } \\
\text { Devonian } \\
\text { flate } \\
\text { Frasnian } \\
\text { to early } \\
\text { Famennian) }\end{array}$ & $\begin{array}{l}\text { D. L. Clark in } \\
\text { Sherwood and } \\
\text { Craddock, } 1979\end{array}$ & \\
\hline \multirow[t]{7}{*}{9} & $\begin{array}{l}150 \\
\text { Dmb } \\
\text { D-2 }\end{array}$ & $\begin{array}{l}53^{\circ} 46^{\prime} 28^{\prime \prime} \\
147^{\circ} 40^{\prime} 28^{\prime \prime}\end{array}$ & 82 AMM-19 & do. & Barten of microlossils & No data & $\begin{array}{l}\text { M.W. Mulen, } \\
\text { this report }\end{array}$ & $\begin{array}{l}\text { Sarnple trom thin marble } \\
\text { interbed in greenschist } \\
\text { and phylitite sequence. }\end{array}$ \\
\hline & $\begin{array}{l}151 \\
\text { Dmb } \\
\text { D.1 }\end{array}$ & $\begin{array}{l}63^{\circ} 45^{\prime} 28^{\prime \prime} \\
147^{\prime} 29^{\circ} 05^{\prime \prime}\end{array}$ & $\begin{array}{l}\text { U.W. } 1622 / 38 \text {, } \\
\text { K } 483 \text {, } \\
\text { Univ. of Whsconsin } \\
76-5-306\end{array}$ & do. & $\begin{array}{l}\text { Conodonts: } \\
\text { Polygnathus sp. }\end{array}$ & $\begin{array}{l}\text { Devonian } \\
\text { to Missis- } \\
\text { sippian. }\end{array}$ & $\begin{array}{l}\text { D.L. Clark in } \\
\text { Sherwood and } \\
\text { Craddock, 1979; } \\
\text { M.W. Mullen, } \\
\text { this report }\end{array}$ & $\begin{array}{l}\text { Specimens were reexamined } \\
\text { and photographed with the } \\
\text { SEM CAl- } 6 \text { to } 6.5 \text {. }\end{array}$ \\
\hline & $\begin{array}{c}152 \\
\text { Dmb } \\
\text { D.1 }\end{array}$ & $\begin{array}{l}63^{\circ} 45^{\circ} 22^{\circ} \\
147^{\circ} 29^{\circ} 00^{\circ}\end{array}$ & $\begin{array}{l}\text { U.W. } 1633 / 04, \\
\text { K 482, } \\
\text { Univ. of Wisconsin }\end{array}$ & do. & $\begin{array}{l}\text { Conodonts: } \\
\text { Lingonodinalom or } \\
\text { prionlodinaform eiement } \\
\text { fragment }\end{array}$ & $\begin{array}{l}\text { Devonian } \\
\text { to Missis- } \\
\text { sipplan }\end{array}$ & do. & $\begin{array}{l}\text { Specimens were reexamined } \\
\text { and photographed with the } \\
\text { SEM. CAL- } 6 \text { to } 6.5 \text {. }\end{array}$ \\
\hline & $\begin{array}{l}153 \\
\text { Dms } \\
\text { C.6 }\end{array}$ & $\begin{array}{l}63^{\circ} 39^{\prime} 40^{\circ} \\
149^{\circ} 39^{\prime} 40^{\circ}\end{array}$ & Unavallable & da & $\begin{array}{l}\text { Amphipora? sp. } \\
\text { Disphyltum? sp. } \\
\text { Grypophyllum? sp. }\end{array}$ & $\begin{array}{l}\text { Middle\{? } \\
\text { Devonian }\end{array}$ & $\begin{array}{l}\text { W.A. Oliver in } \\
\text { Gilbert and } \\
\text { Redrnan, } 1977 \text {. }\end{array}$ & \\
\hline & $\begin{array}{l}154 \\
\text { Oms } \\
\text { C-6 }\end{array}$ & $\begin{array}{l}63^{\circ} 40^{\prime} 02^{*} \\
149^{\circ} 49^{\prime} 28^{*}\end{array}$ & do. & do. & Disphylum? sp. & $\begin{array}{l}\text { Middle } \\
\text { or early } \\
\text { Late Devon- } \\
\text { lan. }\end{array}$ & do. & \\
\hline & $\begin{array}{l}155 \\
\text { Dms } \\
\text { C.6 }\end{array}$ & $\begin{array}{l}63^{\circ} 40^{\prime} 20^{\circ} \\
149^{\circ} 48^{\prime} 55^{\circ}\end{array}$ & do. & da & $\begin{array}{l}\text { Disphyilum? sp. } \\
\text { Phillipsastroed sp. } \\
\text { Tobuiophyilum sp. }\end{array}$ & $\begin{array}{l}\text { Late } \\
\text { Devonian } \\
\text { (Frasnian) }\end{array}$ & da. & \\
\hline & $\begin{array}{l}156 \\
\text { Dms } \\
\text { C-6 }\end{array}$ & $\begin{array}{l}63^{\circ} 43^{\prime} 12^{*} \\
149^{\circ} 34^{\prime} 45^{*}\end{array}$ & do. & do. & $\begin{array}{l}\text { Echinoderm frognents, inciuding } \\
\text { peimatozoan columnals }\end{array}$ & $\begin{array}{l}\text { Ordovician } \\
\text { to Permian } \\
\text { or younger. }\end{array}$ & $\begin{array}{l}\text { d.T. Dutro in } \\
\text { Gllbert and } \\
\text { Redman, } 1977\end{array}$ & \\
\hline
\end{tabular}


Table 2. Fossil data from the Healy quadrangle, Alaska-Continued

\begin{tabular}{|c|c|c|c|c|c|c|c|}
\hline $\begin{array}{l}\text { Map No., } \\
\text { map unit, } \\
\text { quad. No. }\end{array}$ & $\begin{array}{l}\text { Location } \\
\text { lat (N.) and } \\
\text { long (W.) }\end{array}$ & $\begin{array}{l}\text { Fieid No. (s). } \\
\text { (USGS Museum No.), } \\
\text { and (or) collector }\end{array}$ & Lithology & Fossils & $\begin{array}{l}\text { Fossil } \\
\text { age }\end{array}$ & $\begin{array}{l}\text { Determiner } \\
\text { and (or) reference }\end{array}$ & Comments \\
\hline $\begin{array}{l}157 \\
\text { Dy } \\
\text { C-3 }\end{array}$ & $\begin{array}{l}63^{\circ} 34^{\prime} 56^{\prime \prime} \\
148^{\circ} 14^{\prime} 52^{\prime \prime}\end{array}$ & 82 AMM-29 & do. & $\begin{array}{l}\text { Conodonts: } \\
\text { Palmatolepis rugosa } \\
\text { trochytera } \\
\text { P. glabra pectinata } \\
\text { P. sp. }\end{array}$ & $\begin{array}{l}\text { Late } \\
\text { Devonian } \\
\text { (Middle } \\
\text { Famennian). }\end{array}$ & $\begin{array}{l}\text { M.W. Mullen, and } \\
\text { C.A. Sandberg, } \\
\text { this report }\end{array}$ & $\begin{array}{l}\text { Sample from thin marble } \\
\text { interbed in metavdcanic } \\
\text { sequence. Conodont speci- } \\
\text { mens were badly distorted. } \\
\text { CAI-6. }\end{array}$ \\
\hline $\begin{array}{l}158 \\
\text { DV } \\
\text { C-3 }\end{array}$ & $\begin{array}{l}63^{\circ} 34^{\prime} 00^{\prime \prime} \\
148^{\circ} 18^{\prime} 30^{\prime \prime} \\
\text { (general bc.) }\end{array}$ & $\begin{array}{l}81 \text { ACy-M5 } \\
81 \text { ACy-M6 } \\
81 \text { ACy-M9 }\end{array}$ & Chert & Barren of identifiable microfossils & No data & $\begin{array}{l}\text { C.D. Blome } \\
\text { written commun., } \\
1982 \text {. }\end{array}$ & Processed for radiolarians \\
\hline $\begin{array}{l}159 \\
\text { Dy } \\
\text { C-3 }\end{array}$ & $\begin{array}{l}63^{\circ} 33^{\prime} 10^{\prime \prime} \\
148^{\circ} 08^{\prime} 30^{\prime \prime} \\
\text { (general loc.) }\end{array}$ & $\begin{array}{l}81 \mathrm{ACn}-781 \text { and } \\
782\end{array}$ & do. & do. & do. & do. & Do. \\
\hline $\begin{array}{l}160 \\
\text { Dy } \\
\text { C-3 }\end{array}$ & $\begin{array}{l}63^{\circ} 33^{\prime} 40^{\prime \prime} \\
148^{\circ} 05^{\circ} 40^{\prime \prime} \\
\text { (general loc.) }\end{array}$ & 81 ACy-64, 65 & do. & do. & do. & $\begin{array}{l}\text { N.R.D. Albert, } \\
\text { written commun., } \\
1982 \text {. }\end{array}$ & Do. \\
\hline $\begin{array}{l}161 \\
\text { Dy } \\
\text { C-2 }\end{array}$ & $\begin{array}{l}63^{\circ} 37^{\prime} 58^{*} \\
147^{\circ} 56^{\prime} 54^{\prime \prime}\end{array}$ & $81 \mathrm{ACn}-763$ & do. & do. & do. & $\begin{array}{l}\text { C.D. Blome, } \\
\text { written commun., } \\
1982 \text {. }\end{array}$ & Do. \\
\hline $\begin{array}{l}162 \\
\text { Dy } \\
\text { C-2 }\end{array}$ & $\begin{array}{l}63^{\circ} 36^{\prime} 22^{n} \\
147^{\circ} 51^{\prime} 52^{\prime \prime}\end{array}$ & $81 \mathrm{AC} y-60$ & do. & do. & do. & do. & Do. \\
\hline $\begin{array}{l}163 \\
\text { Dy } \\
\text { C-2 }\end{array}$ & $\begin{array}{l}63^{\circ} 37^{\prime} 38^{\prime \prime} \\
147^{\circ} 45^{\prime} 50^{\prime \prime}\end{array}$ & $81 \mathrm{ACy}-32$ & do. & do. & do. & $\begin{array}{l}\text { N.R.D. Albert, } \\
\text { written commun., } \\
1982 \text {. }\end{array}$ & Do. \\
\hline $\begin{array}{l}164 \\
\text { DV } \\
C-2\end{array}$ & $\begin{array}{l}63^{\circ} 37^{\prime} 30^{\prime \prime} \\
147^{\circ} 38^{\prime} 44^{\prime \prime}\end{array}$ & $81 \mathrm{ACy}-62$ & do. & do. & do. & $\begin{array}{l}\text { C.D. Blome, } \\
\text { witten commun., } \\
1982 \text {. }\end{array}$ & Do. \\
\hline $\begin{array}{c}165 \\
\text { DOs(Is) } \\
\text { B-6 }\end{array}$ & $\begin{array}{l}63^{\circ} 25^{\prime} 10^{\prime \prime} \\
149^{\circ} 56^{\prime} 30^{\circ}\end{array}$ & 83 AMM-2 & Limestone & do. & do. & $\begin{array}{l}\text { M.W. Mullen, } \\
\text { this report. }\end{array}$ & $\begin{array}{l}\text { Processed for conodonts; } \\
\text { algal laminated limestone. }\end{array}$ \\
\hline $\begin{array}{l}166 \\
\text { DOs } \\
\text { B-6 }\end{array}$ & $\begin{array}{l}63^{\circ} 25^{\prime} 12^{\prime \prime} \\
149^{\circ} 50^{\prime} 08^{\prime \prime}\end{array}$ & $83 \mathrm{AMM}-4$ & do. & do. & do. & do. & $\begin{array}{l}\text { Processed for conodonts; } \\
\text { fine-grained carbonate in- } \\
\text { terbedded with argiflite. }\end{array}$ \\
\hline $\begin{array}{l}167 \\
\text { DOs } \\
\text { B-6 }\end{array}$ & $\begin{array}{l}63^{\circ} 24^{\prime} 32^{\prime \prime} \\
149^{\circ} 47^{\prime} 48^{\prime \prime}\end{array}$ & $83 \mathrm{AMM}-5$ & do. & $\begin{array}{l}\text { Barren of conodonts; contains } \\
\text { indeterminate radiolarians. }\end{array}$ & do. & do. & $\begin{array}{l}\text { Processed for conodonts; } \\
\text { dark-gray, thinly laminated } \\
\text { radiolarian-bearing lime- } \\
\text { stone. }\end{array}$ \\
\hline $\begin{array}{c}168 \\
\text { DOsils) } \\
\text { B-6 }\end{array}$ & $\begin{array}{l}62^{\circ} 25^{\prime} 56^{\prime \prime} \\
149^{\circ} 40^{\prime} 40^{\prime \prime}\end{array}$ & $83 \mathrm{AMM}-6$ & do. & $\begin{array}{l}\text { Barren of microfossils; } \\
\text { contains recrystalized coral, } \\
\text { bryozoan, brachiopod, and } \\
\text { gastropod fragments. }\end{array}$ & do. & do. & $\begin{array}{l}\text { Processed for conodonts: } \\
\text { massive-bedded, shallow- } \\
\text { water limestone. }\end{array}$ \\
\hline
\end{tabular}




\begin{tabular}{|c|c|c|c|c|c|c|}
\hline $\begin{array}{c}169 \\
\text { Dosils) } \\
\text { B-6 }\end{array}$ & $\begin{array}{l}63^{\circ} 28^{\prime} 20^{\prime \prime} \\
149^{\circ} 17^{\prime} 10^{\prime \prime} \\
\text { (approx. boc.) }\end{array}$ & $\begin{array}{l}\text { Fossils no. 3, } \\
\text { S.R. Capps, } 1919\end{array}$ & do. & $\begin{array}{c}\text { Corals: Heliophyllum sp. } \\
\text { Cladopora sp. } \\
\text { Striatopora } 5\end{array}$ & $\begin{array}{l}\text { Middle } \\
\text { Devonian. }\end{array}$ & $\begin{array}{l}\text { Edwin Kirk, } \\
\text { written commun.,1919; } \\
\text { Capps, 1932, p. } 255 .\end{array}$ \\
\hline $\begin{array}{l}170 \\
\text { DOs } \\
\text { B-5 }\end{array}$ & $\begin{array}{l}63^{\circ} 27^{\prime} 18^{\prime \prime} \\
149^{\circ} 03^{\prime} 54^{\prime \prime}\end{array}$ & $\begin{array}{l}80-S-504 \\
80-S-503\end{array}$ & do. & $\begin{array}{l}\text { 504: Gastropods } \\
\text { 503: Bivalves, gastropods }\end{array}$ & $\begin{array}{l}\text { Ordovician } \\
\text { to Devoni- } \\
\text { an; post- } \\
\text { Devonian(?). }\end{array}$ & $\begin{array}{l}\text { E. Y. Yochelson } \\
\text { and John Pojeta } \\
\text { in Jones and } \\
\text { others, } 1983 \text {. }\end{array}$ \\
\hline $\begin{array}{c}171 \\
\text { Pecp } \\
D-2\end{array}$ & $\begin{array}{l}63^{\circ} 49^{\prime} 35^{\circ} \\
147^{\circ} 53^{\circ} 25^{\circ} \\
\text { (approx loc) }\end{array}$ & $\begin{array}{l}\text { Unavailable, } \\
\text { John Dunbier }\end{array}$ & Marble & $\begin{array}{l}\text { Echinoderm clastic particles, } \\
\text { including crinoid fragments } \\
\text { and echinoid spine. }\end{array}$ & $\begin{array}{l}\text { Possibly } \\
\text { Ordovician } \\
\text { or younger. }\end{array}$ & $\begin{array}{l}\text { A.K. Armstrong } \\
\text { in Gilbert and } \\
\text { Bundtzen, } 1979 .\end{array}$ \\
\hline
\end{tabular}


U.S. Geological Survey Miscellaneous Investigations Series Map I-1961

Geology and geochronology of the Healy quadrangle, south-central Alaska; by Csejtey and others, 1992.

The items noted below are incorrect as printed.

Plate 1, Geologic map:

In NW corner of T. 18 S., R. 4 W., all exposed bedrock within the window of the Monahan thrust should be unit KJf.

In eastern part of T. 17 S., R. 2 E., uncolored area should be colored as unit Kcs.

Near SW corner of map, in T. 22 S., R. 13 W., label Dsb should have leaders into dark-colored thrust slivers above and below it.

Field numbers in potassium-argon age determination boxes starting with no. 35 through no. 53 should be one number less (that is 34, etc.); field number for box no. 55 in unit Tgr should read 53; field numbers for boxes no. 55 through no. 58 in unit TKgr should read one number less (that is 54 through 57).

Plate 1, Cross section $A-A^{\prime}$ :

Unit labeled "KJfk (=KJf)" just left of the McKinley fault of the Denali fault system should be labeled "KJfl (=KJf)".

The subsurface area of unit labeled "KJfl (=KJf)" to the right of the McKinley fault of the Denali fault system, and just right of the small unit of Tgr, should be the same color as unit KJfl just left of unit Tgr and above the surface.

\section{Pamphlet:}

Page 39, last reference in right-hand column should read: Walker, R.G., and Mutti, Emiliano, 1973, Turbidite facies and facies associations, ....

Page 45, footnote no. 4: analytical unit should read moles/gram $\times 10^{-10}$.

Page 60, Map no. 135: field no 77-J-14 should line up with "Chert clasts in conglomerate" in lithology column; sample number in brackets should read (9799-SD); conodont name should read Polygnathus cf. P.glaber. 